DOEIID-10930

February 2002

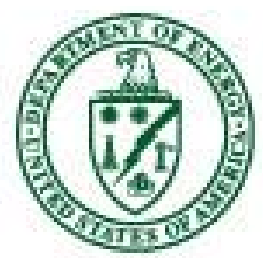

U.S. Department of Energy Idaho Operations Office

Annual INTEC Groundwater Monitoring Report for
Group 5 - Snake River Plain Aquifer (2001) 
DOE/ID-10930

Revision 0

\section{Annual INTEC Groundwater Monitoring Report for Group 5 - Snake River Plain Aquifer (2001)}

\section{Published February 2002}




\section{ABSTRACT}

This report describes the monitoring activities conducted and presents the results of groundwater sampling and water-level measurements from October 2000 to September 2001. Groundwater samples were initially collected from 41 wells from the Idaho Nuclear Technology and Engineering Center and the Central Facilities Area and analyzed for iodine-129, strontium-90, tritium, gross alpha, gross beta, technetium-99, uranium isotopes, plutonium isotopes, neptunium-237, americium-241, gamma spectrometry, and mercury. Samples from 41 wells were collected in April and May 2001. Additional sampling was conducted in August 2001 and included the two CFA production wells, the CFA point of compliance for the production wells, one well that was previously sampled and five additional monitoring wells.

Iodine-129 and strontium-90 were the only analytes above their respective maximum contaminant levels. Iodine- 129 was detected just above its maximum contaminant level of $1 \mathrm{pCi} / \mathrm{L}$ at two of the Central Facilities Area landfill wells. Iodine-129 was detected in the CFA production wells at $0.35 \pm 0.083 \mathrm{pCi} / \mathrm{L}$ in CFA-1, but was below detectable activity in CFA-2. Strontium-90 was above its maximum contaminant level of $8 \mathrm{pCi} / \mathrm{L}$ in several wells near the Idaho Nuclear Technology and Engineering Center but was below its maximum contaminant level in the downgradient wells at the Central Facilities Area landfills. Sr-90 was not detected in the CFA production wells. Gross beta results generally mirrored the results for strontium-90 and technetium-99.

Plutonium isotopes and neptunium-237 were not detected. Uranium-233/234 and uranium-238 isotopes were detected in all samples. Concentrations of background and site wells were similar and are within background limits for total uranium determined by the USGS, suggesting that the concentrations are background. Uranium-235/236 was detected in 11 samples, but all the detected concentrations were similar and near the minimum detectable activity. Americium-241 was detected at three locations near the minimum detectable activity of approximately $0.07 \mathrm{pCi} / \mathrm{L}$. The gamma spectrometry results detected cesium-137 in three samples, potassium-40 at eight locations, and radium-226 at one location. Mercury was below its maximum contaminant level of $2 \mu \mathrm{g} / \mathrm{L}$ in all samples. Gamma spectrometry results for the CFA production wells did not detect any analytes.

Water-level measurements were taken from wells in the Idaho Nuclear Technology and Engineering Center, Central Facilities Area, and the area south of Central Facilities Area to evaluate groundwater flow directions. Water-level measurements indicated groundwater flow to the south-southwest from the Idaho Nuclear Technology and Engineering Center. 


\section{CONTENTS}

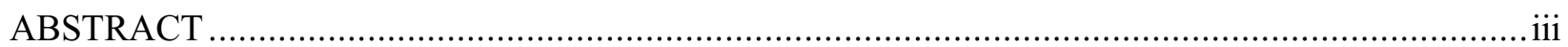

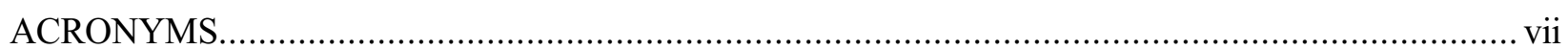

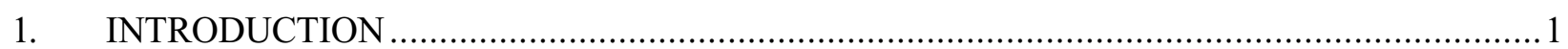

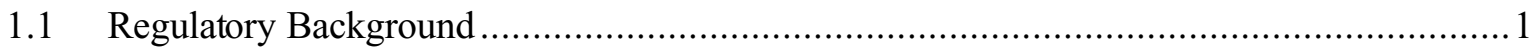

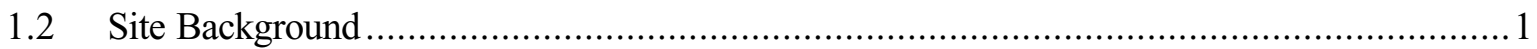

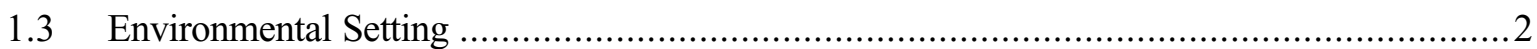

2. MONITORING PROGRAM AND RESULTS................................................................

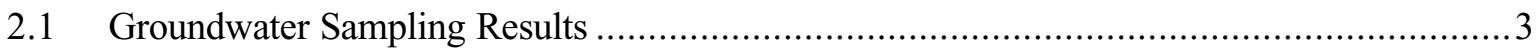

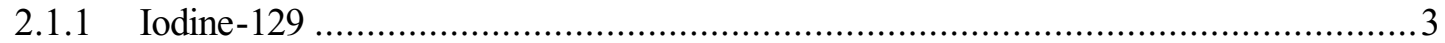

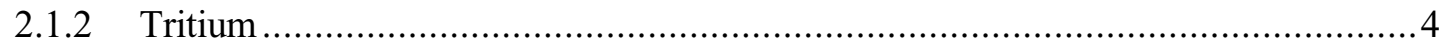

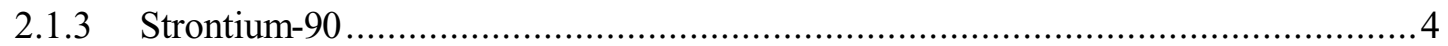

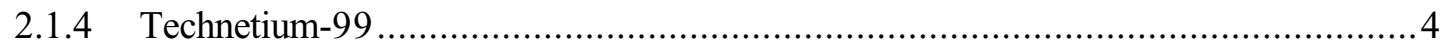

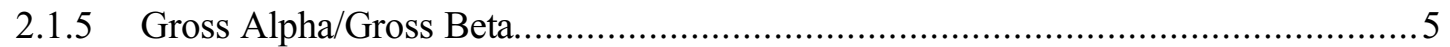

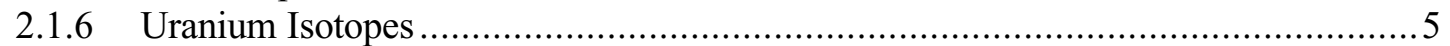

2.1.7 Plutonium Isotopes and Neptunium-237 f................................................... 5

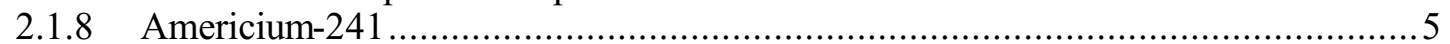

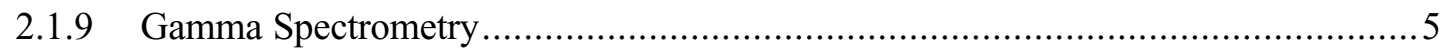

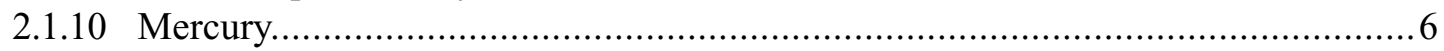

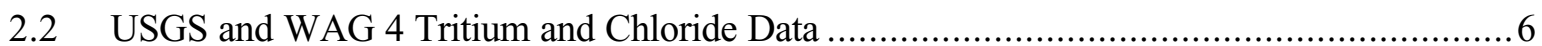

2.3 Monthly Water-Level Measurements........................................................................

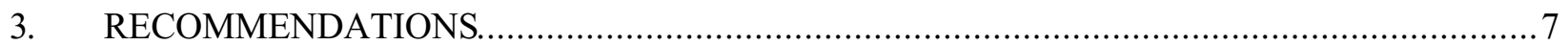

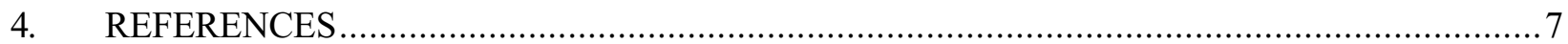

Appendix A-Water-Level Measurement Data and Borehole Deviation Correction Values

\section{FIGURES}

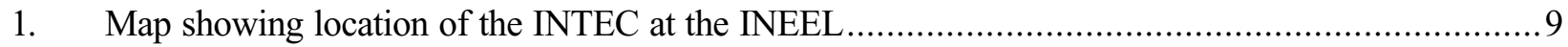

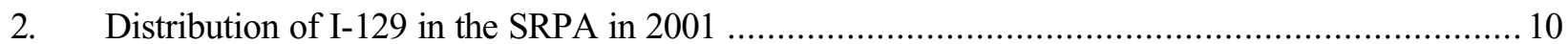


3. Iodine-129 concentration trends for select wells near INTEC ............................................. 11

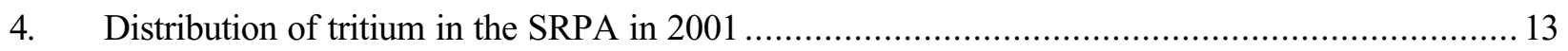

5. Tritium concentration trends for select wells near INTEC ............................................. 14

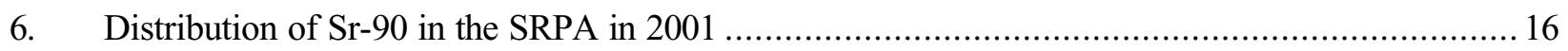

7. Strontium-90 concentration trends for select wells near INTEC......................................... 17

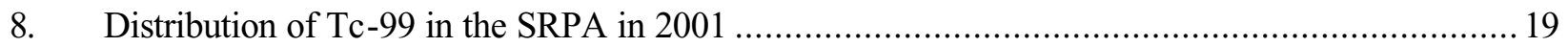

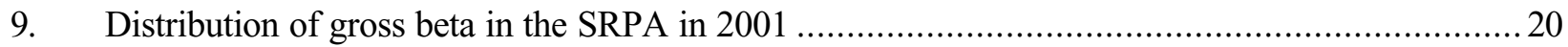

10. Distribution of chloride in the SRPA (USGS and WAG 4 data).........................................2

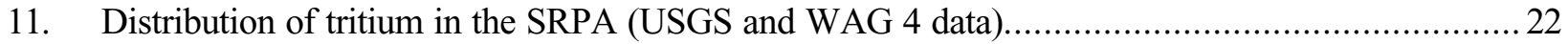

12. Hydrographs for select wells in the INTEC, CFA, RWMC, and STF areas............................23

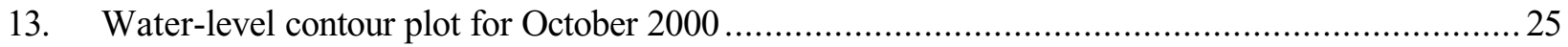

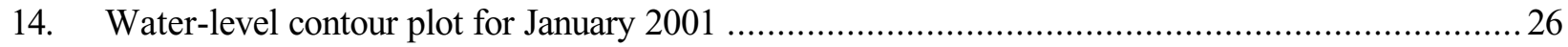

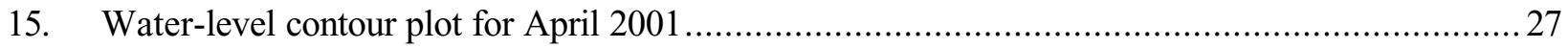

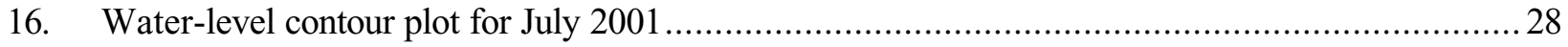

\section{TABLES}

1. Summary of iodine-129, Sr-90, tritium, Tc-99, gross alpha, and gross beta in the SRPA............ 29

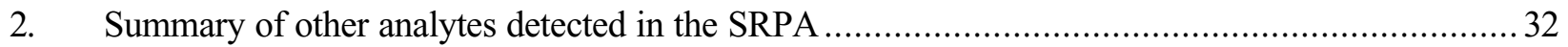

3. Summary of tritium and chloride data from USGS and WAG 4 sampling in 2000 .................. 34

A-1. Water-level measurements for September 2000 ....................................................

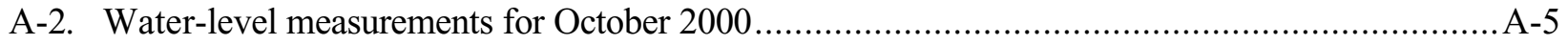

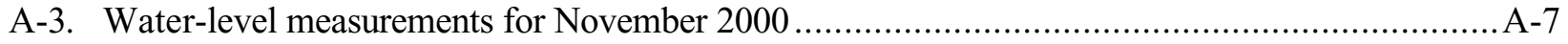

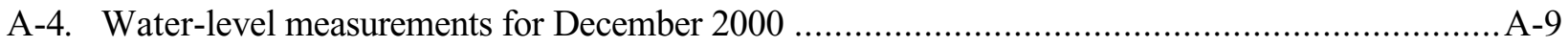

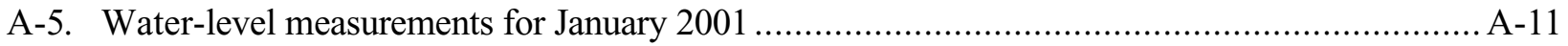

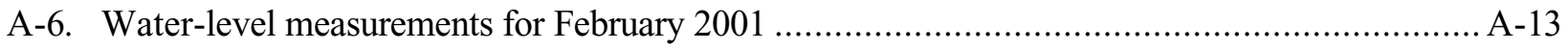

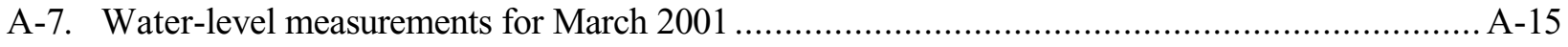

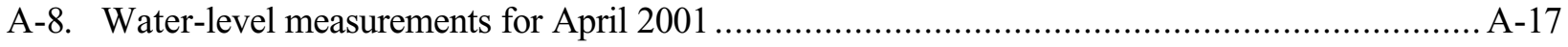


A-9. Water-level measurements for May 2001 ................................................................. A-19

A-10. Water-level measurements for June 2001 …................................................................. A-21

A-11. Water-level measurements for July 2001 ............................................................ A-23

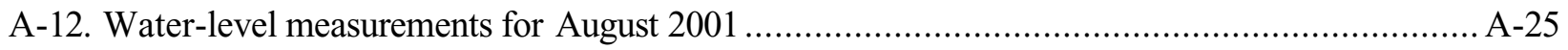




\section{ACRONYMS}

BC brass cap

BCC below brass cap

CERCLA Comprehensive Environmental Response, Compensation, and Liability Act

CFA Central Facilities Area

DOE Department of Energy

DOE-ID Department of Energy Idaho Operations Office

EPA Environmental Protection Agency

FFA/CO Federal Facility Agreement and Consent Order

FTAMSL feet above mean sea level

FTBMP feet below measuring point

ICPP Idaho Chemical Processing Plant

IDEQ Idaho Department of Environmental Quality

INEEL Idaho National Engineering and Environmental Laboratory

INTEC Idaho Nuclear Technology and Engineering Center

LTMP Long-Term Monitoring Plan

MCL maximum contaminant level

MDA minimum detectable activity

MSIP Monitoring System Installation Plan

NCP National Oil and Hazardous Substances Pollution Contingency Plan

OU operable unit

PBF Power Burst Facility

RI/FS remedial investigation/feasibility study

ROD Record of Decision

RWMC Radioactive Waste Management Complex

SARA Superfund Amendments and Reauthorization Act

SNF spent nuclear fuel

SRPA Snake River Plain Aquifer 
STF Security Training Facility

USGS United States Geological Study

WAG waste area group 


\section{Annual INTEC Groundwater Monitoring Report for Group 5 - Snake River Plain Aquifer (2001)}

\section{INTRODUCTION}

The purpose of this document is to report the groundwater sampling results and water-level measurements conducted to support the Waste Area Group (WAG) 3, Operable Unit (OU) 3-13, Group 5 - Snake River Plain Aquifer (SRPA) monitoring at the Idaho Nuclear Technology and Engineering Center (INTEC). The OU 3-13 Record of Decision (ROD) calls for Group 5 groundwater monitoring to monitor contaminant migration in the SRPA associated with the INTEC facility (DOE-ID 1999). The Long-Term Monitoring Plan (LTMP) (DOE-ID 2000a) specified the wells to be sampled and the parameters for analysis based on the data requirements identified in the ROD (DOE-ID 1999). The data quality objectives for the groundwater sampling are described in the Monitoring System Installation Plan (MSIP) (DOE-ID 2000b) and LTMP (DOE-ID 2000a).

\subsection{Regulatory Background}

The Idaho National Engineering and Environmental Laboratory (INEEL) is divided into 10 WAGs to manage environmental operations mandated under the Federal Facility Agreement and Consent Order (FFA/CO) (DOE-ID 1991). INTEC, formerly the Idaho Chemical Processing Plant (ICPP), is designated as WAG 3. OU 3-13 encompasses the entire INTEC facility.

In October 1999, the ROD was issued for OU 3-13, which includes the INTEC perched and groundwater systems (DOE-ID 1999). The remedial actions chosen in the ROD are in accordance with the Comprehensive Environmental Response, Compensation, and Liability Act (CERCLA) of 1980 (42 USC §9601) as amended by the Superfund Amendments and Reauthorization Act (SARA) of 1986 (42 USC 9601). In addition, remedies comply with the National Oil and Hazardous Substances Pollution Contingency Plan (NCP) (55 FR 8665) and are intended to satisfy the requirements of the FFA/CO.

The U.S. Department of Energy Idaho Operations Office (DOE-ID) is the lead agency for remedy decisions. The U.S. Environmental Protection Agency (EPA) Region 10 and the Idaho Department of Environmental Quality (IDEQ) approve these decisions.

\subsection{Site Background}

The INEEL is a government-owned facility managed by the United States Department of Energy (DOE). The eastern boundary of the INEEL is located $52 \mathrm{~km}$ (32 mi) west of Idaho Falls, Idaho. The INEEL Site occupies approximately $2,305 \mathrm{~km}^{2}\left(890 \mathrm{mi}^{2}\right)$ of the northwestern portion of the Eastern Snake River Plain in southeast Idaho. The INTEC facility covers an area of approximately $0.39 \mathrm{~km}^{2}\left(0.15 \mathrm{mi}^{2}\right)$ and is located approximately $72.5 \mathrm{~km}$ (45 mi) from Idaho Falls, in the south-central area of the INEEL as shown in Figure 1.

The INTEC has been in operation since 1952. The plant's original mission was to reprocess uranium from defense-related projects and to research and store spent nuclear fuel (SNF). The DOE phased out the reprocessing operations in 1992 and redirected the plant's mission to (1) receipt and temporary storage of SNF and other radioactive wastes for future disposition, (2) management of current and past wastes, and (3) performance of remedial actions. 
The liquid waste generated from the past reprocessing activities is stored in an underground tank farm. Numerous CERCLA sites are located in the area of the tank farm and adjacent to the process equipment waste evaporator. Contaminants found in the interstitial soils of the tank farm are the result of accidental releases and leaks from process piping, valve boxes, and sumps and from cross-contamination from operations and maintenance excavations. No evidence has been found to indicate that the waste tanks themselves have leaked. The contaminated soils at the tank farm comprise about $95 \%$ of the known contaminant inventory at INTEC. The comprehensive remedial investigation/feasibility studies (RI/FSs) for OU 3-13 (DOE-ID 1997a, 1997b, 1998) contain a complete discussion of the nature and extent of contamination.

\subsection{Environmental Setting}

The environmental setting is summarized here, and a complete description is given in DOE-ID (1997a), (1997b), and (1998). The SRPA underlies the INTEC and Eastern Snake River Plain and has been designated by the EPA as a sole source aquifer for the region. The aquifer lies at a depth of

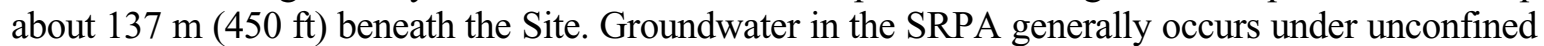
conditions, but locally may be quasi-artesian or artesian (Nace et al. 1959). Regional groundwater flow is southwest at average estimated velocities of $1.5 \mathrm{~m} /$ day $(5 \mathrm{ft} /$ day). The average groundwater flow velocity at the INTEC is estimated at $3 \mathrm{~m} /$ day ( $10 \mathrm{ft} /$ day) due to local hydraulic conditions. Hydraulic characteristics of the aquifer differ considerably from place to place depending on the saturated thickness and the characteristics of the basalts and sedimentary interbeds.

Recharge to the aquifer is primarily by valley underflow from the mountains to the north and northeast of the plain and from infiltration of irrigation water. A small amount of recharge occurs directly from precipitation. Recharge to the aquifer within INEEL boundaries is primarily by underflow from the northeastern part of the plain and the Big Lost River (Bennett 1990). Significant amounts of recharge from the Big Lost River have caused water levels in some wells at the INEEL to rise as much as $1.8 \mathrm{~m}$ (6 ft) within a few months after high flows in the river (Barraclough, Lewis, and Jensen 1982). Locally, the direction of groundwater flow is temporarily changed by recharge from the Big Lost River (Bennett 1990).

The source of contamination in the SRPA originates primarily from the injection well (CPP-23). However, contaminated soils and perched water are predicted to contribute to future SRPA contamination. The iodine-129 (I-129), strontium-90 (Sr-90), and plutonium isotopes were determined to be the only contaminants that pose an unacceptable risk to a hypothetical future resident beyond the year 2095. The primary I-129 source was the former injection well. The primary Sr-90 source(s) were the former injection well and the tank farm soils. The primary source of plutonium isotopes is the tank farm. The major human health threat posed by contaminated SRPA groundwater is exposure to radionuclides via ingestion by future groundwater users.

\section{MONITORING PROGRAM AND RESULTS}

The WAG 3, Group 5 monitoring activities consisted of groundwater sampling and taking waterlevel measurements. Water-level measurements were taken monthly from September 2000 through August 2001. Groundwater was sampled from 41 wells in April and May 2001. Additional groundwater sampling was conducted in August 2001 and included sampling the two Central Facilities Area (CFA) production wells, the point of compliance for the CFA production wells, and six monitoring wells. 


\subsection{Groundwater Sampling Results}

The LTMP called for sampling 47 wells near INTEC and to the south of the INTEC. Samples were collected from 41 of the 47 wells from April 23 to May 31, 2001. Wells LF 2-12, LF 3-09, USGS-122, USGS-49, MW-18, and LF 3-11 were not sampled because of problems with sampling pumps. Well LF 3-11 has been rendered unusable due to perforation of the screen and entrance of gravel pack and well seal material into the damaged screen. Well LF 3-11 will be replaced by a new well, USGS-128, when it is completed. USGS-128 and LF 3-11 are approximately 1300 feet east-northeast of USGS-85. The pump in LF 3-09 has been replaced and is functional, as of November 11, 2001. Well LF 2-12 was not sampled, but wells LF 2-09 and LF 2-08 are located close to this well and were sampled. Well maintenance for the USGS wells with pump problems will be done by the USGS. Well maintenance for MW-18 will be handled by the INEEL ER Program.

Groundwater samples were analyzed for tritium, Sr-90, I-129, uranium isotopes, plutonium isotopes, americium-241 (Am-241), mercury, gamma spectrometry, technetium-99 (Tc-99), and gross alpha/beta in accordance with the LTMP. The data analysis will focus on tritium, I-129, Tc-99, Sr-90, and gross beta since these parameters have plumes migrating from INTEC. The results for these five parameters are summarized in Table 1. The results for uranium isotopes, mercury, Am-241, and gamma spectrometry are summarized in Table 2 . All results are provided electronically in an attached 3.5-in. floppy disk.

After the results for the initial sampling were reviewed, it was apparent that contaminants from INTEC extended beyond the area sampled. To determine the impact of the INTEC plumes on the CFA production wells and to evaluate the migration of I-129, Sr-90, Tc-99, and tritium in the SRPA, additional sampling was conducted from August 28-30, 2001. Gamma spectrometry analysis was also performed on the CFA production wells. The wells in this sampling event included the two CFA production wells, the CFA point of compliance for the production wells (CFA-1606), CFA-MON-001, CFA-MON-002, and CFA-MON-003, USGS-127, LF 2-08 (resampled), and USGS-83. CFA production well CFA-1 has a screen interval from 444 to 639 feet below ground surface (bgs) and a pump depth of 576.5 feet. CFA production well CFA-2 is screened from 521 to 651 feet bgs and has a pump depth of 575.9 feet. The CFA point of compliance is located in CFA-1606 and is an above-ground sampling point that samples the CFA drinking water system after the water from CFA-1 and CFA-2 are mixed together.

\subsection{1 lodine-129}

The groundwater sampling results indicate that an I-129 plume extends from INTEC into the CFA area. The highest I-129 concentrations were detected in two wells at the CFA landfills (Figure 2). Only two wells, LF 3-8 (in the duplicate sample) and LF 2-8, had I-129 concentrations that exceeded the maximum contaminant level (MCL) of $1 \mathrm{pCi} / \mathrm{L}$. The minimum detectable activity (MDA) for I-129 was approximately $0.1 \mathrm{pCi} / \mathrm{L}$. In contrast, I-129 was over $1 \mathrm{pCi} / \mathrm{L}$ in 12 wells in the 1991 groundwater sampling event. The two wells that had the highest I-129 concentrations in 1991, USGS-112 and USGS-113, were below the MDA in the latest round. Iodine-129 was detected at $0.352 \pm 0.083 \mathrm{pCi} / \mathrm{L}$ in CFA-1 (a CFA production well) but I-129 was not detected in CFA-2, which is the other CFA production well and was near the detection limit $(0.098 \pm 0.053 \mathrm{pCi} / \mathrm{L})$ at the CFA point of compliance (CFA-1606). Iodine-129 was not detected in the wells sampled south of the CFA.

Trend analysis of the I-129 data indicates that I-129 is decreasing at most locations except at CFA-1 which does not show a distinct trend (Figure 3). Trend analysis for I-129 is hindered by the lack of data from 1990 to 2001. Iodine-129 data were collected in 1995, but this data had a much higher MDA of approximately 0.5 to $1 \mathrm{pCi} / \mathrm{L}$. 


\subsubsection{Tritium}

The tritium results indicated a plume extending from INTEC, past the CFA landfill wells and beyond CFA-MON-A-002 (Figure 4). The extent of the tritium plume is similar to that previously determined using United States Geological Study (USGS) and WAG 4 data and is discussed below. The highest tritium concentration was $14,000 \pm 771 \mathrm{pCi} / \mathrm{L}$ at USGS-114, and all wells were below the MCL of $20,000 \mathrm{pCi} / \mathrm{L}$. The MDA for tritium was 300 to $400 \mathrm{pCi} / \mathrm{L}$. Overall, the tritium results from this sampling event were considerably lower than the results from the 1995 sampling presented in the RI/FS (DOE-ID 1997a). Tritium was detected at 7,900 and 9,200 pCi/L in the CFA production wells. Tritium was detected at concentrations of less than $1,700 \mathrm{pCi} / \mathrm{L}$ in the CFA MON wells, but was not detected in USGS-83 to the south and USGS-127 to the west of the CFA-MON wells.

An anomaly in the recent sampling is that the tritium concentration in USGS-20 was $6,090 \pm 359 \mathrm{pCi} / \mathrm{L}$ whereas tritium was not detected in 1995 and was not detected in USGS sampling in July $2000(\mathrm{MDA} \approx 300$ to $400 \mathrm{pCi} / \mathrm{L})$. The significance of the tritium occurrence at USGS-20 is uncertain, but other analytes indicative of contamination from INTEC such as I-129, Tc-99, or Sr-90 are not present.

Trend analysis of data since 1985 indicates that tritium is decreasing at all locations (Figure 5). Most of the data shown for select wells within the tritium plume on Figure 5 is from USGS sampling. Except for USGS-47, a consistent downtrend in tritium concentrations is indicated by the negative slope of the correlation lines and correlation coefficients $\left(\mathrm{R}^{2}\right)$ greater than 0.85 .

\subsubsection{Strontium-90}

Sr-90 was detected at 31 well locations with the highest $\mathrm{Sr}-90$ concentration, $45.0 \pm 7.57 \mathrm{pCi} / \mathrm{L}$, occurring at USGS-47. The minimum detectable activity for Sr-90 was typically between 0.25 to $0.45 \mathrm{pCi} / \mathrm{L}$ for the samples collected in April and May and approximately $0.6 \mathrm{pCi} / \mathrm{L}$ for samples collected in August. The MCL for Sr-90 is $8 \mathrm{pCi} / \mathrm{L}$. The distribution of Sr-90 in the SRPA indicated a plume extending south of INTEC to the CFA landfills (Figure 6). Sr-90 was below detection limits of approximately $0.5 \mathrm{pCi} / \mathrm{L}$ in the CFA production wells. The area of the SRPA exceeding the 8-pCi/L limit for $\mathrm{Sr}-90$ is similar in size to the area above $8 \mathrm{pCi} / \mathrm{L}$ in 1995 . An increase in $\mathrm{Sr}-90$ activity did occur at LF 3-08 located at CFA Landfill III. The increase in Sr-90 at LF 3-08 suggests that the Sr-90 plume axis is to the west of the CFA production wells.

Trend analysis of six wells within the Sr-90 plume indicates that Sr-90 is steadily decreasing at most locations, except USGS-47, which does not show a distinct trend (Figure 7). For the wells that show a trend, the slope of the regression lines is negative and the correlation coefficients are greater than 0.66 for all wells. Most of the data shown on Figure 7 is from USGS sampling.

\subsubsection{Technetium-99}

Tc-99 was detected in 20 of the 41 samples with the highest level, $322 \pm 6.6 \mathrm{pCi} / \mathrm{L}$, occurring at USGS-52. The highest Tc-99 concentration occurred at the same location as the highest gross beta concentration. The minimum detectable activity for Tc-99 was typically 5 to $6 \mathrm{pCi} / \mathrm{L}$. All sample results are below the calculated MCL of $900 \mathrm{pCi} / \mathrm{L}$. Tc-99 was detected in the CFA landfill wells at levels ranging from $7.68 \pm 1.71$ to $15.6 \pm 1.92 \mathrm{pCi} / \mathrm{L}$. Tc-99 was detected in CFA-1 at $8.8 \pm 4.9 \mathrm{pCi} / \mathrm{L}$ and in CFA-MON-002 south of CFA at 5.28 $\pm 2.8 \mathrm{pCi} / \mathrm{L}$. The distribution of Tc-99 in the SRPA is shown on Figure 8 . 


\subsubsection{Gross Alpha/Gross Beta}

Gross alpha was above its MDA (approximately 1.8 to $3 \mathrm{pCi} / \mathrm{L}$ ) at 14 of 41 well locations with detections ranging from 2.2 to $15 \mathrm{pCi} / \mathrm{L}$. The highest gross alpha level occurred in USGS-52 and it was the only well at the MCL. The MCL for gross alpha is $15 \mathrm{pCi} / \mathrm{L}$.

Gross beta was above its MDA (typically 3 to $4 \mathrm{pCi} / \mathrm{L}$ ) at 36 of 41 well locations and results varied from $4.25 \pm 1.26$ to $151 \pm 8.42 \mathrm{pCi} / \mathrm{L}$. The highest gross beta level occurred at USGS-52 and it was the only well at the MCL. The MCL for gross beta is $4 \mathrm{mrem} / \mathrm{yr}$. The distribution of gross beta in the SRPA shows an area above $50 \mathrm{pCi} / \mathrm{L}$ extending from INTEC south to beyond USGS-112 (Figure 9). The gross beta results generally correlate with the Sr-90 and Tc-99 results (see Table 1).

\subsubsection{Uranium Isotopes}

Uranium-233/234 (U-233/234) was above the minimum detectable activity $(0.02$ to $0.1 \mathrm{pCi} / \mathrm{L})$ in all samples. The range of $U-233 / 234$ detected was from $0.646 \pm 0.118$ to $1.67 \pm 0.153 \mathrm{pCi} / \mathrm{L}$. The narrow range of detection and the occurrence of $1.57 \pm 0.147 \mathrm{pCi} / \mathrm{L}$ in the upgradient well, USGS-121, suggests that the occurrence of $\mathrm{U}-233 / 234$ is natural. Similarly, U-238 was above the MDA $(0.05$ to $0.1 \mathrm{pCi} / \mathrm{L})$ at all locations with a range from 0.252 to $0.851 \mathrm{pCi} / \mathrm{L}$ and the upgradient well, USGS-121, contained $0.619 \pm 0.074 \mathrm{pCi} / \mathrm{L}$. The narrow range of detections and a background concentration similar to site and downgradient data suggest that the U-238 occurrences are natural. In addition, the concentrations of U-233/234 and U-238 are consistent with background concentrations for total uranium in groundwater in Idaho of 0 to $9 \mathrm{pCi} / \mathrm{L}$ (Orr, Cecil, and Knobel 1991).

$\mathrm{U}-235 / 236$ was above the MDA at 18 locations and ranged in concentration from $0.0277 \pm 0.12 \mathrm{pCi} / \mathrm{L}$ to $0.146 \pm 0.057 \mathrm{pCi} / \mathrm{L}$. The highest concentration of $\mathrm{U}-235 / 236$ occurred at location USGS-35. All the detections of U-235/236 were close to the MDA (0.02 to $0.1 \mathrm{pCi} / \mathrm{L})$.

\subsubsection{Plutonium Isotopes and Neptunium-237}

Plutonium isotopes and neptunium-237 were not detected at any of the sampling locations. The minimum detectable activity for neptunium- 237 was from 0.06 to $0.13 \mathrm{pCi} / \mathrm{L}$. The MDAs for plutonium-238, plutonium-239/240 and plutonium-241 were 0.028 to $0.07 \mathrm{pCi} / \mathrm{L}, 0.02$ to $0.08 \mathrm{pCi} / \mathrm{L}$, and 7 to $10 \mathrm{pCi} / \mathrm{L}$, respectively.

\subsubsection{Americium-241}

Am-241 was detected at LF $2-8$ at $0.0742 \pm 0.0336 \mathrm{~J} \mathrm{pCi} / \mathrm{L}$ and at ICPP-MON-A-021 at $0.0733 \pm 0.0331 \mathrm{~J} \mathrm{pCi} / \mathrm{L}$ and USGS-20 at $0.0472 \pm 0.0191 \mathrm{~J} \mathrm{pCi} / \mathrm{L}$. The $\mathrm{J}$ flag associated with these Am-241 occurrences indicates that the values are estimated. The MDA was typically 0.02 to $0.08 \mathrm{pCi} / \mathrm{L}$, but was over $0.15 \mathrm{pCi} / \mathrm{L}$ for a few samples. All of the Am-241 detections were close to the MDA.

\subsubsection{Gamma Spectrometry}

The gamma spectrometry analysis for the 41 wells sampled in April-May 2001 detected cesium-137 (Cs-137), potassium-40 (K-40), radium-226 (Ra-226), and zinc-65 (Zn-65) (Table 2). No analytes were detected in the gamma spectrometry analysis of the water from the CFA production wells collected in August 2001.

The list of analytes included in the gamma spectrometry analysis includes antimony-125; cerium-144; Cs-134 and -137; cobalt-58 and -60; europium-152, -154, and -155; manganese-54; niobium-95; potassium-40; radium-226; ruthenium-103 and -106; silver-108 and -110; zinc-65; zirconium- 95 and isotopes greater than $2 \sigma$ and greater than the MDA. The minimum detectable activity 
for most of the above radionuclides was approximately 3 to $10 \mathrm{pCi} / \mathrm{L}$. The MDA for Cs-137 was approximately 3 to $4 \mathrm{pCi} / \mathrm{L}$, but the MDA for $\mathrm{K}-40$ was 25 to $40 \mathrm{pCi} / \mathrm{L}$ and the MDA for Ce- 144 was approximately $20 \mathrm{pCi} / \mathrm{L}$. The MDAs for Ra-226 and Zn-65 were typically between 6 and $10 \mathrm{pCi} / \mathrm{L}$.

Cs-137 was detected at USGS-40, USGS-41, and USGS-47 at levels of 9.25 $\pm 2.52,8.41 \pm 1.97$, and 10.6 $\pm 2.51 \mathrm{pCi} / \mathrm{L}$, respectively. K-40 was detected at nine locations: LF 2-8, LF 3-10, USGS-37 (K-40 was not detected in the duplicate sample from this well.), USGS-40, USGS-67, USGS-46, USGS-51, USGS-57, and USGS-116. The K-40 concentrations ranged from $34.3 \pm 10.4 \mathrm{pCi} / \mathrm{L}$ at USGS-51 to $68.9 \pm 18.1 \mathrm{pCi} / \mathrm{L}$ at USGS-40. Ra-226 was detected at USGS-85 at $4.61 \pm 1.44 \mathrm{pCi} / \mathrm{L}$. Zn-65 was detected at $5.25 \pm 1.16 \mathrm{pCi} / \mathrm{L}$ in the rinsate sample.

\subsubsection{Mercury}

The highest detected mercury concentration was $0.36 \mu \mathrm{g} / \mathrm{L}$ at USGS-44. The detection limit for mercury was $0.1 \mu \mathrm{g} / \mathrm{L}$. The MCL for mercury is $2 \mu \mathrm{g} / \mathrm{L}$. Mercury was detected near its detection limit of $0.1 \mu \mathrm{g} / \mathrm{L}$ in several of the CFA landfill wells, but mercury was also detected in a rinsate sample at the same concentration in the same analysis batch.

\subsection{USGS and WAG 4 Tritium and Chloride Data}

USGS and WAG 4 data for tritium and chloride were used to evaluate the migration path of the plumes from INTEC because the USGS data and WAG 4 data extend beyond the area covered in the Group 5 groundwater sampling. Data from April to October of 2000 were used to construct plume maps for chloride and tritium (Table 3 and Figures 10 and 11, respectively). The MDA for tritium was approximately 300 to $400 \mathrm{pCi} / \mathrm{L}$. The tritium and chloride maps indicate that CFA-MON-A-002 and CFA-MON-A-003 may have been impacted by contamination migrating from INTEC. The data from these maps were used to select wells CFA-MON-A-001 through CFA-MON-A-003, USGS-127, and USGS-83 to be sampled for I-129, Sr-90, Tc-99, and tritium to track the progress of those plumes. Locations USGS-84 and M12S have tritium concentrations of over 1,000 pCi/L, but the chloride levels in these wells are similar to background, suggesting that the source of tritium in these wells is not the INTEC. Well M12S is the first well downgradient of the CFA landfills to the southwest.

\subsection{Monthly Water-Level Measurements}

Water-level measurements were taken monthly from September 2000 to August 2001 for select wells in the INTEC, CFA, Power Burst Facility (PBF), and Radioactive Waste Management Complex (RWMC) area to determine the direction of groundwater movement. The area encompassed by water-level measurements was expanded from the area covered in the LTMP because of the flat gradient in the vicinity of INTEC and the need to include the area of the INTEC groundwater plumes. Several wells in the vicinity of INTEC that were originally proposed for water-level measurement in the LTMP, including USGS-40, -41, -42, -43, -44, -45, -46, -47, -48, -49, -52, -59, MW-18, ICPP-MON-A-021, and ICPP-MON-A-022, were not used for water-level measurements because these wells were grouped in INTEC and did not provide the spatial coverage needed to determine flow directions from INTEC. The list of wells measured each month sometimes changed because of access problems.

The depth to groundwater was determined using surveyed measuring point elevations and well deviation correction factors. Water-level measurements were adjusted for borehole deviation using USGS correction factors that are based on gyroscopic and/or magnetic deviation surveys. Borehole deviation data, either photogyroscopic, magnetic, or digital gyroscopic, are available for all but five wells used to construct the water-level maps. Borehole deviation data were not available for South-Mon-A-001 through -004 (M11S, M12S, M13S, and M14S) and USGS-107. Water-level measurements taken at wells with 
less than $0.3 \mathrm{ft}$ of vertical deviation from the true depth were not adjusted for deviation because deviation measurements have an uncertainty associated with them. For instance, the photogyroscopic surveys can have from 0.11 to $0.42 \mathrm{ft}$ of uncertainty depending on whether the high- or low-angle tool was used. The water-level measurement data and borehole deviation correction values are presented in Appendix A in Tables A-1 to A-12.

Hydrographs for selected wells in INTEC, CFA, RWMC, and the Security Training Facility (STF) show a trend of declining water levels over the 1-year period that water-level measurements were taken (Figure 12). Water-level elevations range from 1,438 $\mathrm{m}(4,459 \mathrm{ft})$ above median sea level in the northern part of the INTEC to about $1,428 \mathrm{~m}(4,428 \mathrm{ft})$ above median sea level near the RWMC.

Groundwater-level contour maps are plotted quarterly for October 2000, January 2001, April 2001, and July 2001 (Figures 13 through 16). The general direction of groundwater flow from INTEC is south to southwest. At CFA, the flow is southeast to southwest. The hydrographs and water-level contour maps show that water levels declined over the 1-year period, but the direction of groundwater flow remained the same throughout the year (see Figures 13 through 16). The groundwater flow directions indicated by the groundwater contour maps generally agree with the plume geometries for tritium and chloride, and this should be the case because both tritium and chloride act as conservative tracers for the groundwater flow.

The groundwater gradient in the area covered by the water-level measurements varies considerably (see Figures 13 through 16). The gradient is slight over the area between INTEC and CFA landfills (more than a mile) with less than $2 \mathrm{ft}$ of head difference. Steeper gradients are present south of CFA, near the $\mathrm{RWMC}$, and in the vicinity of the PBF. There is approximately $14 \mathrm{ft}$ difference in groundwater elevation from M12S to M13S ( $1 \mathrm{mi})$ near the RWMC and approximately $17.5 \mathrm{ft}$ from PBF-MON-A-001 to PBF-MON-A-004 over a distance of approximately $1 \mathrm{mi}$ at the PBF.

\section{RECOMMENDATIONS}

Well LF 2-08 should replace USGS-112 or USGS-113 in the list of wells for long-term monitoring (DOE-ID 2000a). LF 2-08 is at the MCL for I-129 and is close to the production well CFA-1 and changes in concentration of contaminants of interest, such as I-129, Sr-90, etc., would give an indication of the potential impacts on the CFA production wells.

The Site-Wide Drinking Water Program (SWDWP) has initiated the monitoring of the CFA drinking water system for I-129. This information will be collected quarterly during 2002 by the SWDWP. The information will be included in the annual Group 5 monitoring report and trended.

\section{REFERENCES}

55 FR 8665, 1990, "National Oil and Hazardous Substances Pollution Contingency Plan, Final Rule," Environmental Protection Agency, Federal Register, March 8, 1990.

42 USC 9601 et seq., 1986, The Superfund Amendments and Reauthorization Act (SARA), United States Code.

42 USC 9601 et seq., 1980, Comprehensive Environmental Response, Compensation, and Liability Act, United States Code.

Barraclough J. T., B. D. Lewis, and R. G. Jensen, 1982, "Hydrologic Conditions at the Idaho National Engineering Laboratory, Idaho - Emphasis: 1974-1978," U.S. Geological Survey Water-Supply Paper 2191, 1982, $52 \mathrm{p}$. 
Bennett, C. M., 1990, Streamflow Losses and Groundwater Level Changes along the Big Lost River at the INEL, Idaho, USGS Water Resources Investigation Report 86-4204, DOE/ID-22091, 1990.

DOE-ID, 2000a, Long-Term Monitoring Plan for Operable Unit 3-13, Group 5, Snake River Plain Aquifer, DOE/ID-10783, Rev. 1, U.S. Department of Energy Idaho Operations Office, November 2000.

DOE-ID, 2000b, Monitoring System and Installation Plan for Operable Unit 3-13, Group 5, Snake River Plain Aquifer, DOE/ID-10782, Rev. 1, U.S. Department of Energy Idaho Operations Office, November 2000.

DOE-ID, 1999, Final Record of Decision Idaho Nuclear Technology and Engineering Center, Operable Unit 3-13, DOE/ID-10660, Rev. 0, U.S. Department of Energy Idaho Operations Office, October 1999.

DOE-ID, 1998, Comprehensive RI/FS for the Idaho Chemical Processing Plant OU 3-13 at the INEEL-Part B, FS Supplement Report, DOE/ID-10619, Rev. 2, U.S. Department of Energy Idaho Operations Office, October 1998.

DOE-ID, 1997a, Comprehensive RI/FS for the Idaho Chemical Processing Plant OU 3-13 at the INEEL-Part A, RI/BRA Report (Final), DOE/ID-10534, Rev. 0, U.S. Department of Energy Idaho Operations Office, November 1997.

DOE-ID, 1997b, Comprehensive RI/FS for the Idaho Chemical Processing Plant OU 3-13 at the INEEL-Part B, FS Report (Final), DOE/ID-10572, Rev. 0, U.S. Department of Energy Idaho Operations Office, November 1997.

DOE-ID, 1991, Federal Facility Agreement and Consent Order for Idaho National Engineering Laboratory, U.S. Department of Energy Idaho Operations Office, U.S. Environmental Protection Agency Region 10, and State of Idaho Department of Health and Welfare, 1088-06-29-120, December 1991.

Nace, R. L. et al., 1959, Geography, Geology, and Water Resources of the National Reactor Testing Station, Idaho, Part 3, Hydrology and Water Resources, IDO-22034-USGS, United States Geological Survey, 1959.

Orr, B. R., L. D. Cecil, and L. L. Knobel, 1991, Background Concentrations of Selected Radionuclides, Organic Compounds, and Chemical Constituents in Ground Water in the Vicinity of the Idaho National Engineering Laboratory, Water-Resources Investigations Report 91-4015, DOE/ID-22094, United States Geological Survey, in cooperation with U.S. Department of Energy, February 1991. 


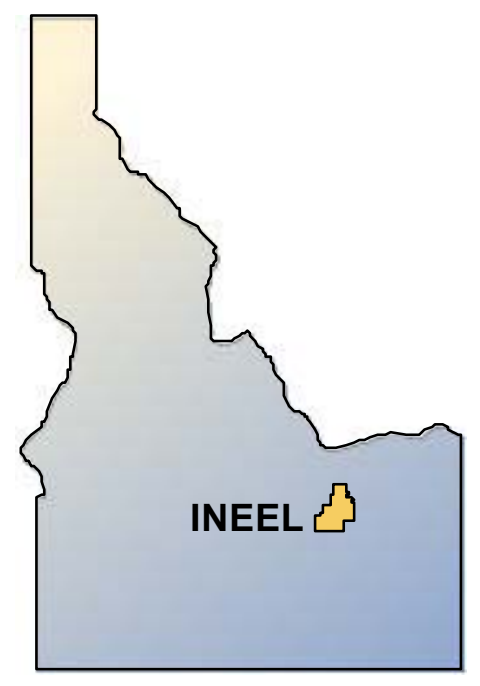

IDAHO

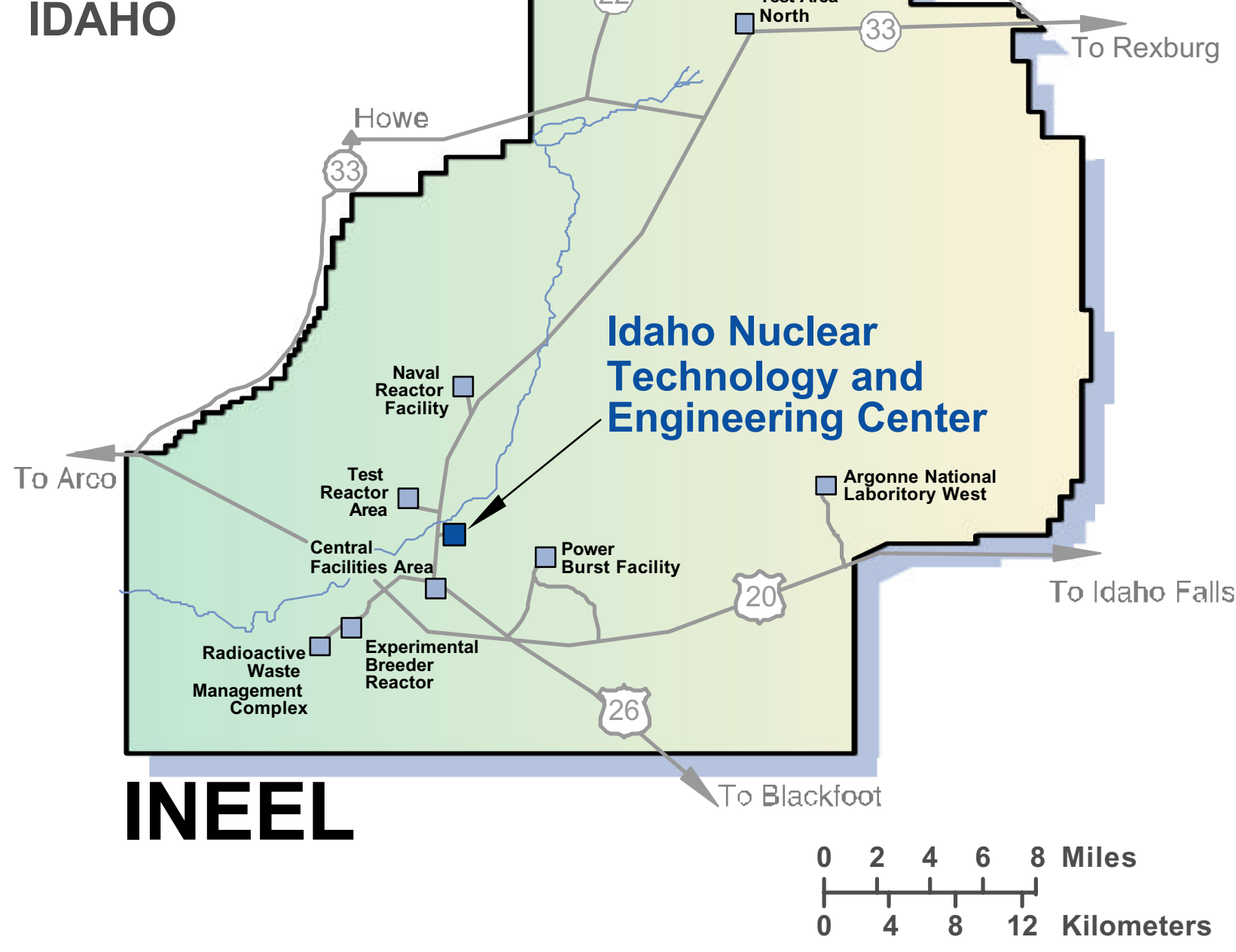

Figure 1. Map showing location of the INTEC at the INEEL. 


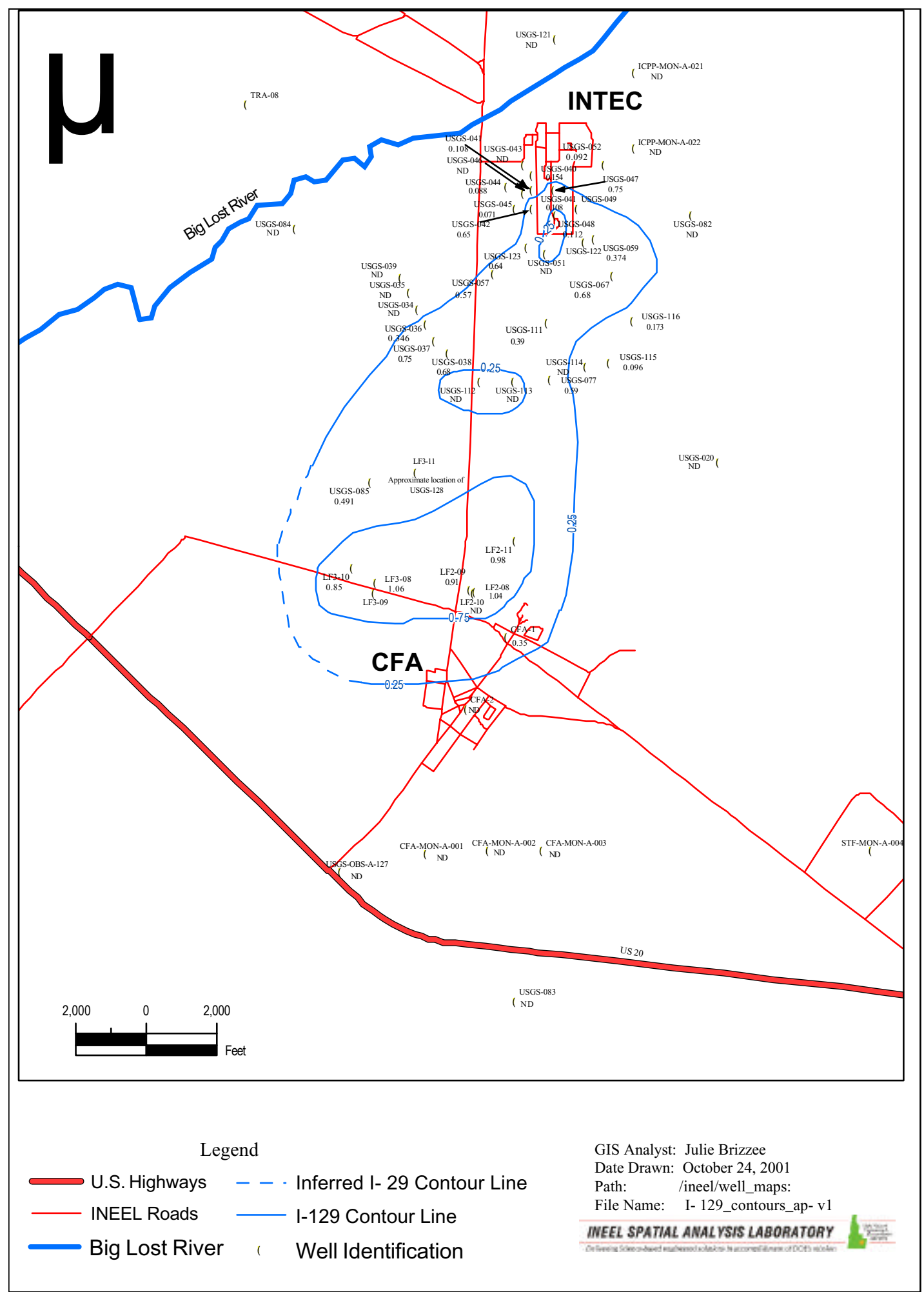

Figure 2. Distribution of I-129 in the SRPA in 2001. 
CFA-1

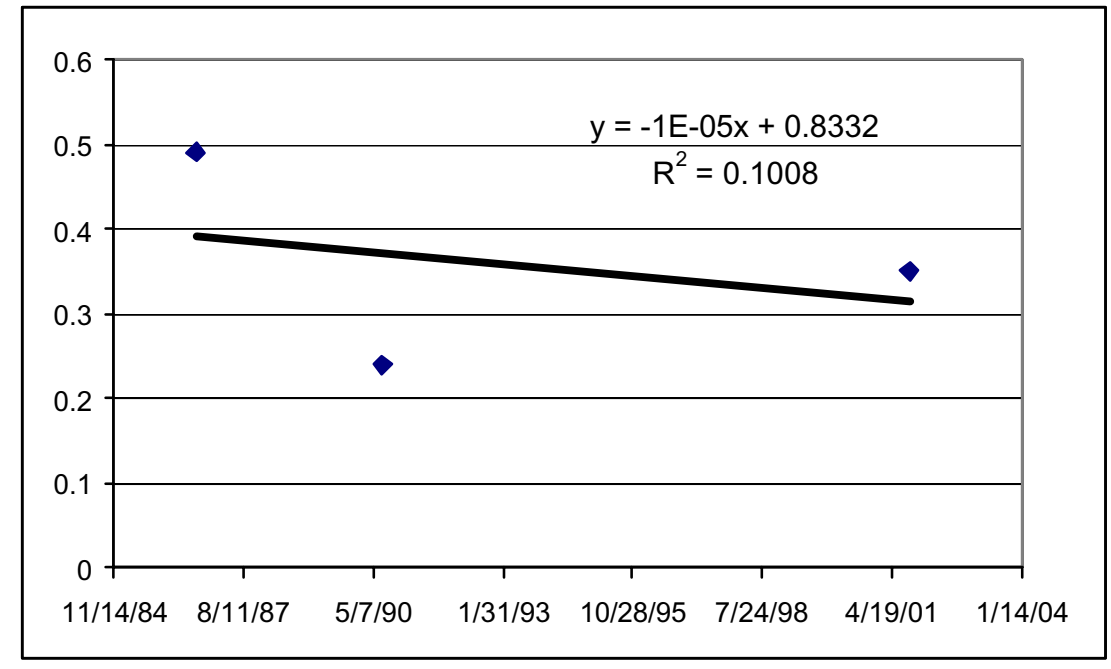

USGS-67

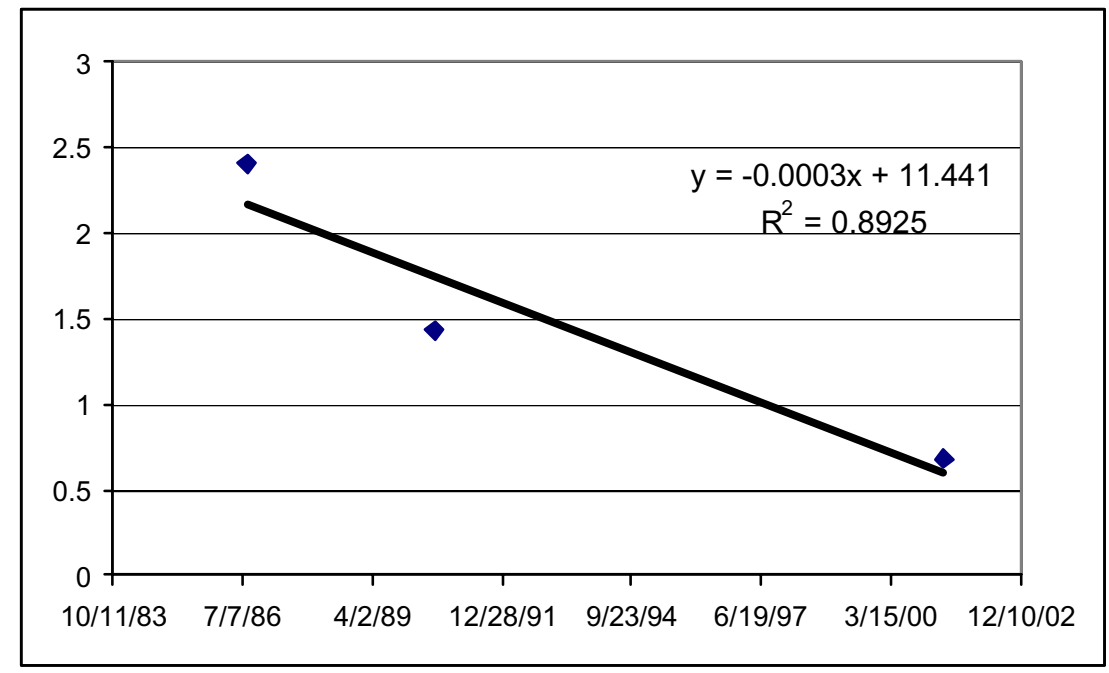

USGS-85

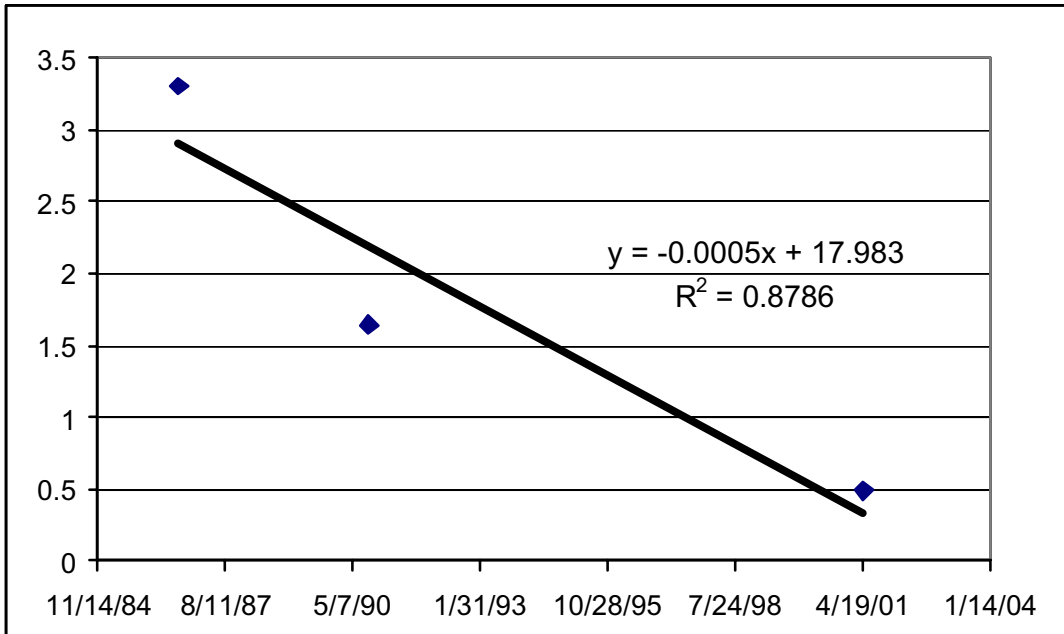

Figure 3. Iodine-129 concentration trends for select wells near INTEC. 
USGS-112

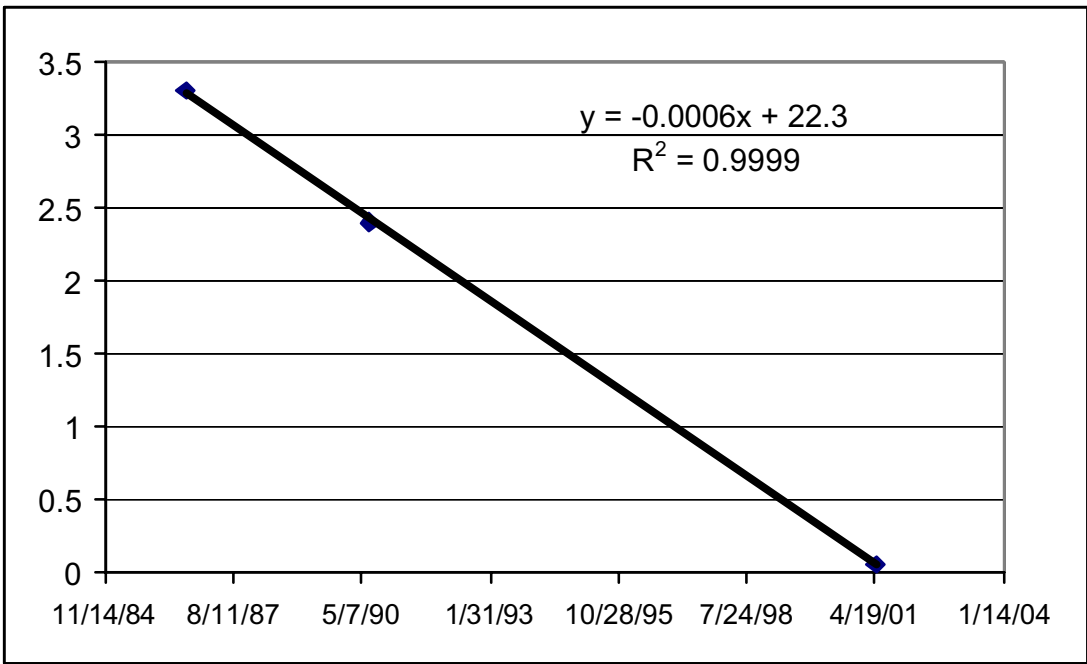

USGS-57

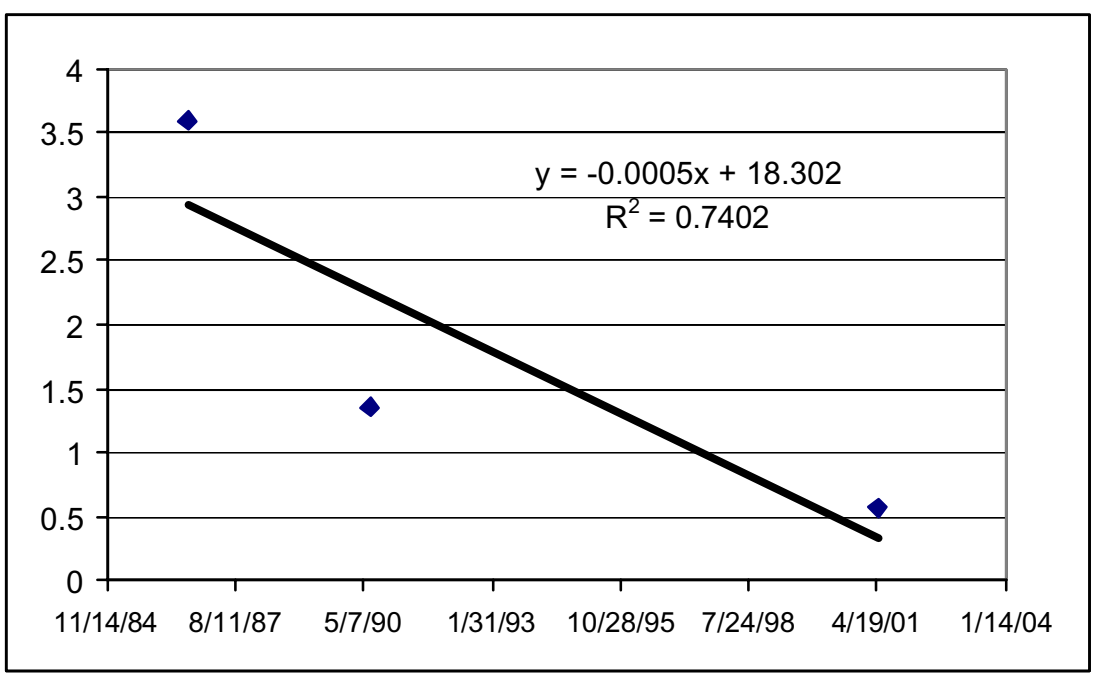

USGS-47

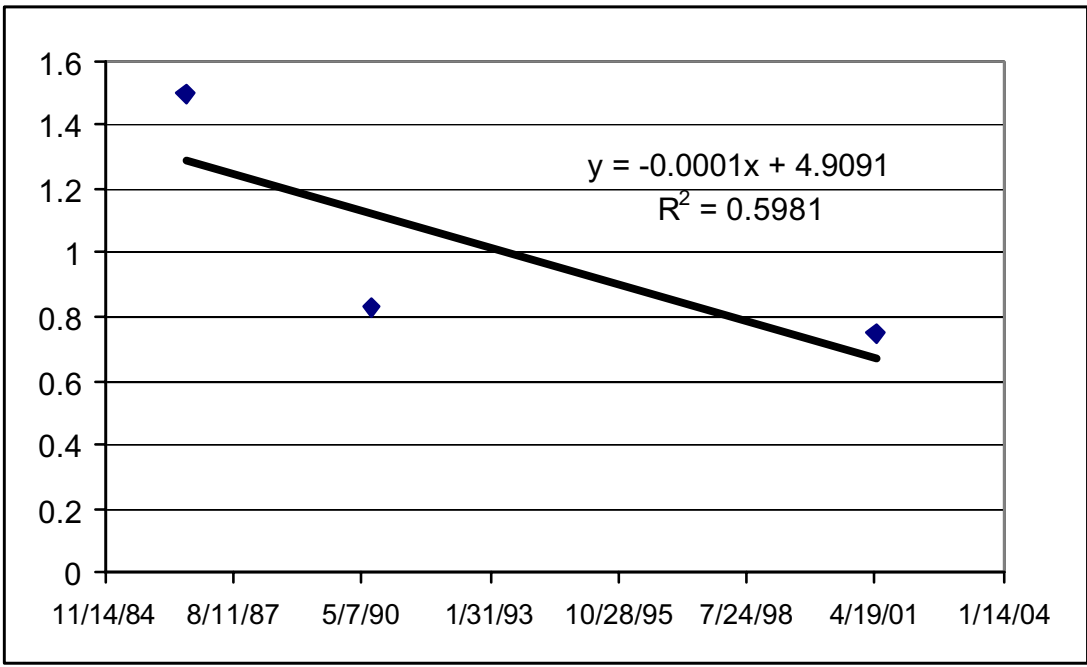

Figure 3. (continued). 


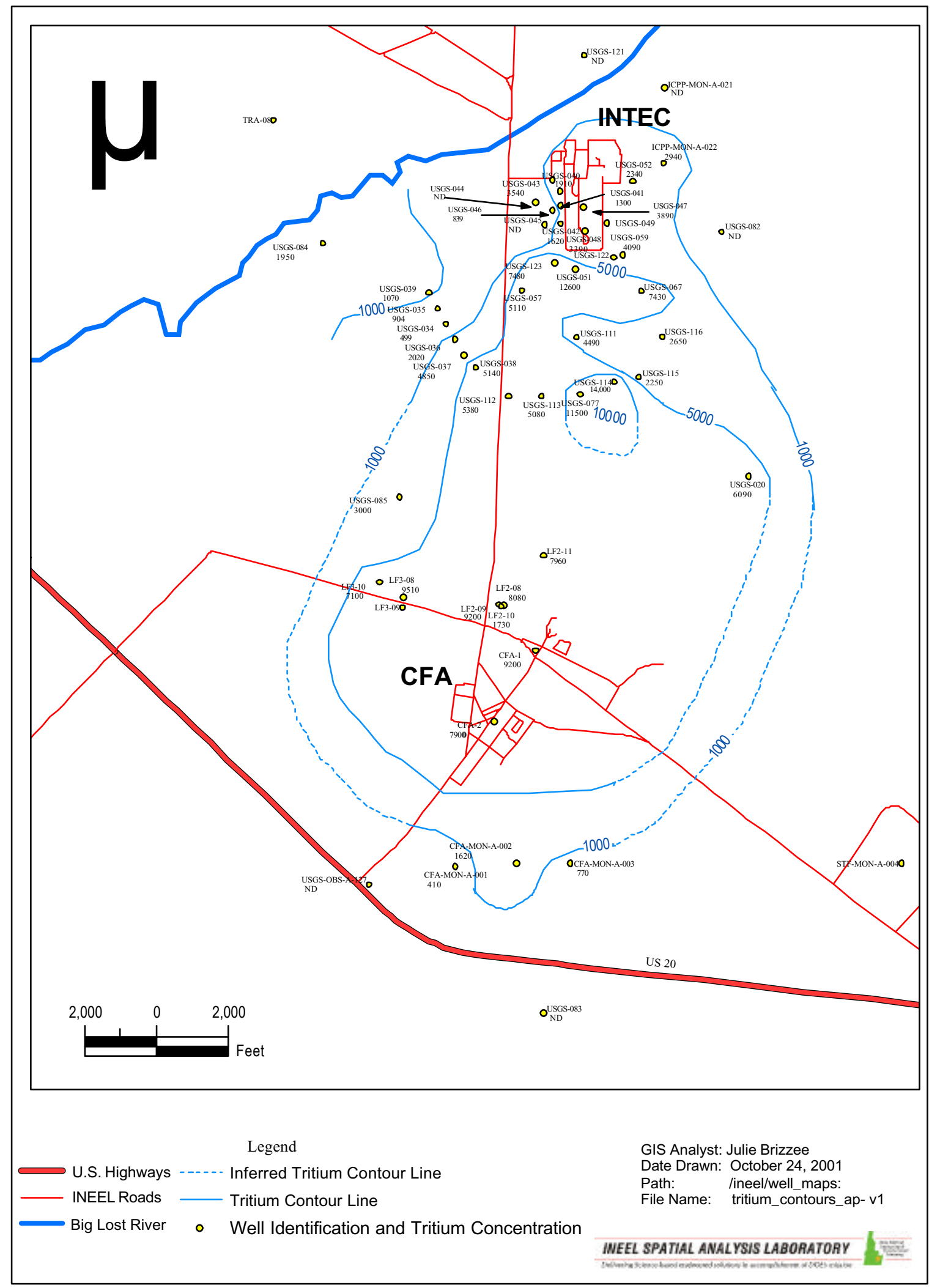

Figure 4. Distribution of tritium in the SRPA in 2001. 
USGS-123

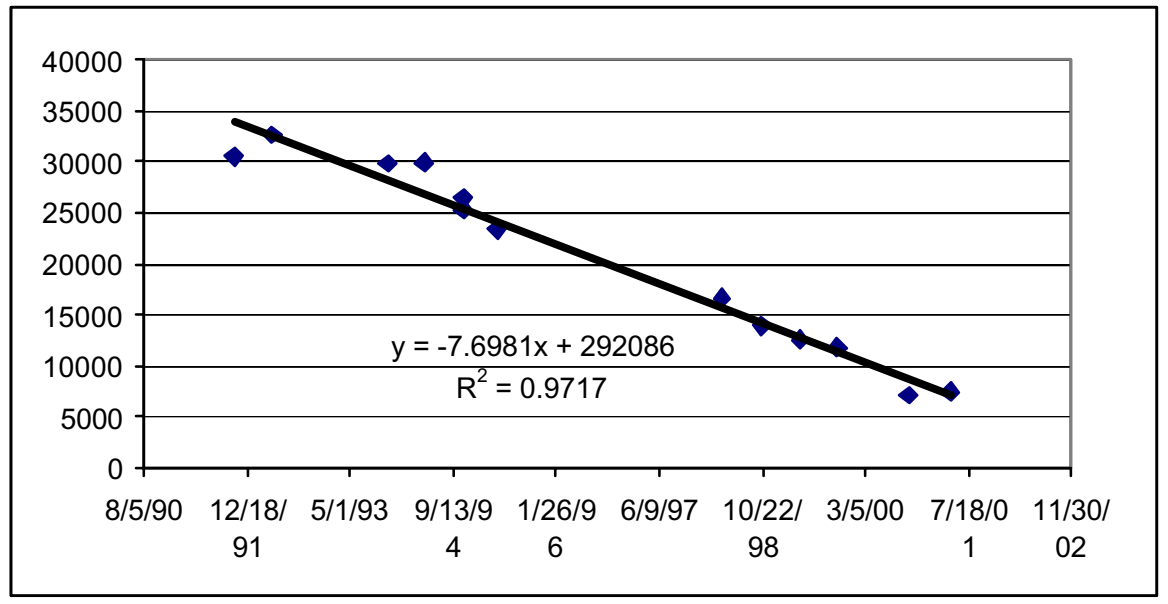

USGS-112

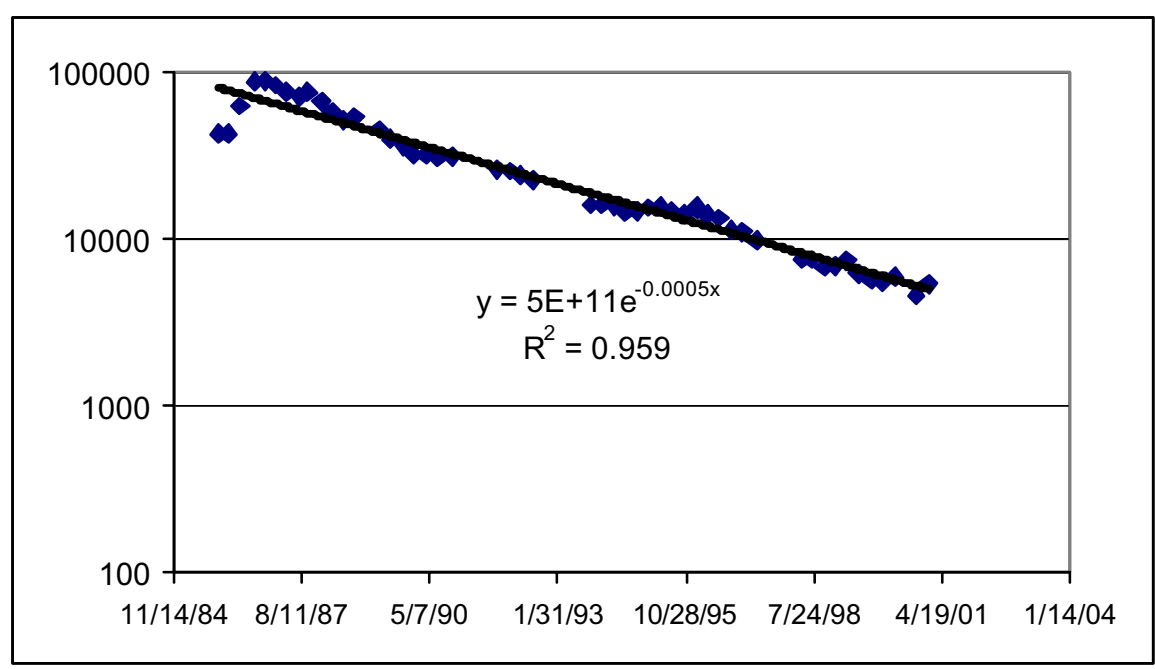

USGS-113

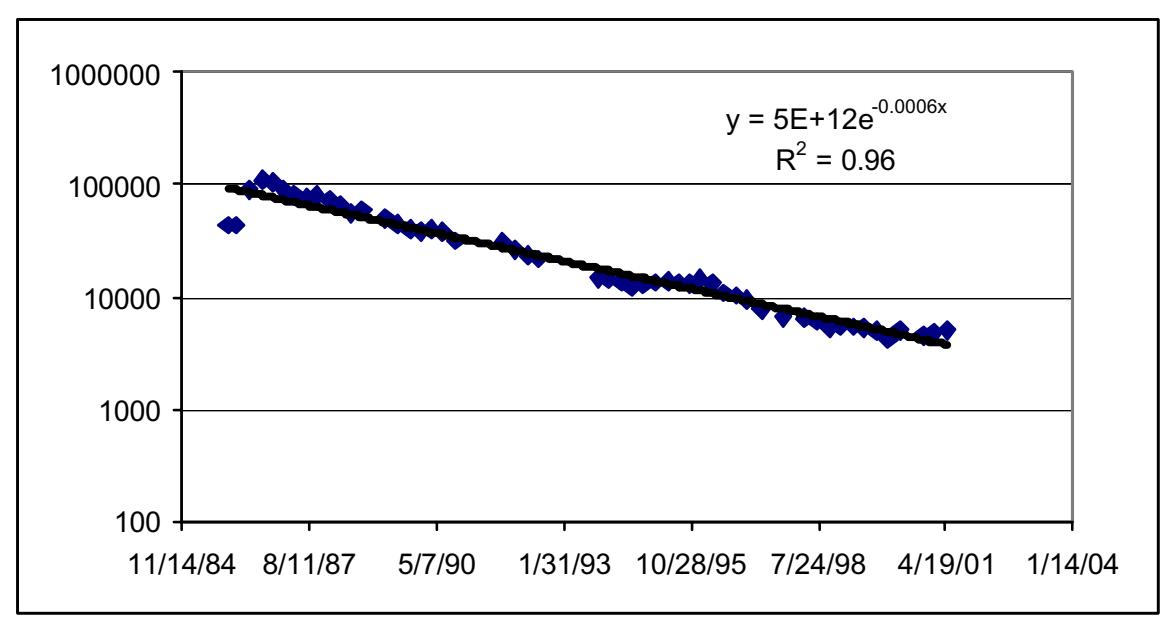

Figure 5. Tritium concentration trends for select wells near INTEC. 
USGS-47

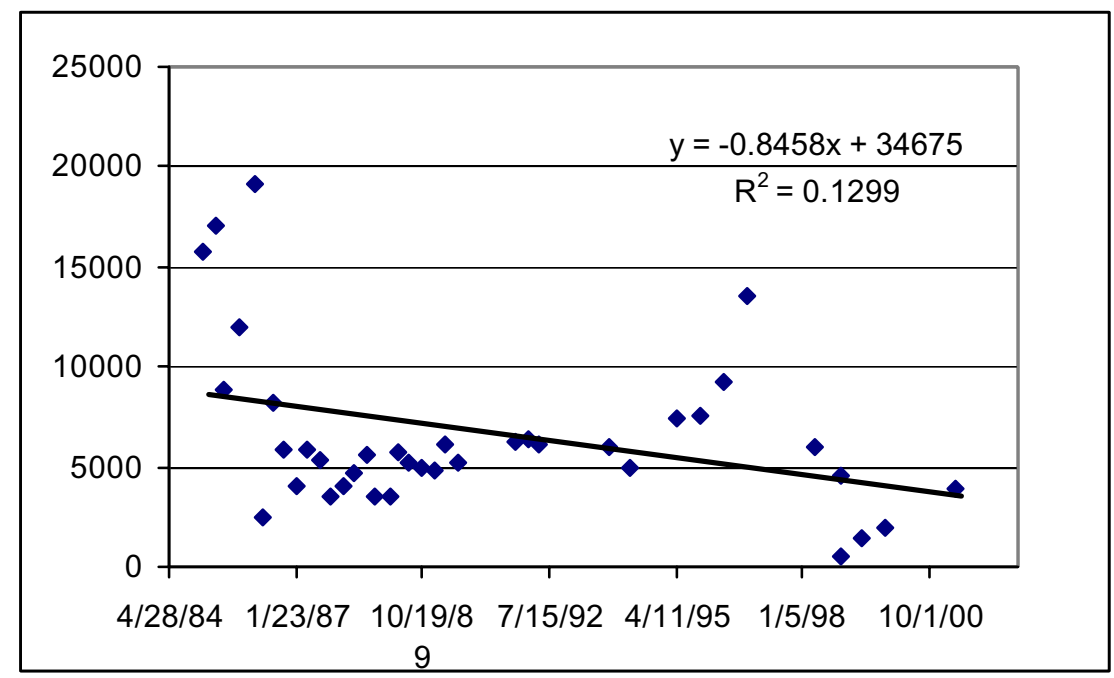

USGS-57

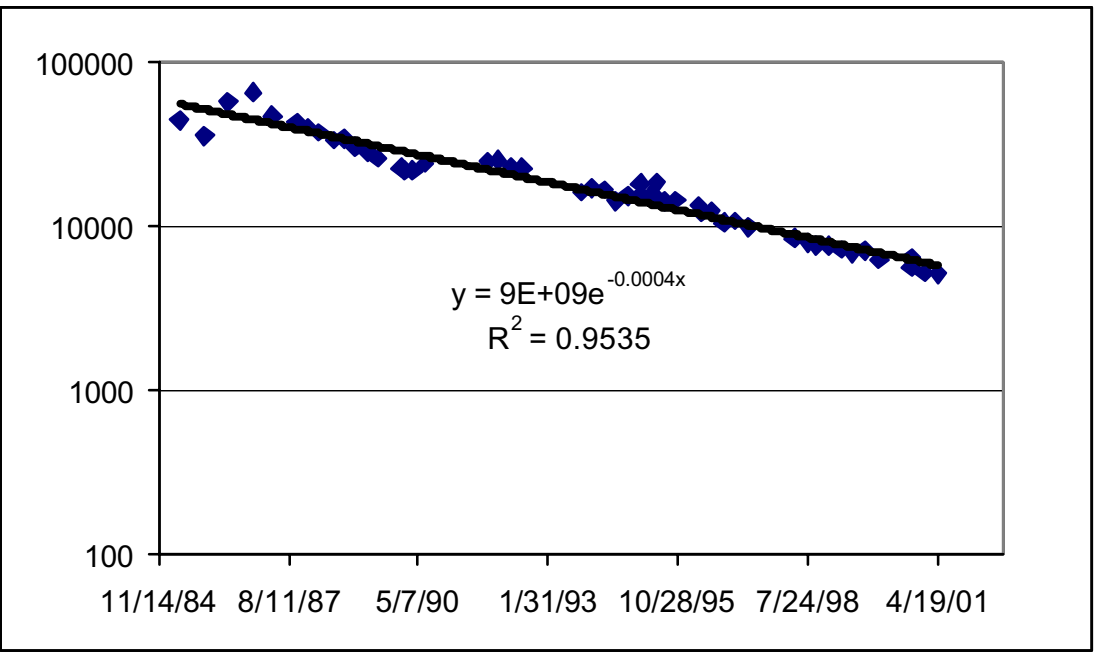

\section{USGS-67}

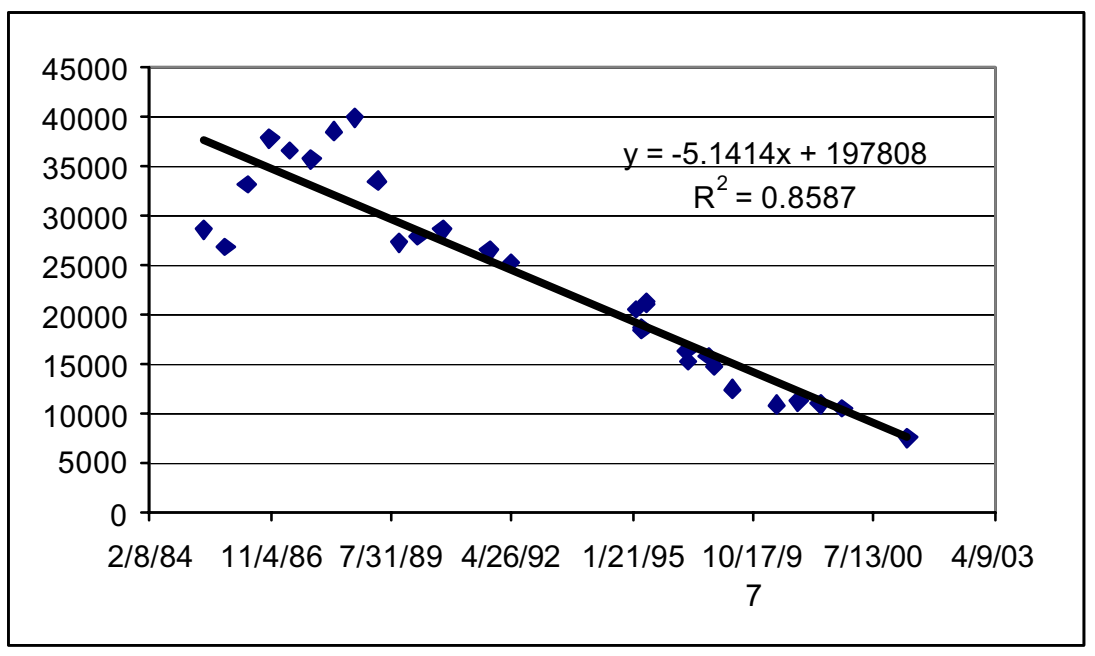

Figure 5. (continued). 


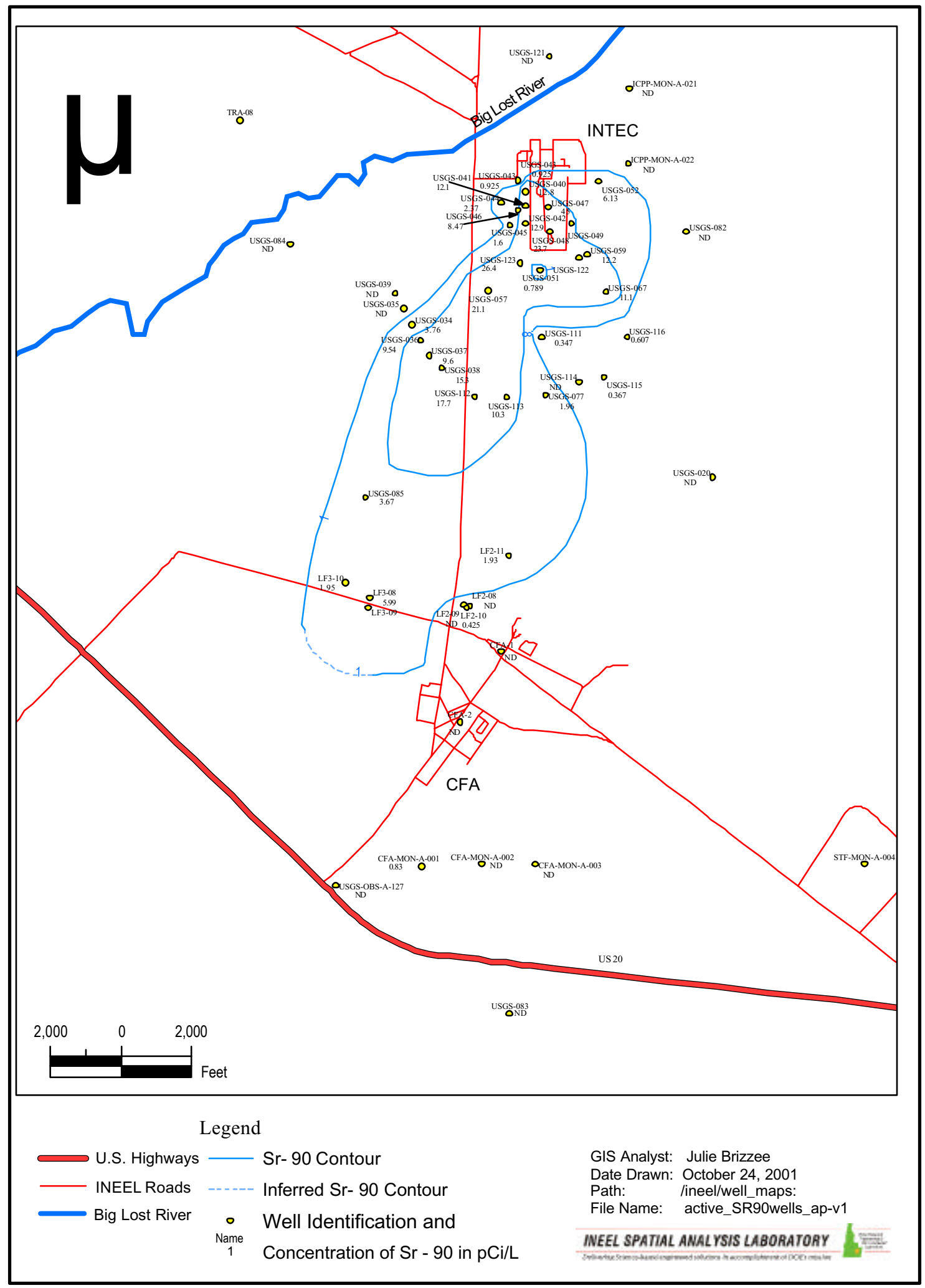

Figure 6. Distribution of Sr-90 in the SRPA in 2001. 
USGS-123

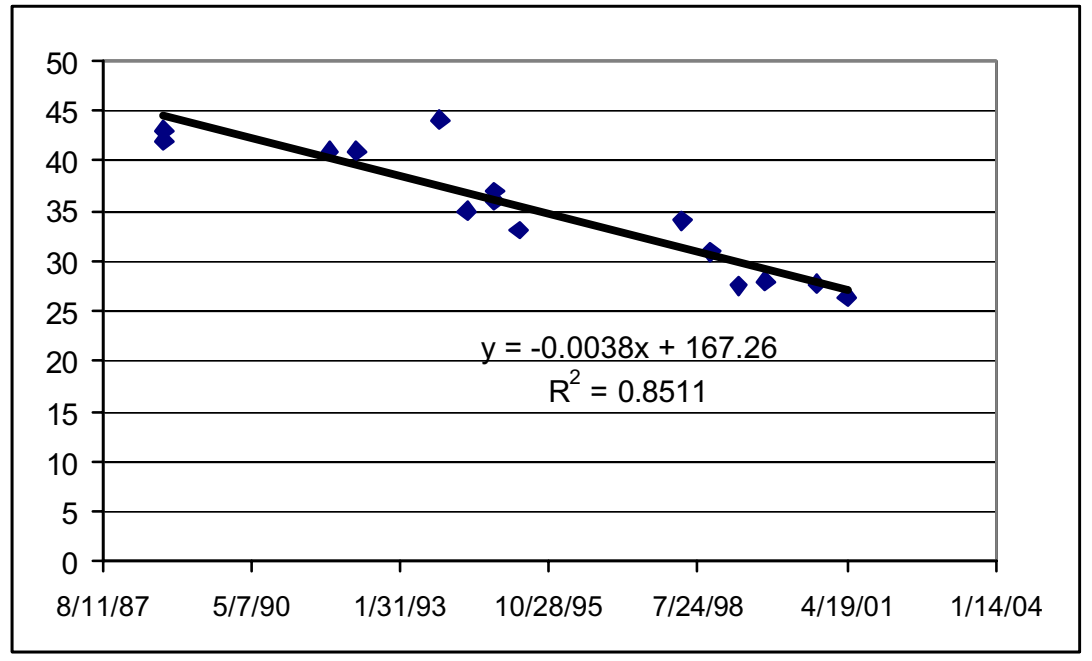

USGS-57

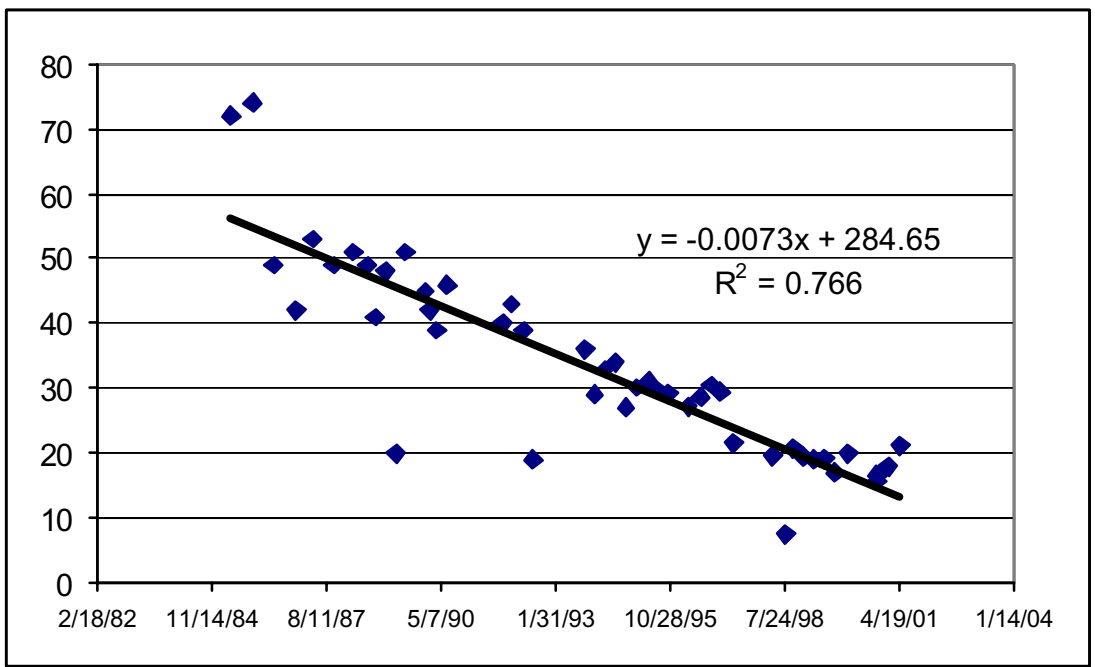

USGS-112

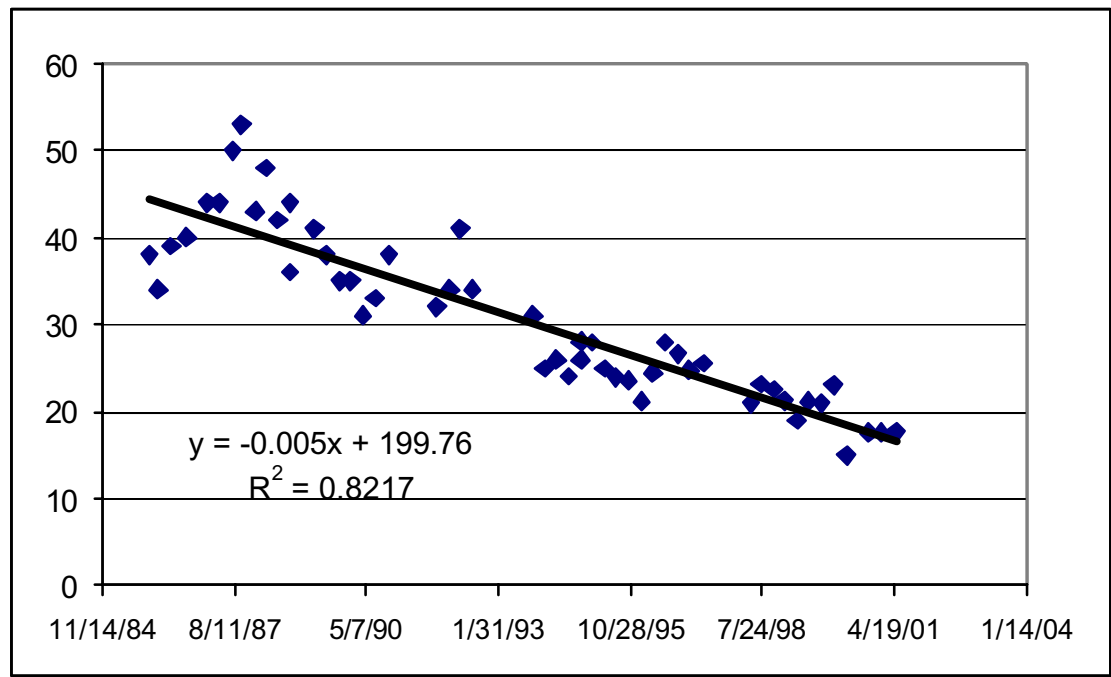

Figure 7. Strontium-90 concentration trends for select wells near INTEC. 
USGS-113

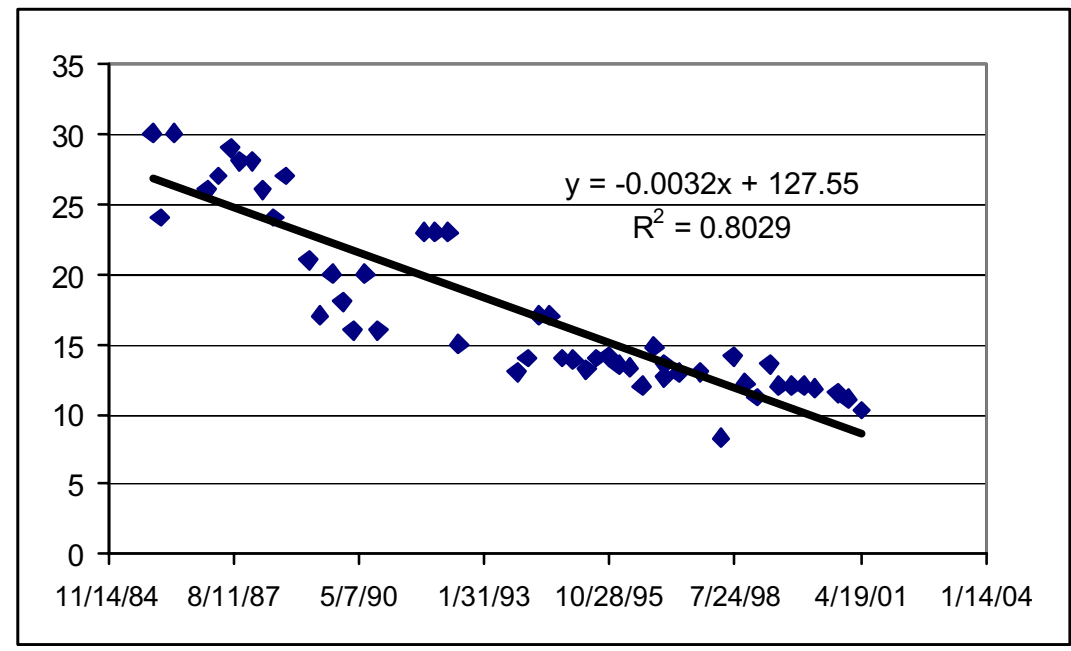

USGS-47

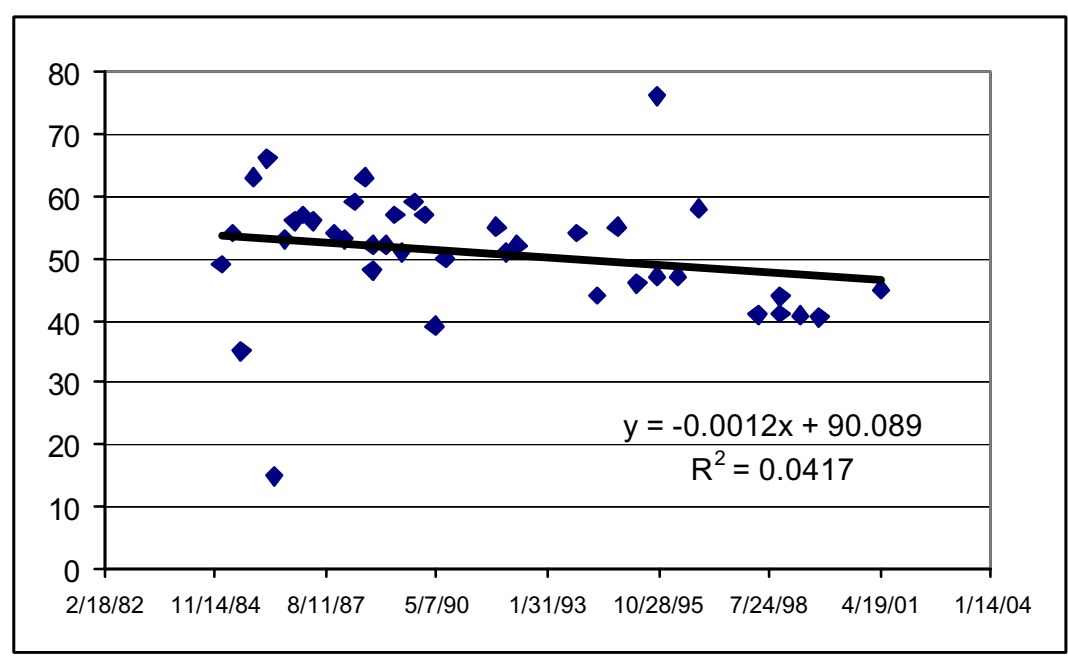

USGS-67

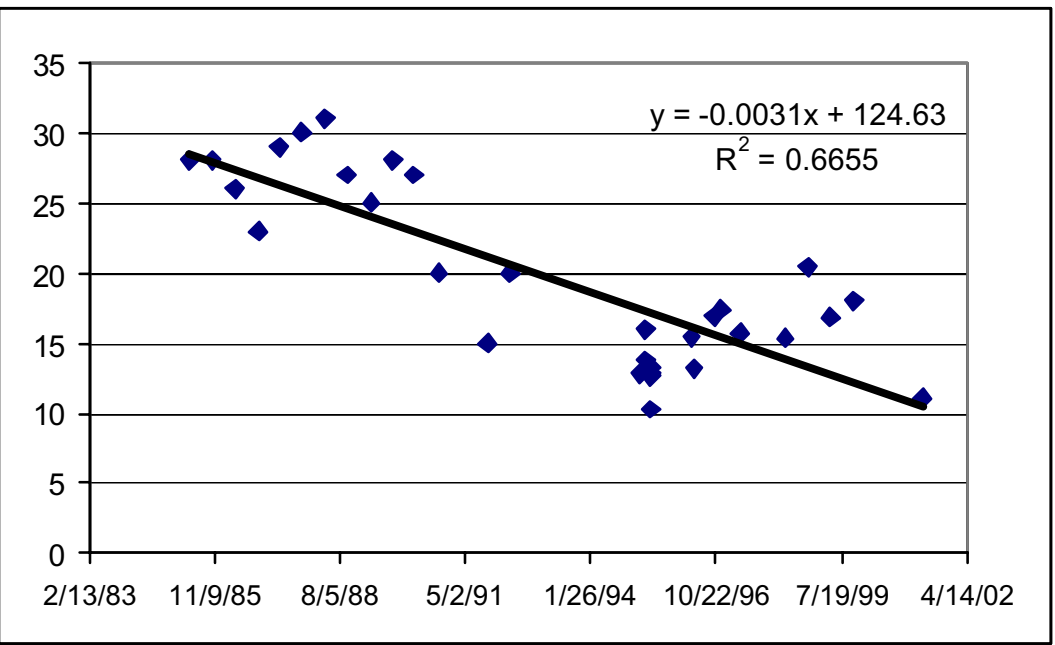

Figure 7. (continued). 


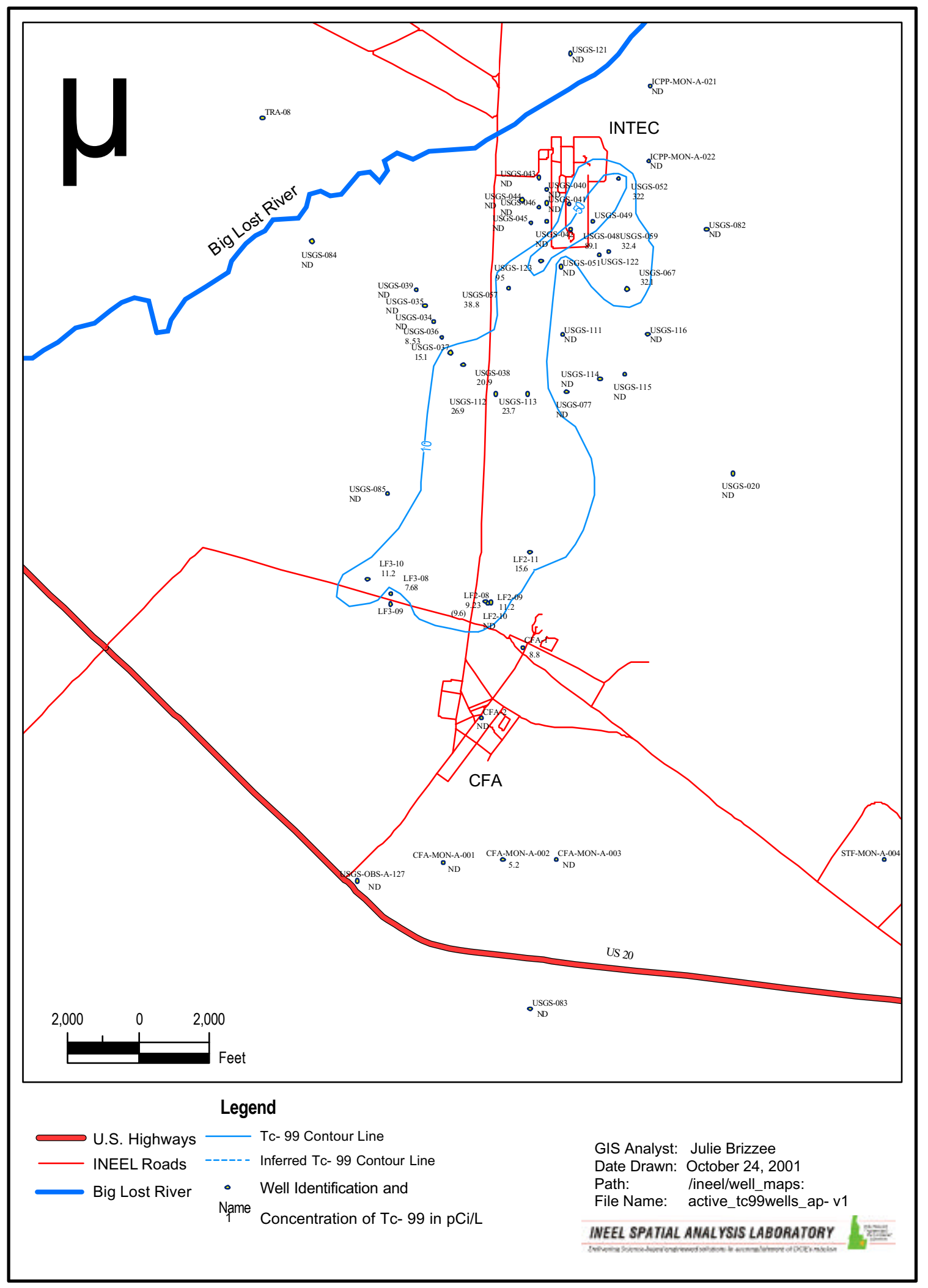

Figure 8. Distribution of Tc-99 in the SRPA in 2001. 


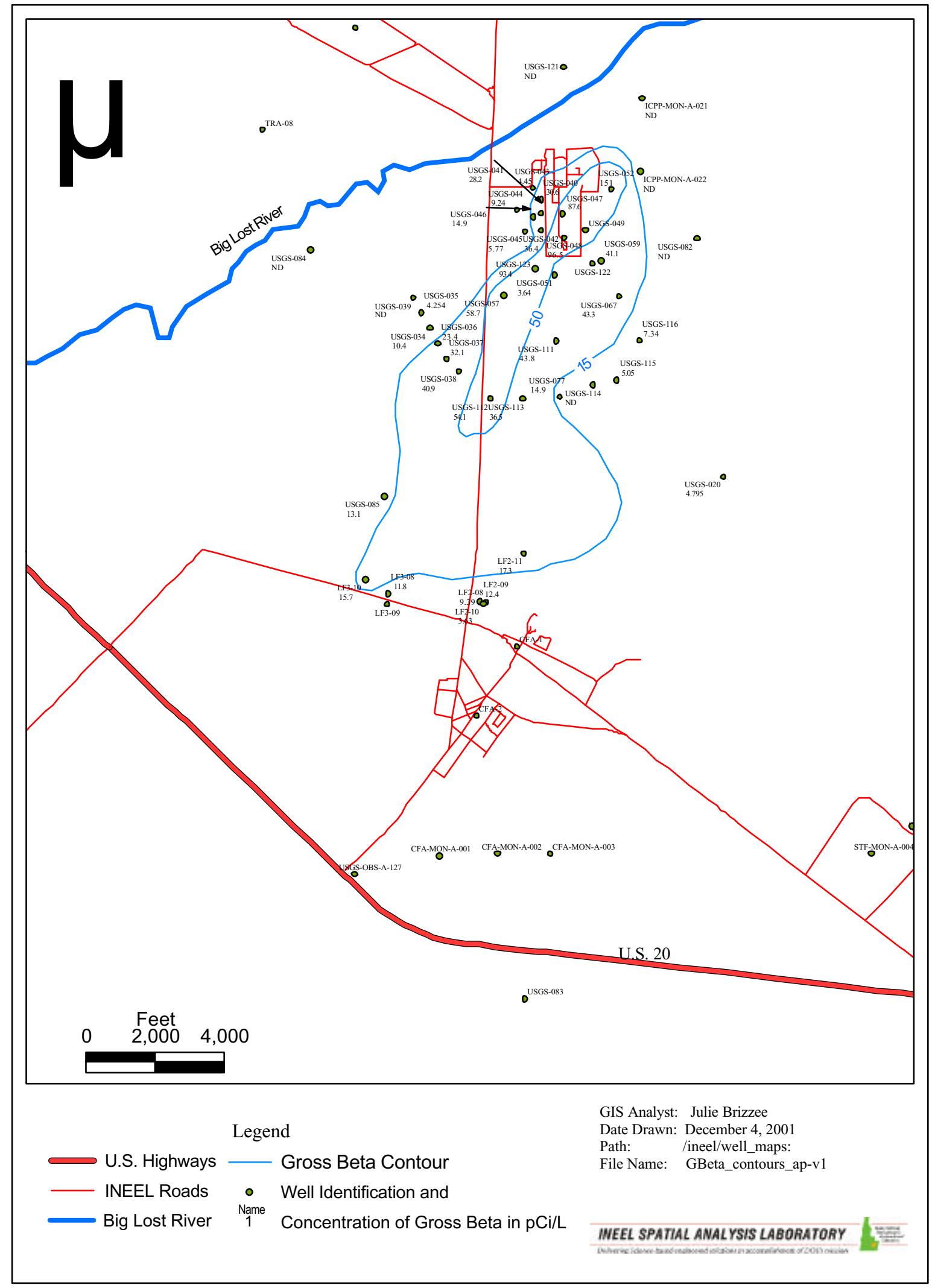

Figure 9. Distribution of gross beta in the SRPA in 2001. 


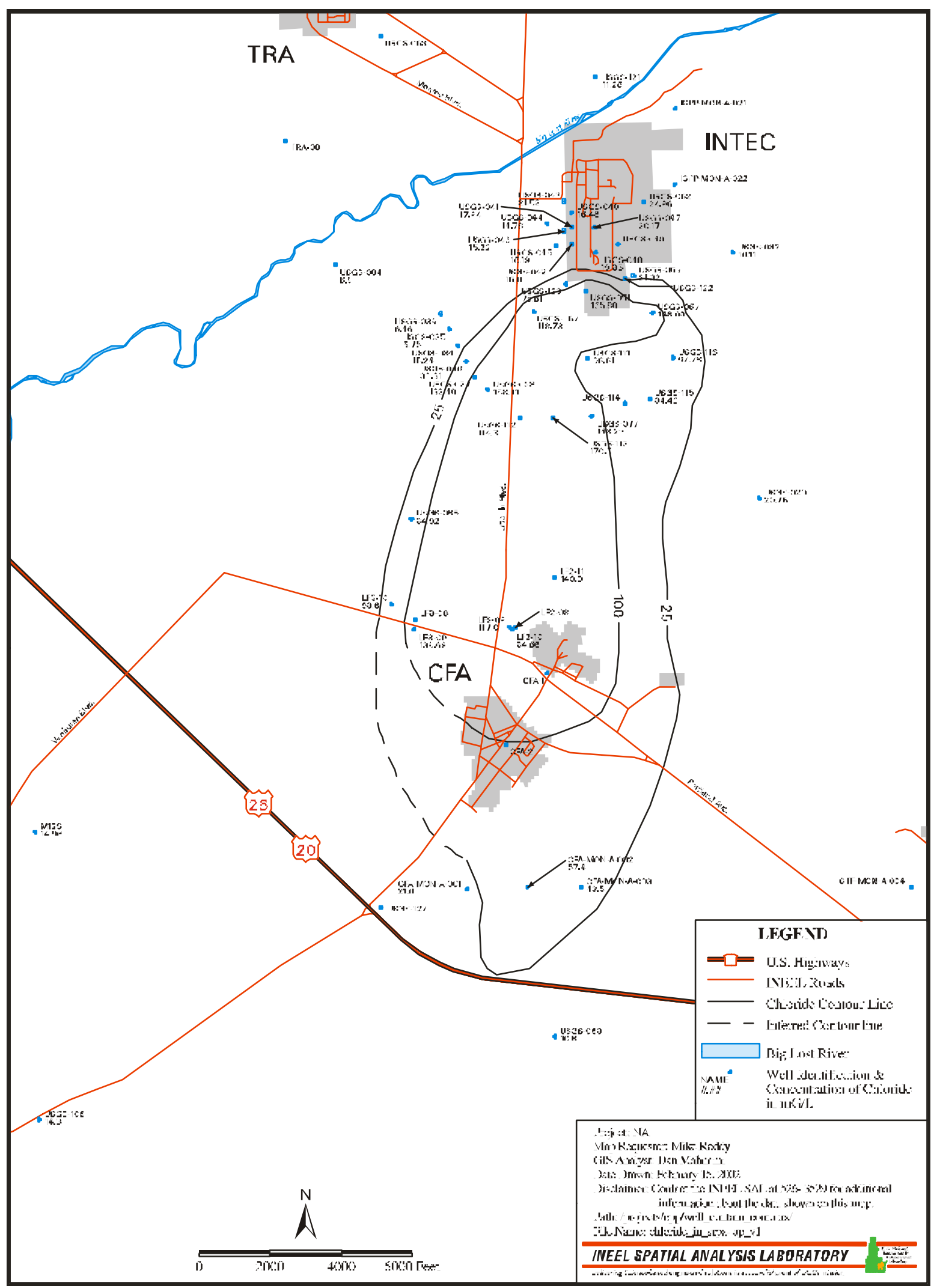

Figure 10. Distribution of chloride in the SRPA (USGS and WAG 4 data). 


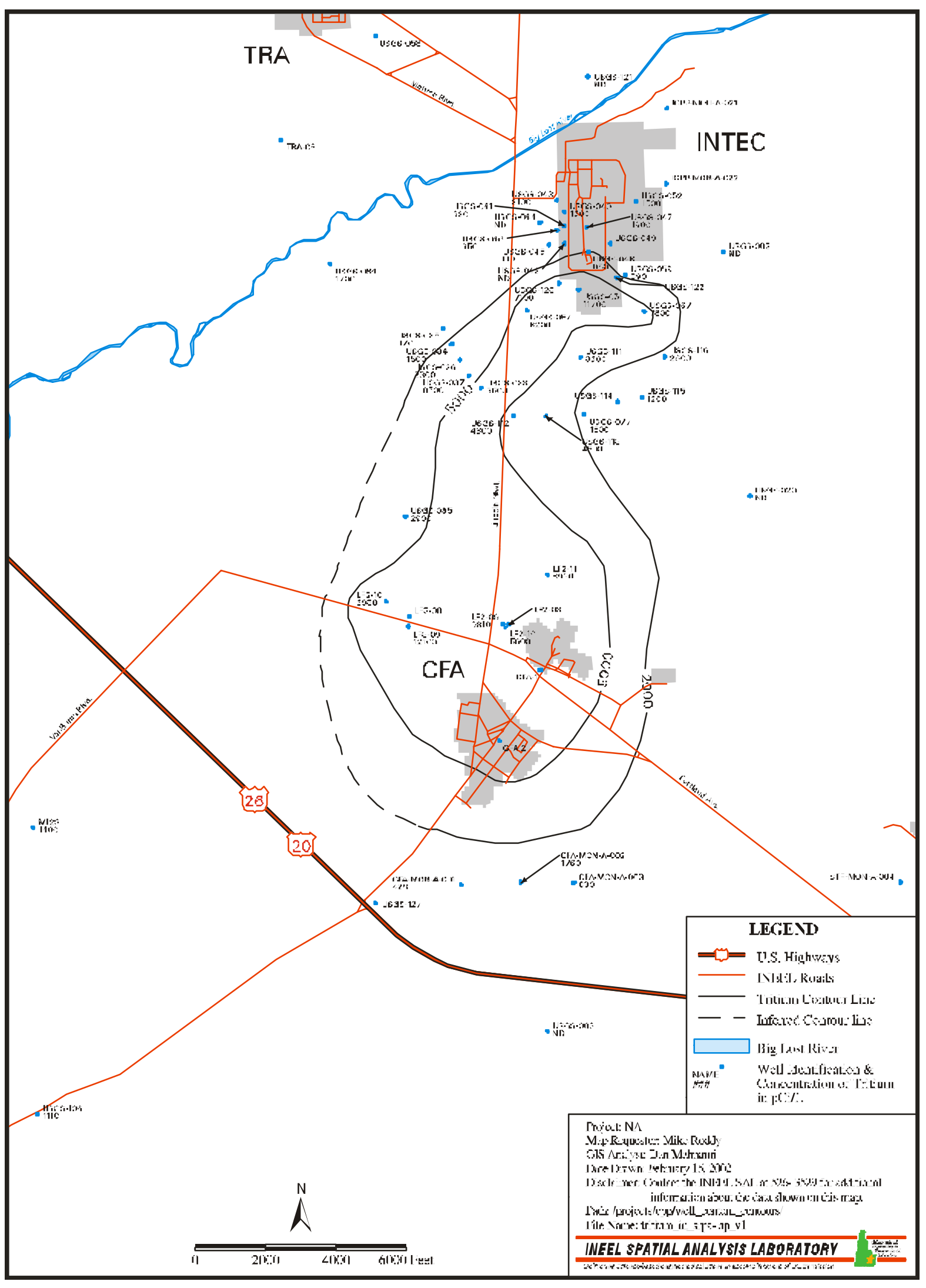

Figure 11. Distribution of tritium in the SRPA (USGS and WAG 4 data). 
LF 2-08

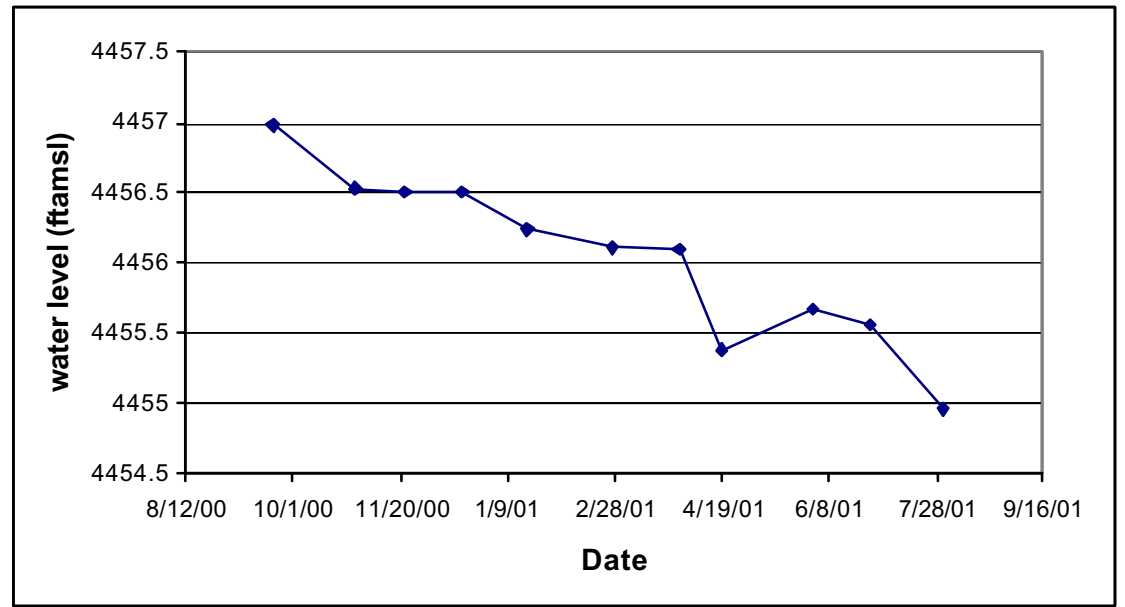

USGS-112

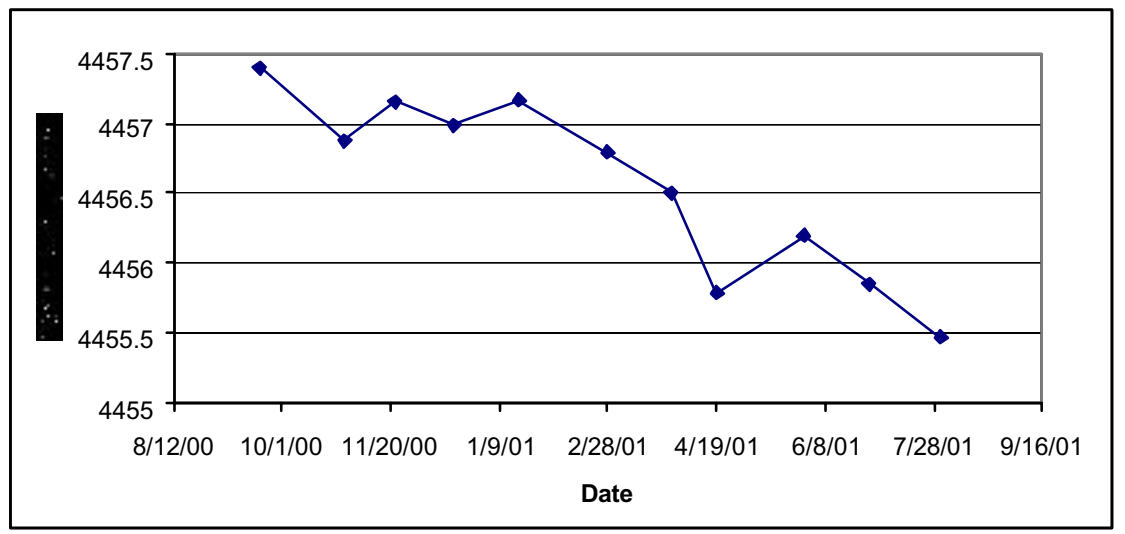

USGS-082

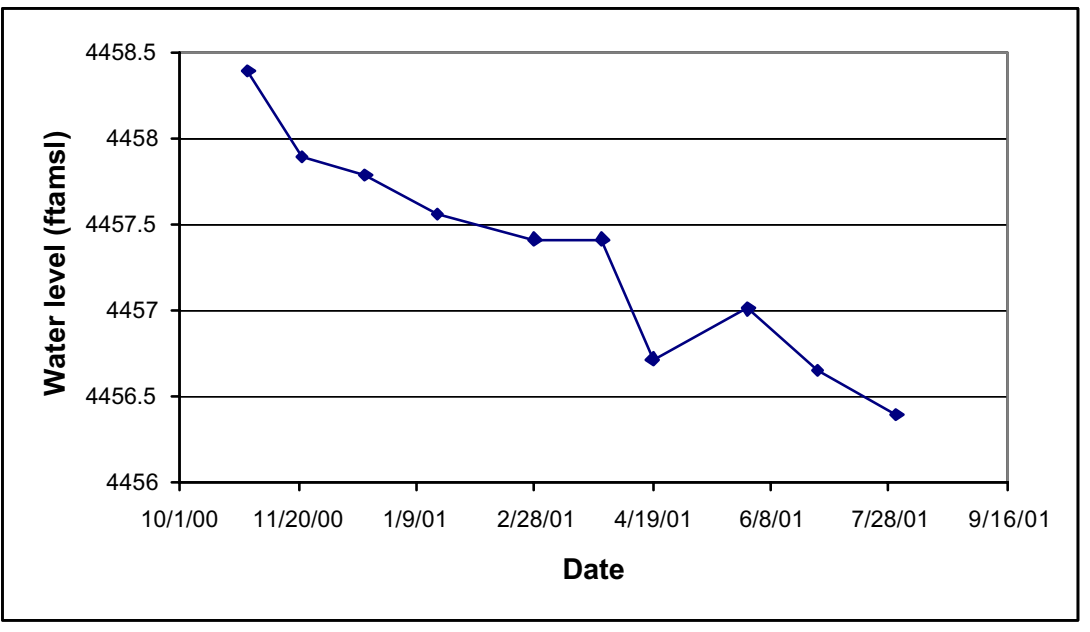

Figure 12. Hydrographs for select wells in the INTEC, CFA, RWMC, and STF areas. 
STF-MON-A-003

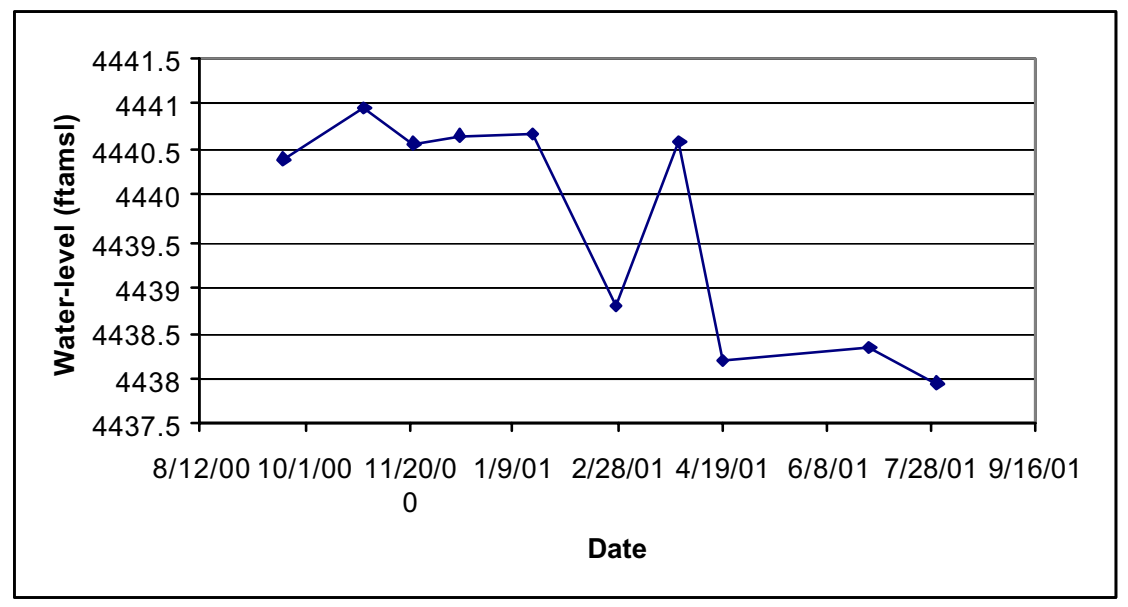

SOUTH-MON-A-002 (M12S)

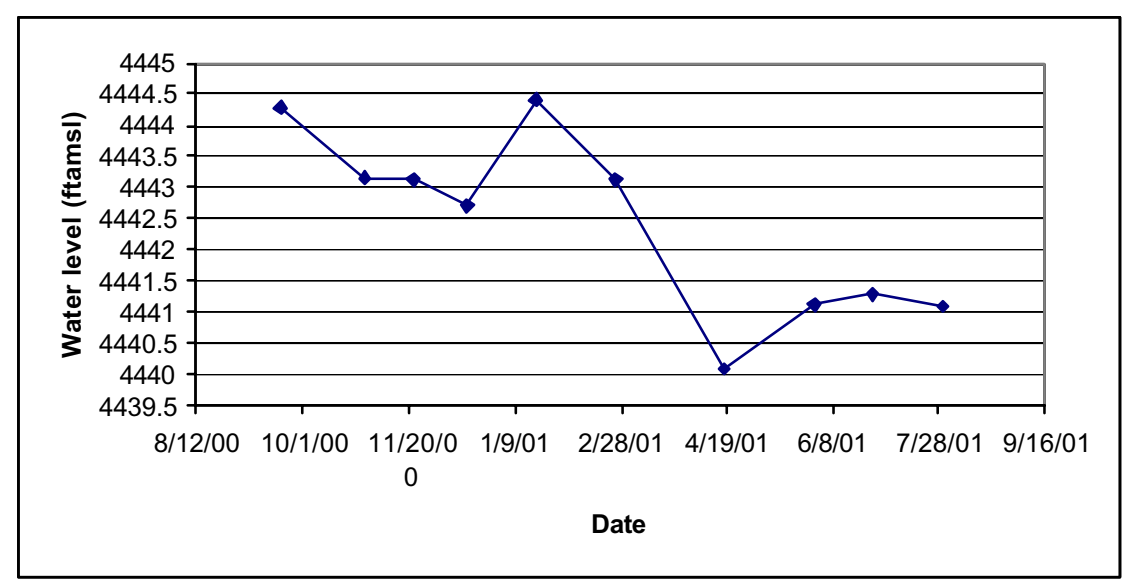

\section{CFA-MON-A-001}

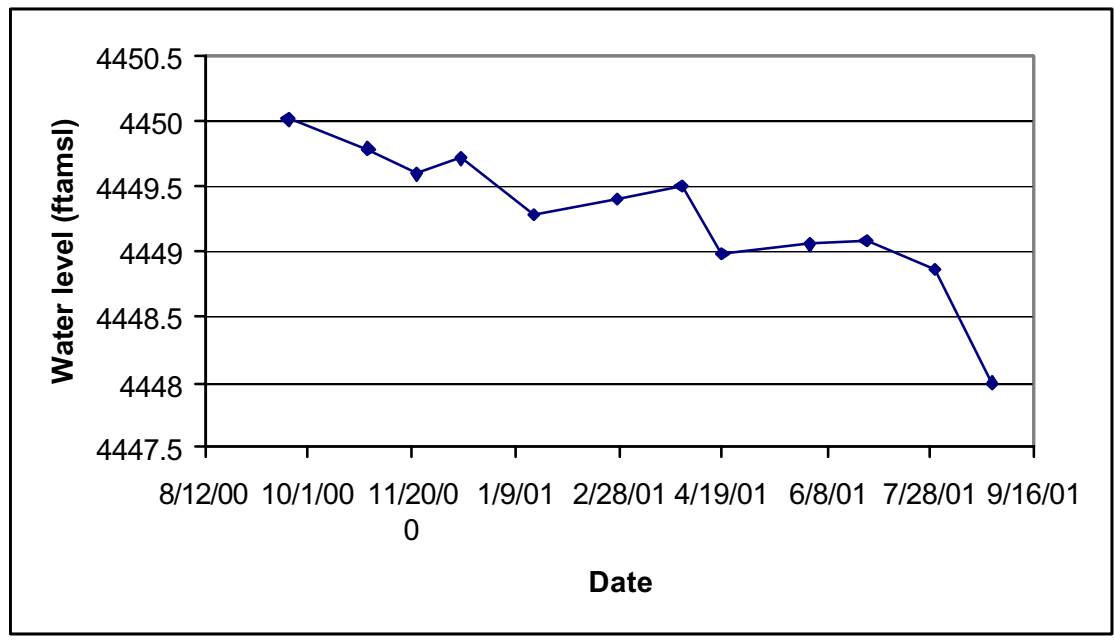

Figure 12. (continued). 


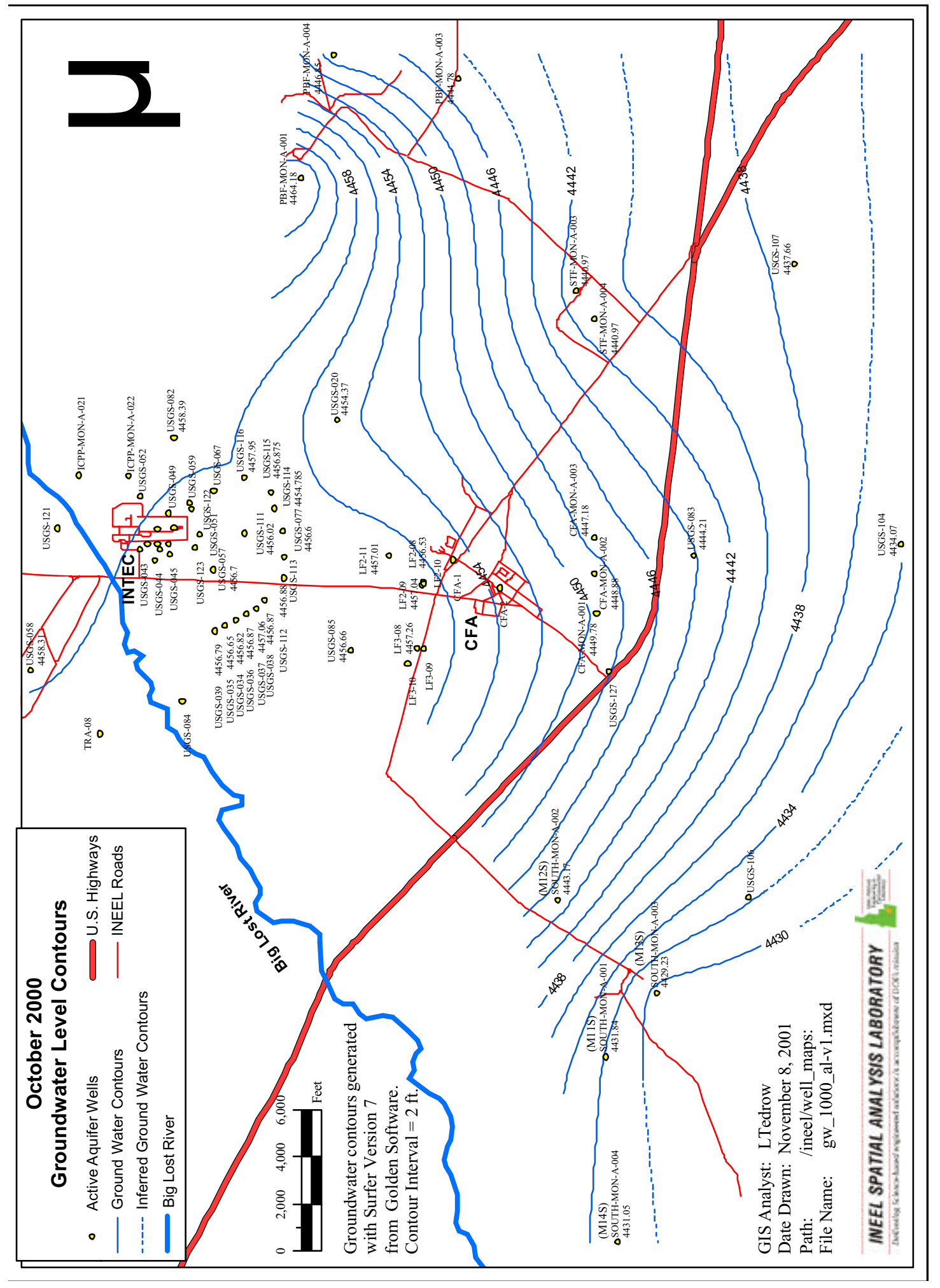

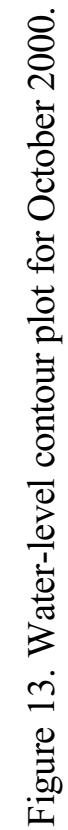




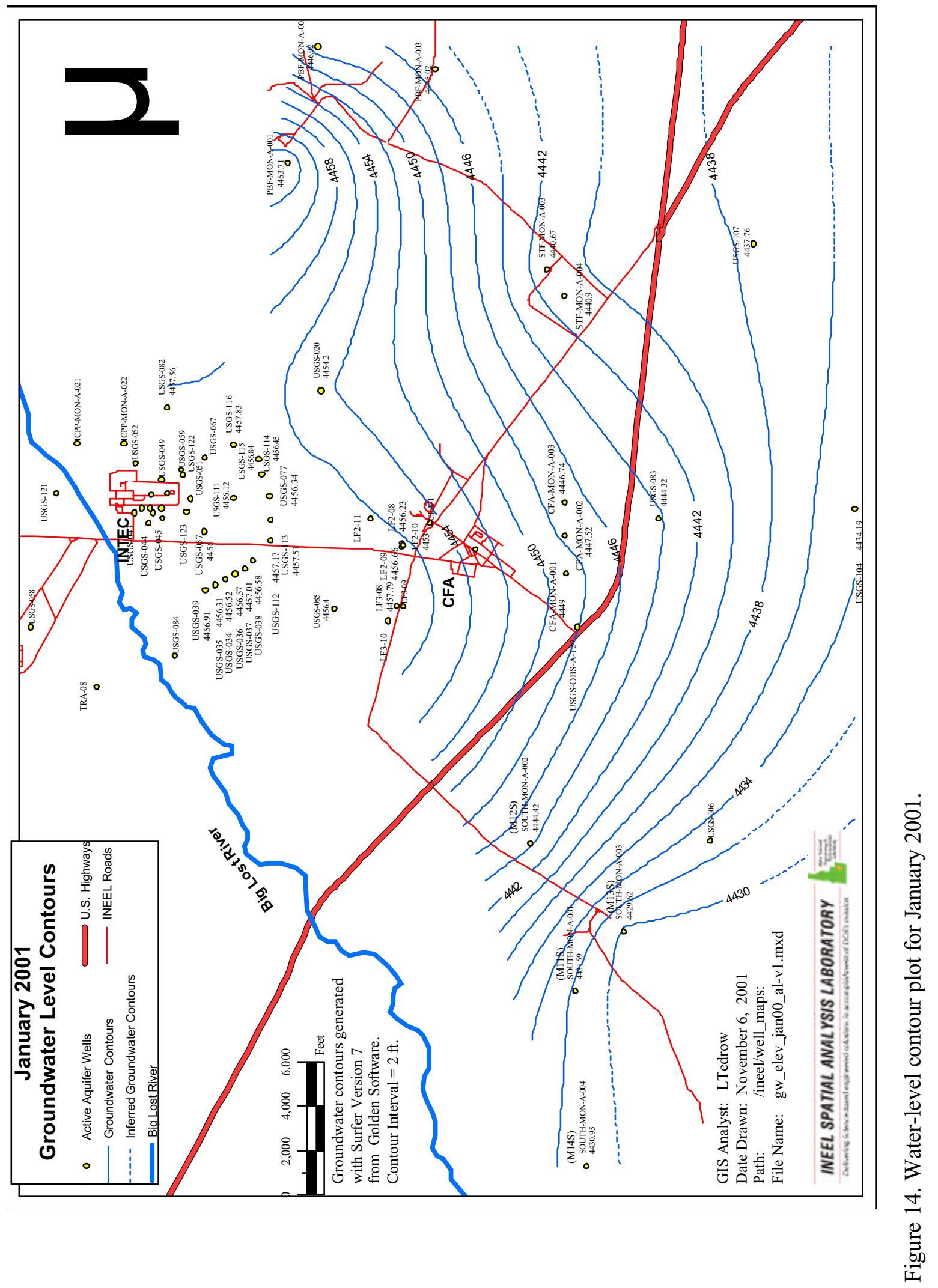




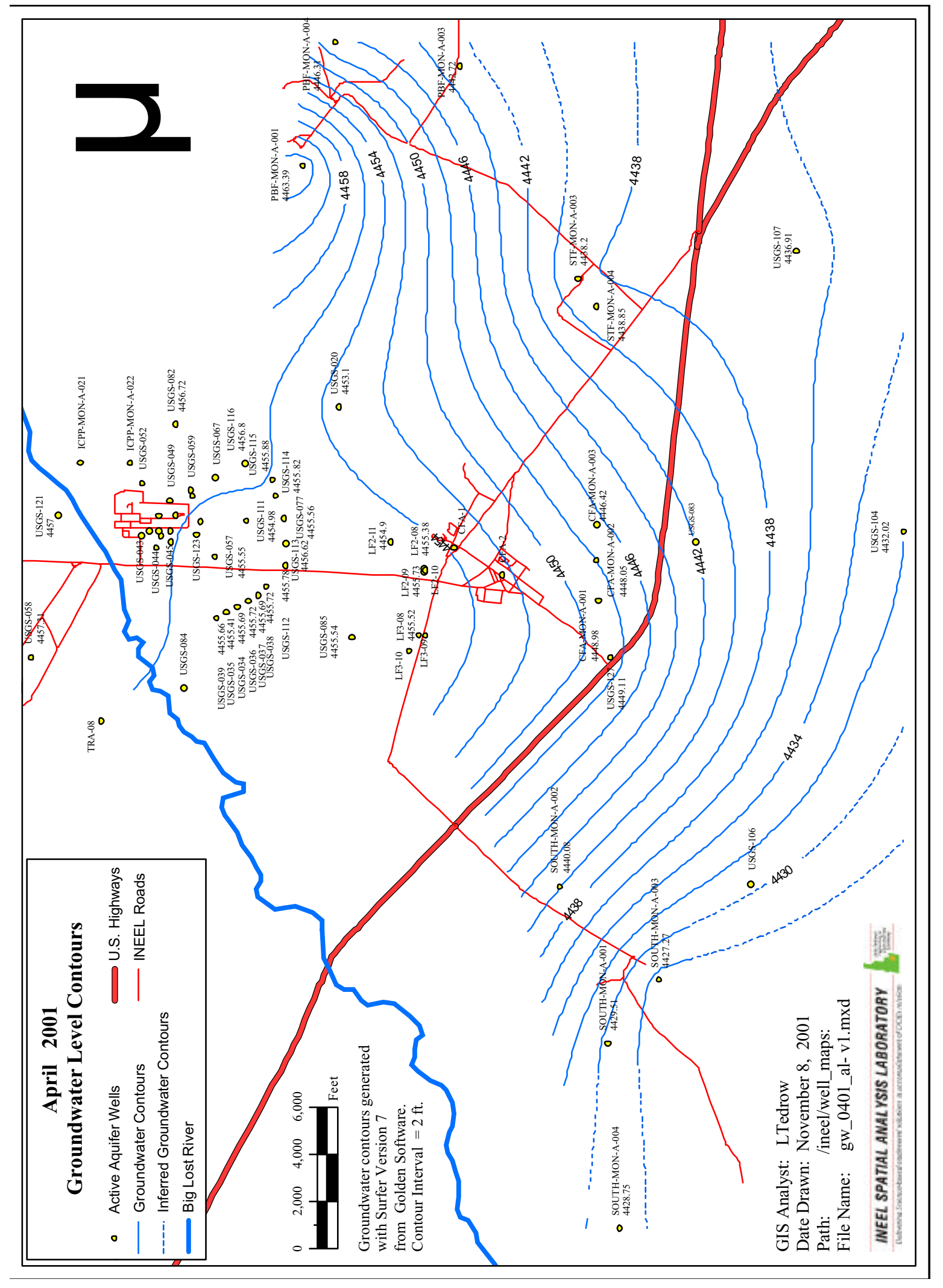

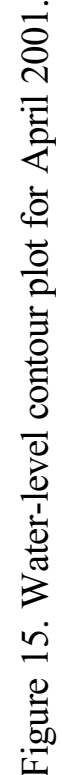




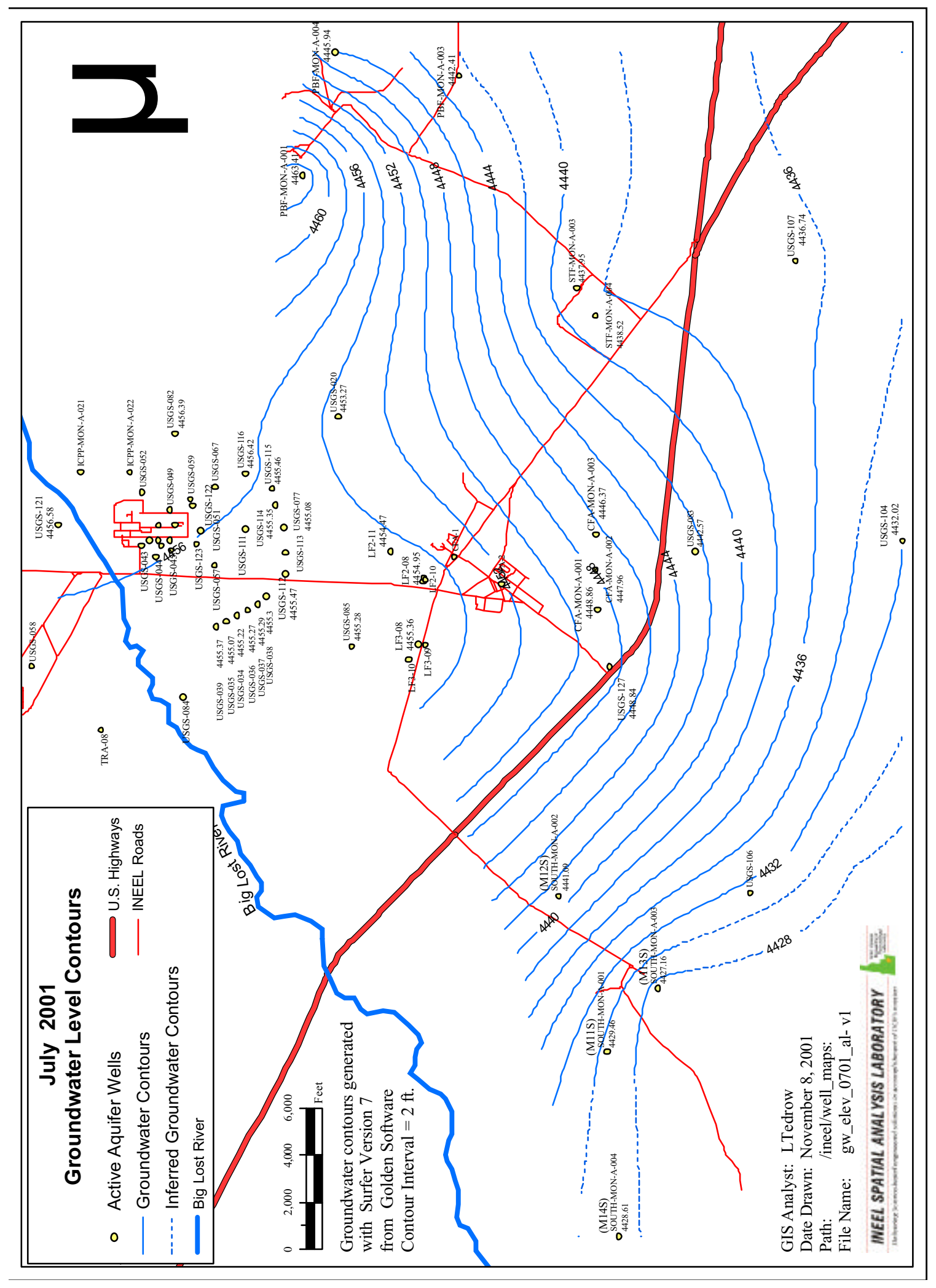

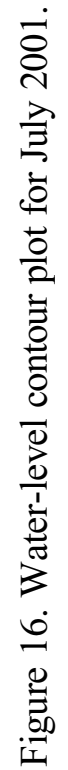




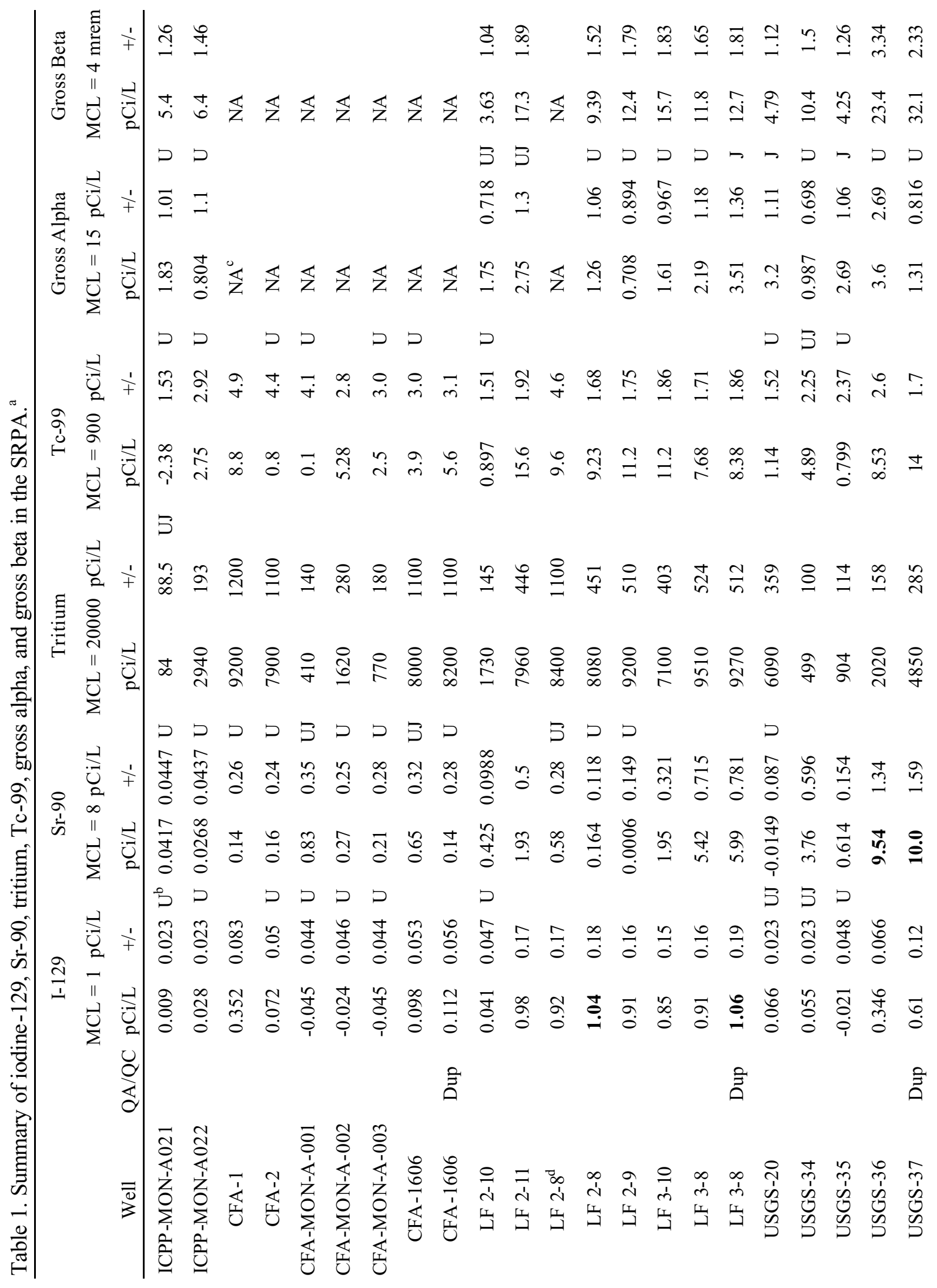




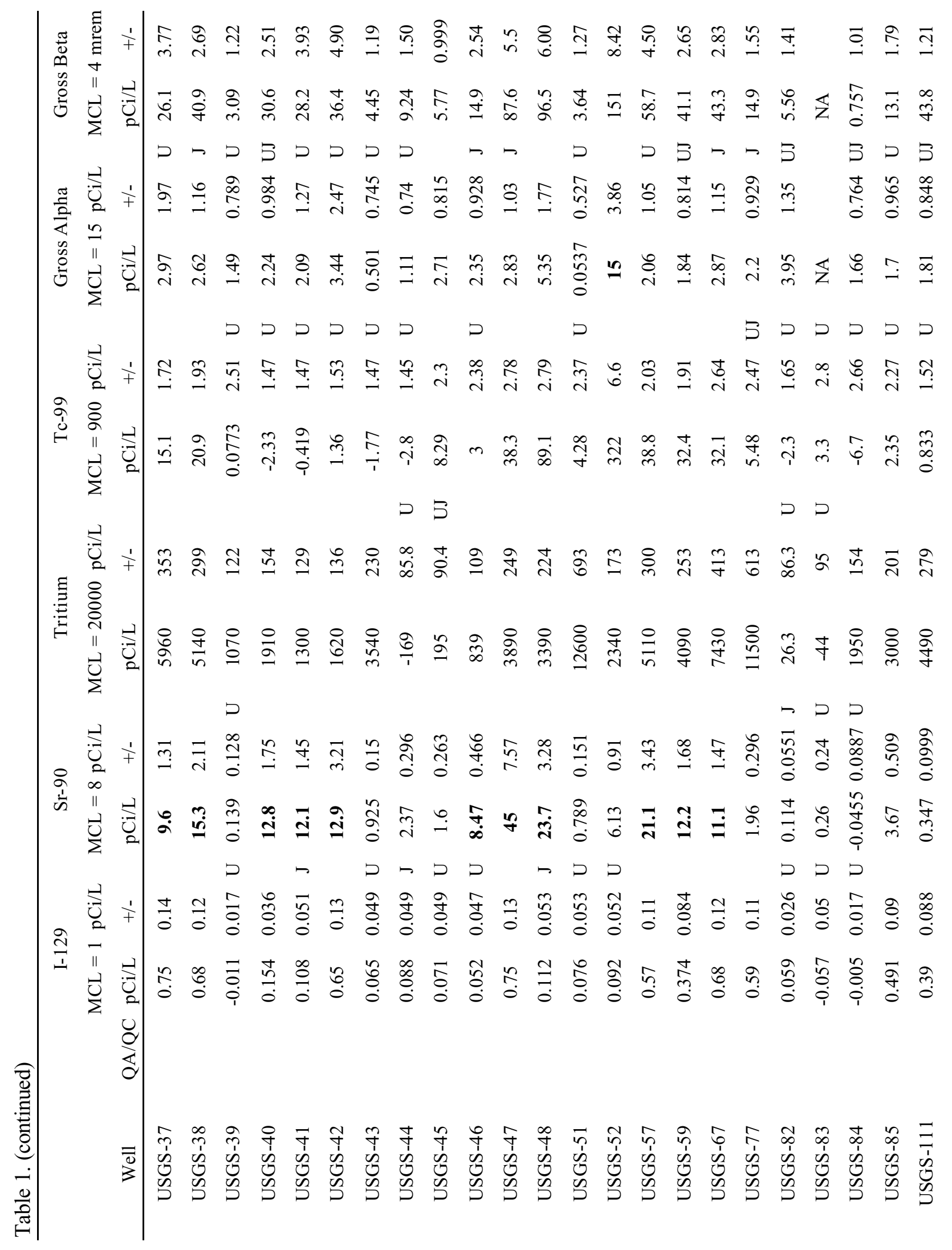




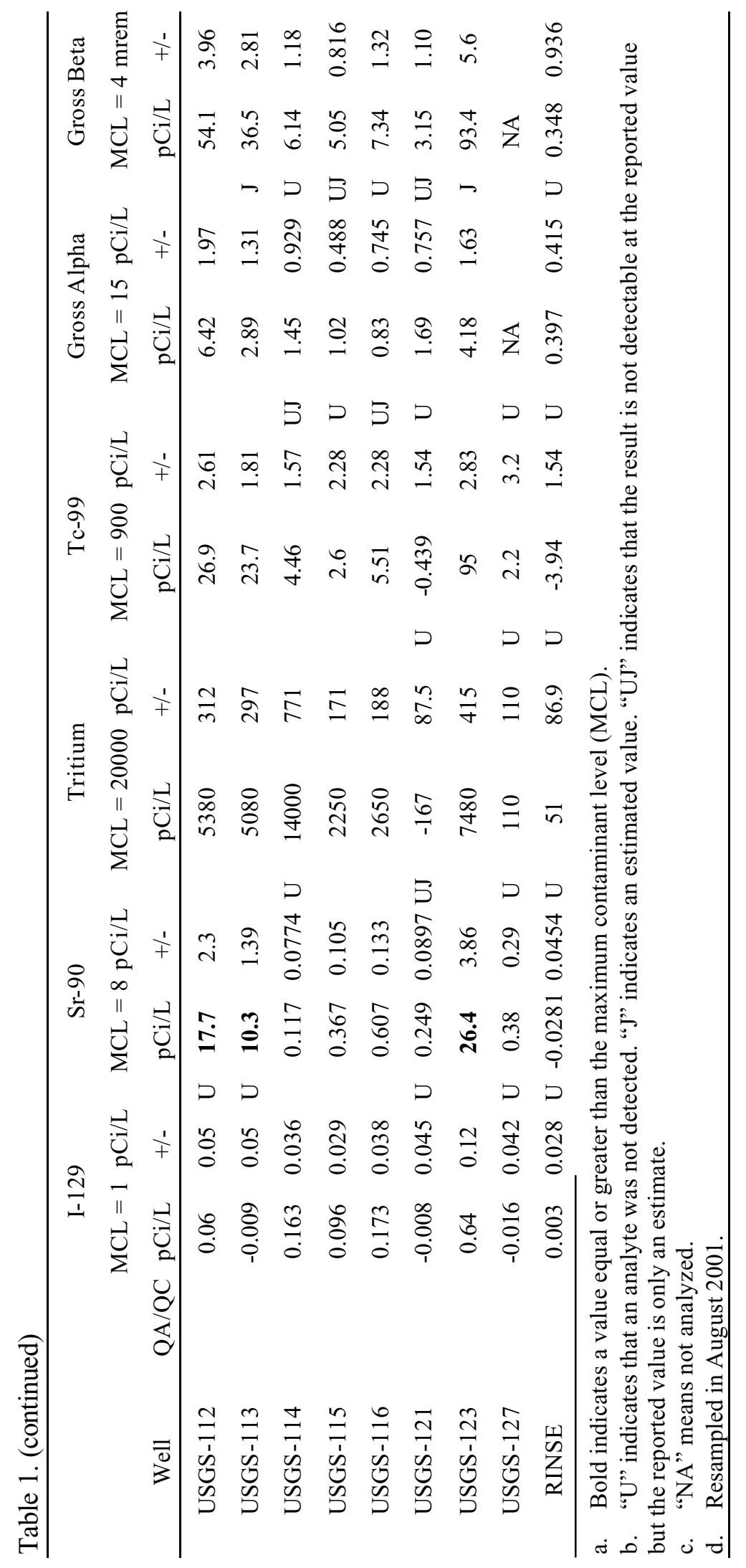




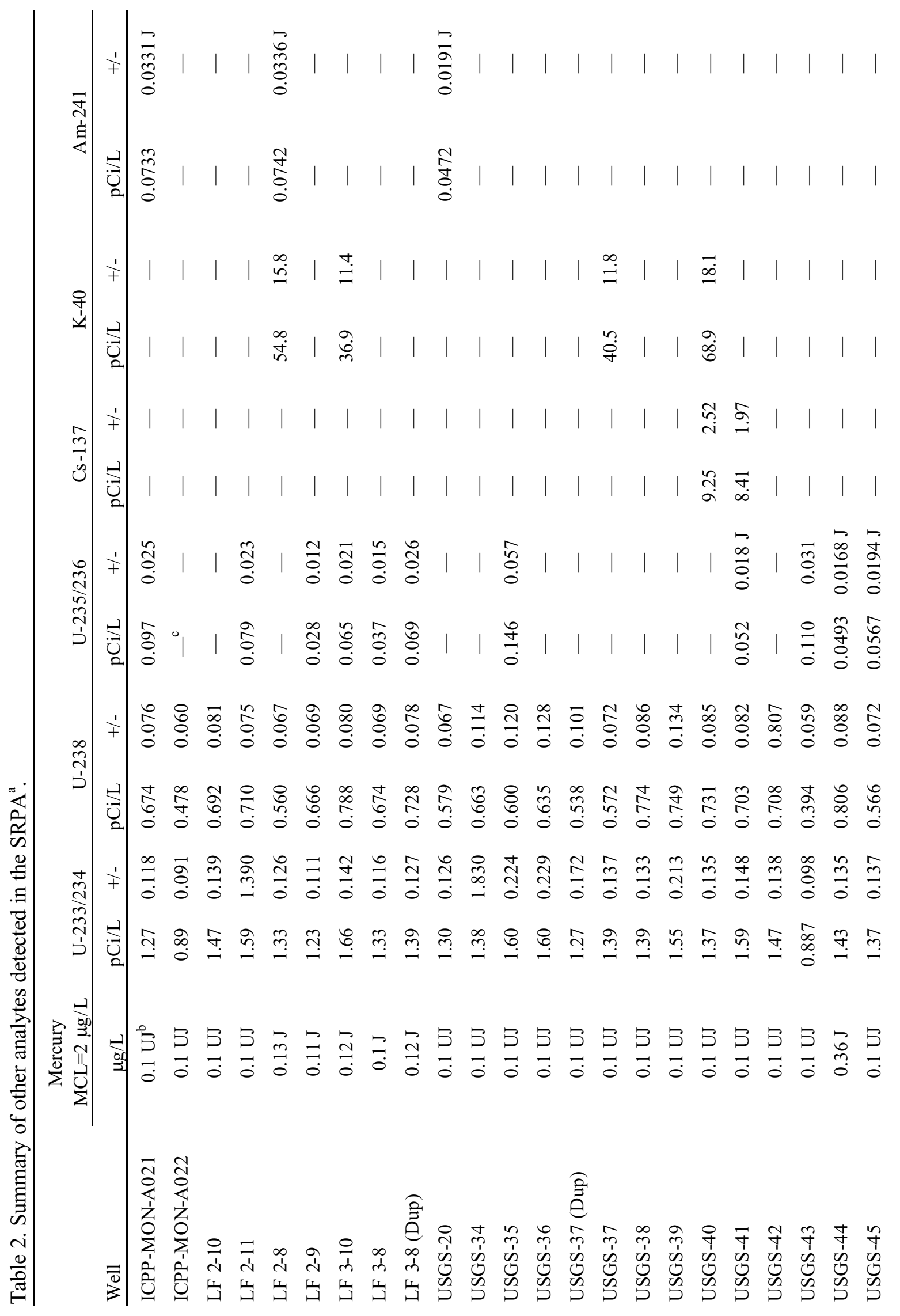




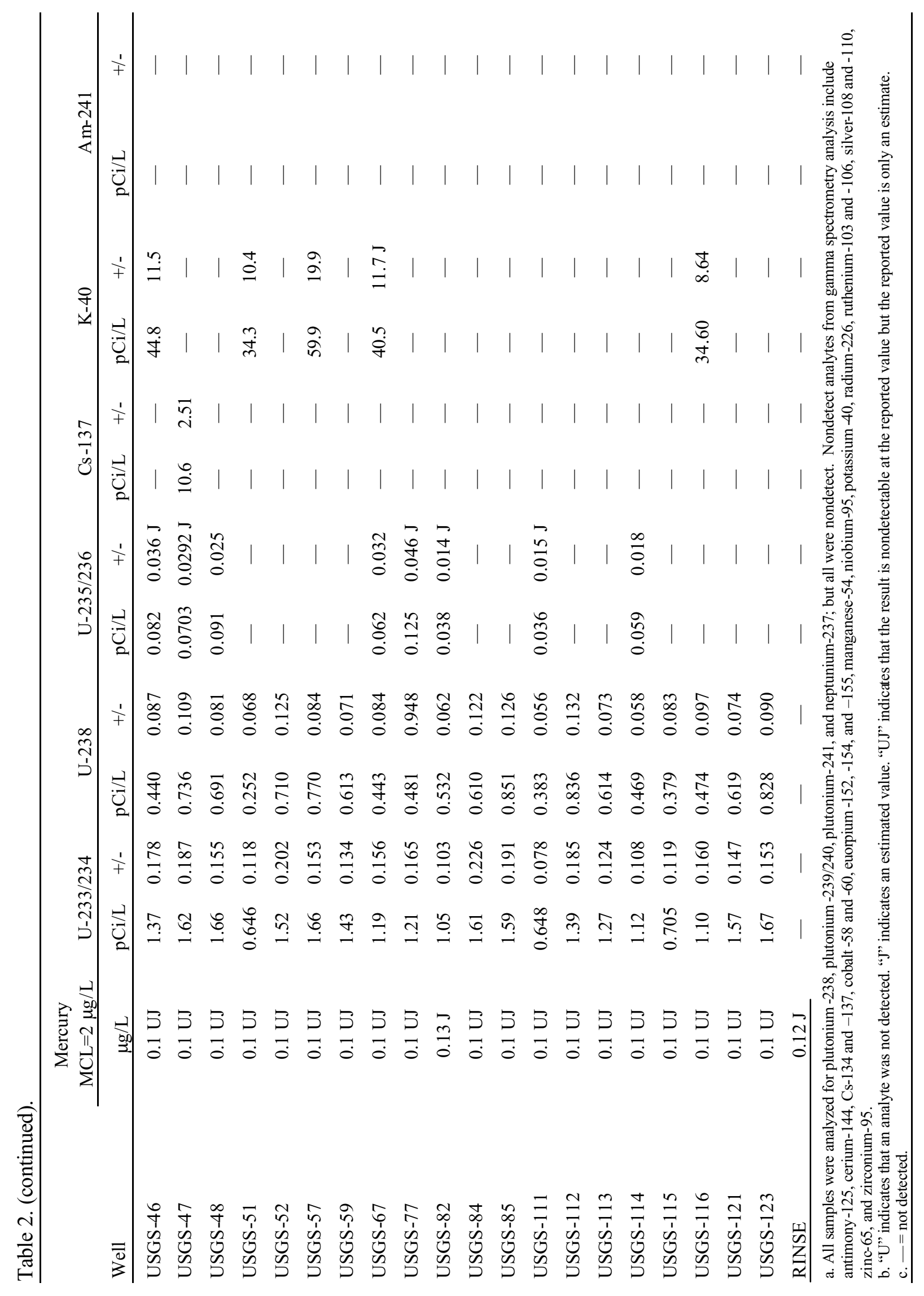


Table 3. Summary of tritium and chloride data from USGS and WAG 4 sampling in 2000.

\begin{tabular}{|c|c|c|c|c|}
\hline Well & $\begin{array}{c}\text { Date } \\
\text { Sampled }\end{array}$ & $\begin{array}{l}\text { Tritium } \\
(\mathrm{pCi} / \mathrm{L})\end{array}$ & $\begin{array}{c}+/- \\
\text { uncertainty }\end{array}$ & $\begin{array}{c}\text { Chloride } \\
(\mathrm{mg} / \mathrm{L})\end{array}$ \\
\hline CFA-MON-001 & Aug-00 & 426 & 86.4 & 21.6 \\
\hline CFA-MON-002 & Aug-00 & 1760 & 146 & 57.4 \\
\hline CFA-MON-003 & Aug-00 & 830 & 101 & 43.5 \\
\hline LF 2-10 & Oct-99 & 5600 & 600 & 34.66 \\
\hline LF 2-11 & Aug-00 & 8930 & 578 & 140 \\
\hline LF 2-9 & Aug-00 & 9810 & 633 & 117 \\
\hline LF 3-10 & Aug-00 & 6930 & 454 & 93.8 \\
\hline LF 3-9 & Oct-99 & 12100 & 1000 & 139.69 \\
\hline M11S & Oct-00 & -200 & 220 & 17.73 \\
\hline M12S & Mar-00 & 1400 & 400 & 14.96 \\
\hline M13S & Oct- 00 & -280 & 220 & 5.6 \\
\hline M14S & Oct-00 & 1200 & 400 & 14.59 \\
\hline USGS-20 & Jul-00 & -60 & 220 & 20.75 \\
\hline USGS-34 & Oct-99 & 1500 & 400 & 15.24 \\
\hline USGS-35 & Oct-00 & 470 & 280 & 6.75 \\
\hline USGS-36 & Oct-00 & 2300 & 400 & 37.81 \\
\hline USGS-37 & Oct-99 & 8500 & 800 & 132.48 \\
\hline USGS-38 & Oct-99 & 6600 & 800 & 158.41 \\
\hline USGS-39 & Oct- 00 & 400 & 280 & 6.46 \\
\hline USGS-40 & Oct-99 & 1600 & 400 & 16.48 \\
\hline USGS-41 & Oct-00 & 620 & 300 & 17.94 \\
\hline USGS-42 & Oct-00 & 180 & 260 & 15 \\
\hline USGS-43 & Oct-99 & 2100 & 400 & 21.52 \\
\hline USGS-44 & Oct-99 & 30 & 260 & 14.78 \\
\hline USGS-45 & Oct- 00 & 290 & 280 & 16.19 \\
\hline USGS-46 & Oct-99 & 950 & 340 & 15.22 \\
\hline USGS-47 & Oct-99 & 1900 & 400 & 20.17 \\
\hline USGS-48 & Oct-00 & 950 & 320 & 19.35 \\
\hline USGS-51 & Oct-00 & 11700 & 1000 & 165.88 \\
\hline USGS-51 (Dup) & Oct-00 & 14000 & 1200 & 147.21 \\
\hline USGS-52 & Oct-00 & 1500 & 400 & 24.96 \\
\hline
\end{tabular}


Table 3. (continued).

\begin{tabular}{lcccc}
\hline Well & $\begin{array}{c}\text { Date } \\
\text { Sampled }\end{array}$ & $\begin{array}{c}\text { Tritium } \\
(\mathrm{pCi} / \mathrm{L})\end{array}$ & $\begin{array}{c}+/- \\
\text { uncertainty }\end{array}$ & $\begin{array}{c}\text { Chloride } \\
(\mathrm{mg} / \mathrm{L})\end{array}$ \\
\hline USGS-57 & Jan-00 & 6200 & 600 & 118.73 \\
USGS-59 & Oct-00 & 890 & 320 & 21.32 \\
USGS-67 & Oct-00 & 7800 & 800 & 148.03 \\
USGS-77 & Oct-00 & 1500 & 1200 & 143.23 \\
USGS-82 & Sep-00 & -210 & 220 & 16.11 \\
USGS-83 & Aug-00 & 55.6 & 78.6 & 10.8 WAG 4 \\
USGS-83 & Apr-00 & -110 & 100 & 10.13 USGS \\
USGS-84 & Oct-99 & 1700 & 400 & 6.9 \\
USGS-85 & Oct-00 & 2900 & 400 & 34.92 \\
USGS-104 & Oct-00 & 1050 & 340 & 11.79 \\
USGS-106 & Oct-00 & 1110 & 180 & 14.03 \\
USGS-107 & Apr-00 & -50 & 100 & 21.63 \\
USGS-111 & Oct-00 & 3600 & 600 & 97.61 \\
USGS-112 & Oct-00 & 4600 & 600 & 114.3 \\
USGS-113 & Oct-00 & 4500 & 600 & 170.5 \\
USGS-115 & Oct-00 & 1200 & 400 & 34.49 \\
USGS-116 & Oct-00 & 2600 & 400 & 94.78 \\
USGS-121 & Oct-00 & -170 & 220 & 11.26 \\
USGS-123 & Sep-00 & 7100 & 800 & 75.61 \\
\hline & & & &
\end{tabular}




\section{Appendix A}

\section{Water-Level Measurement Data and Borehole Deviation}

Correction Values 
A-2 


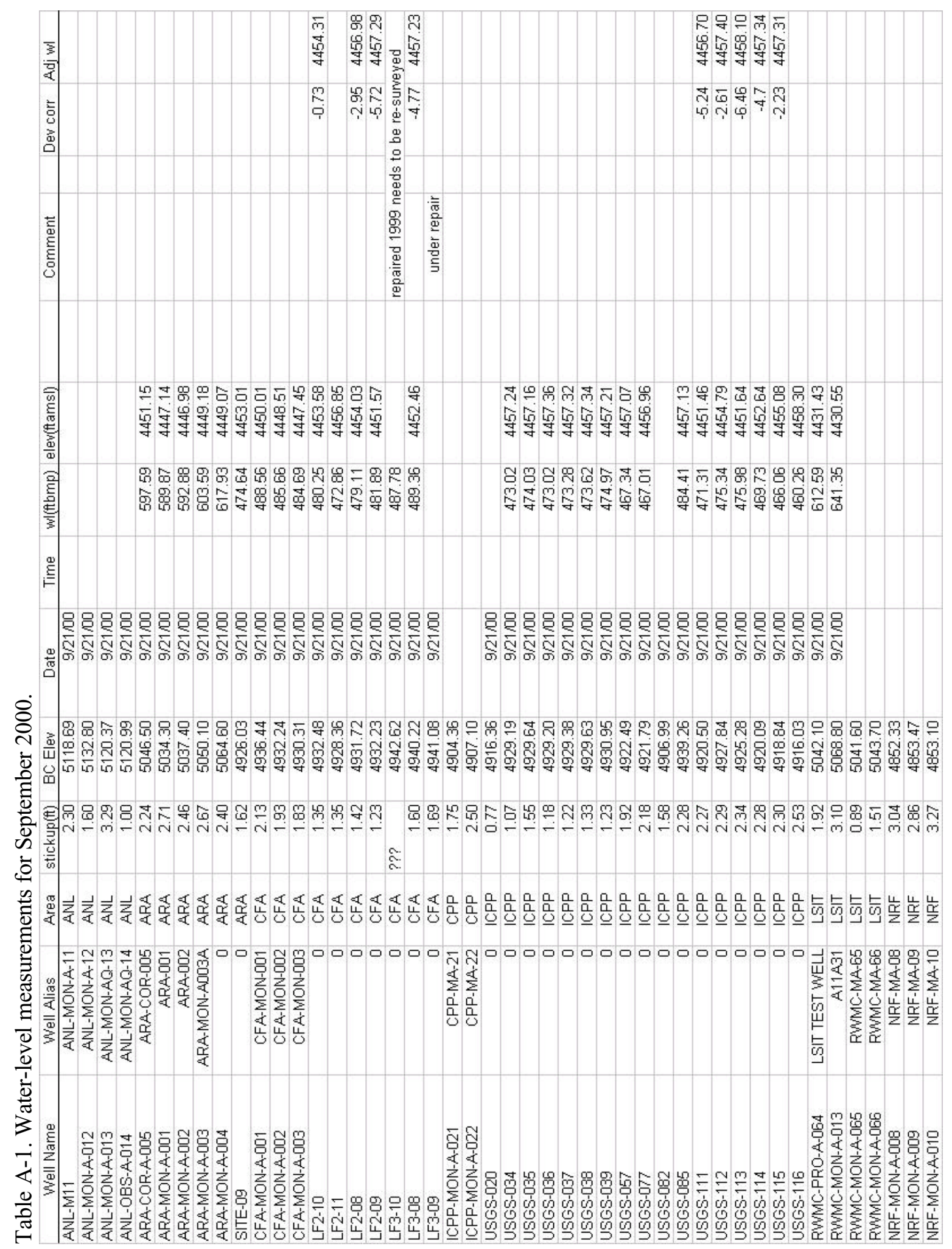




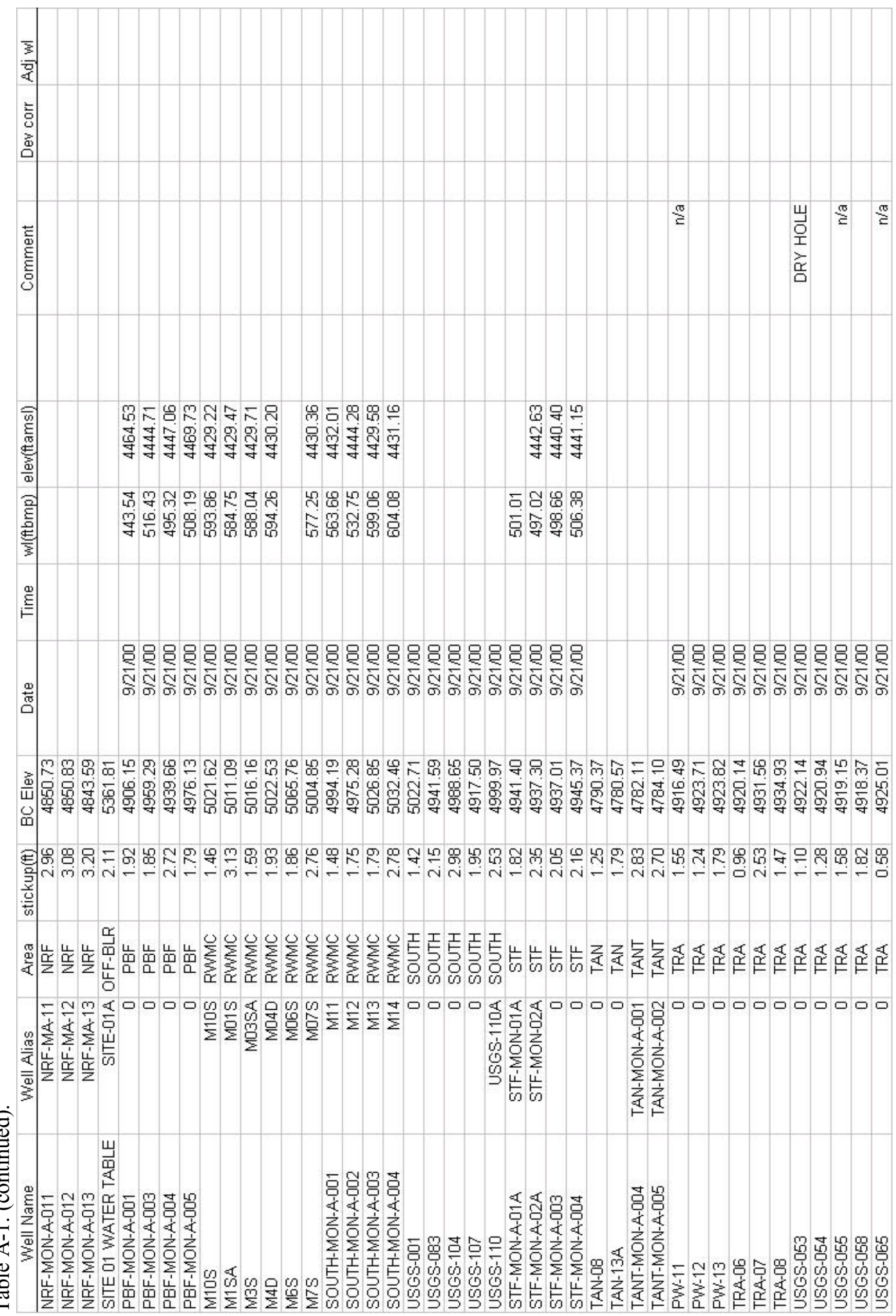




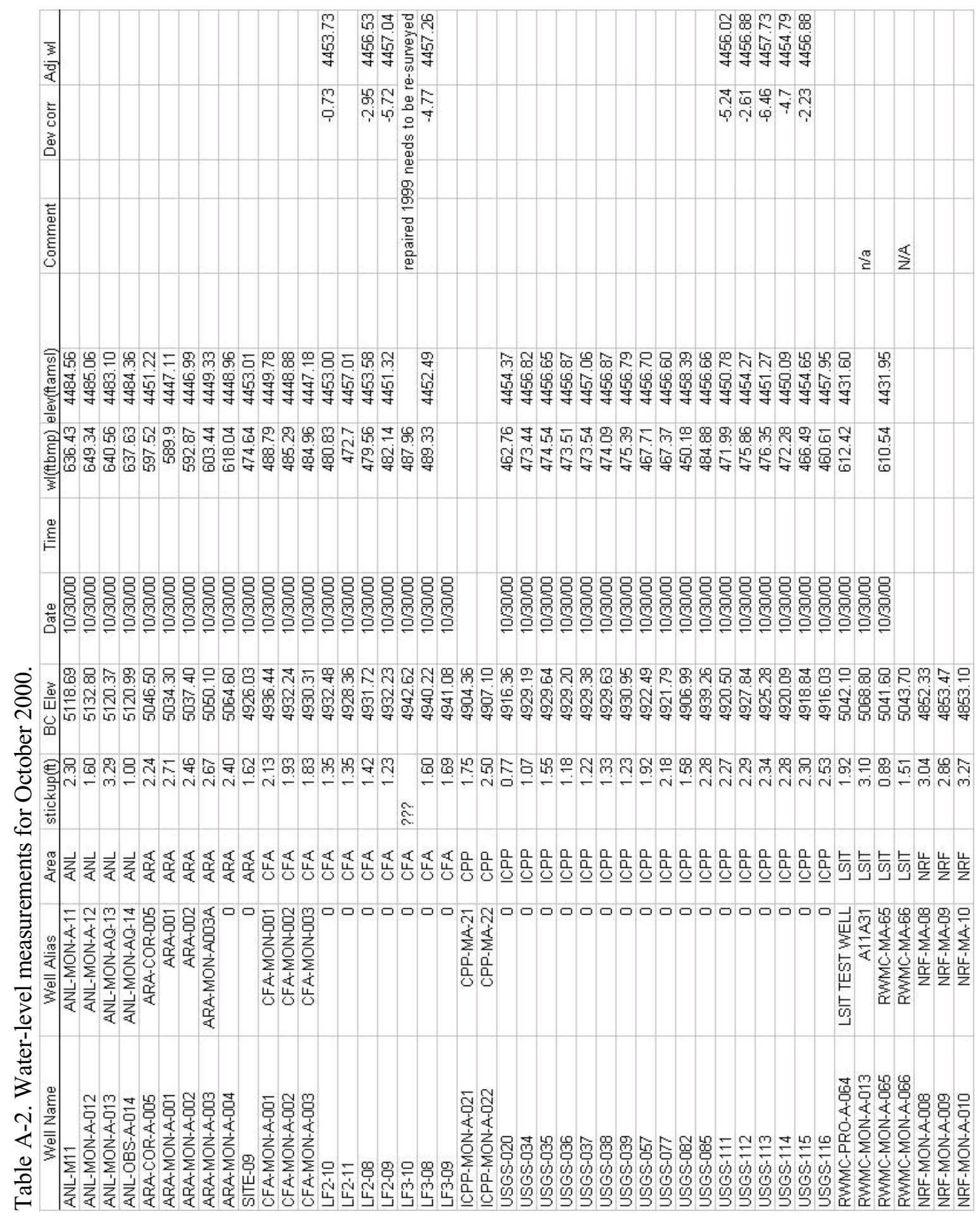




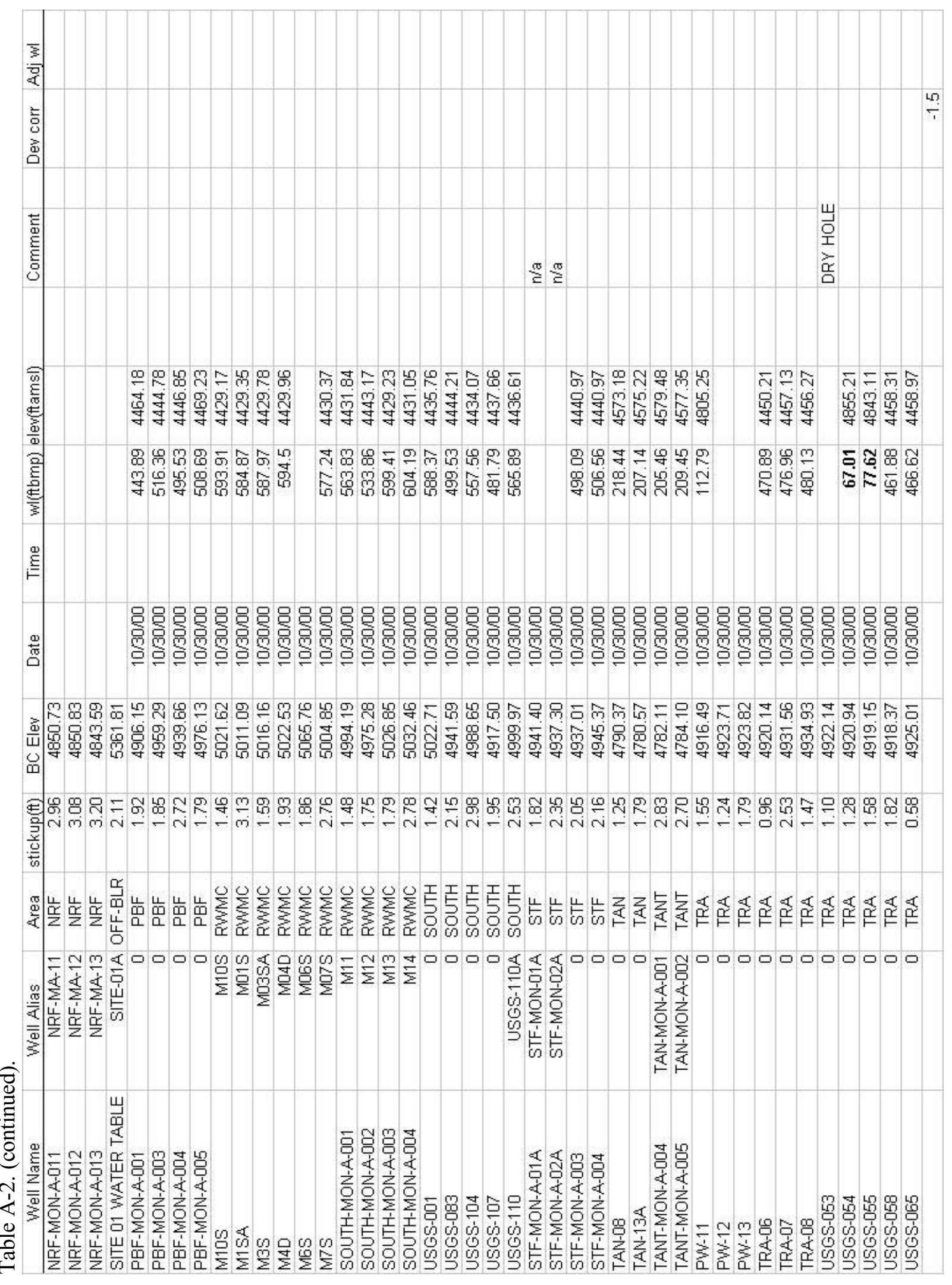




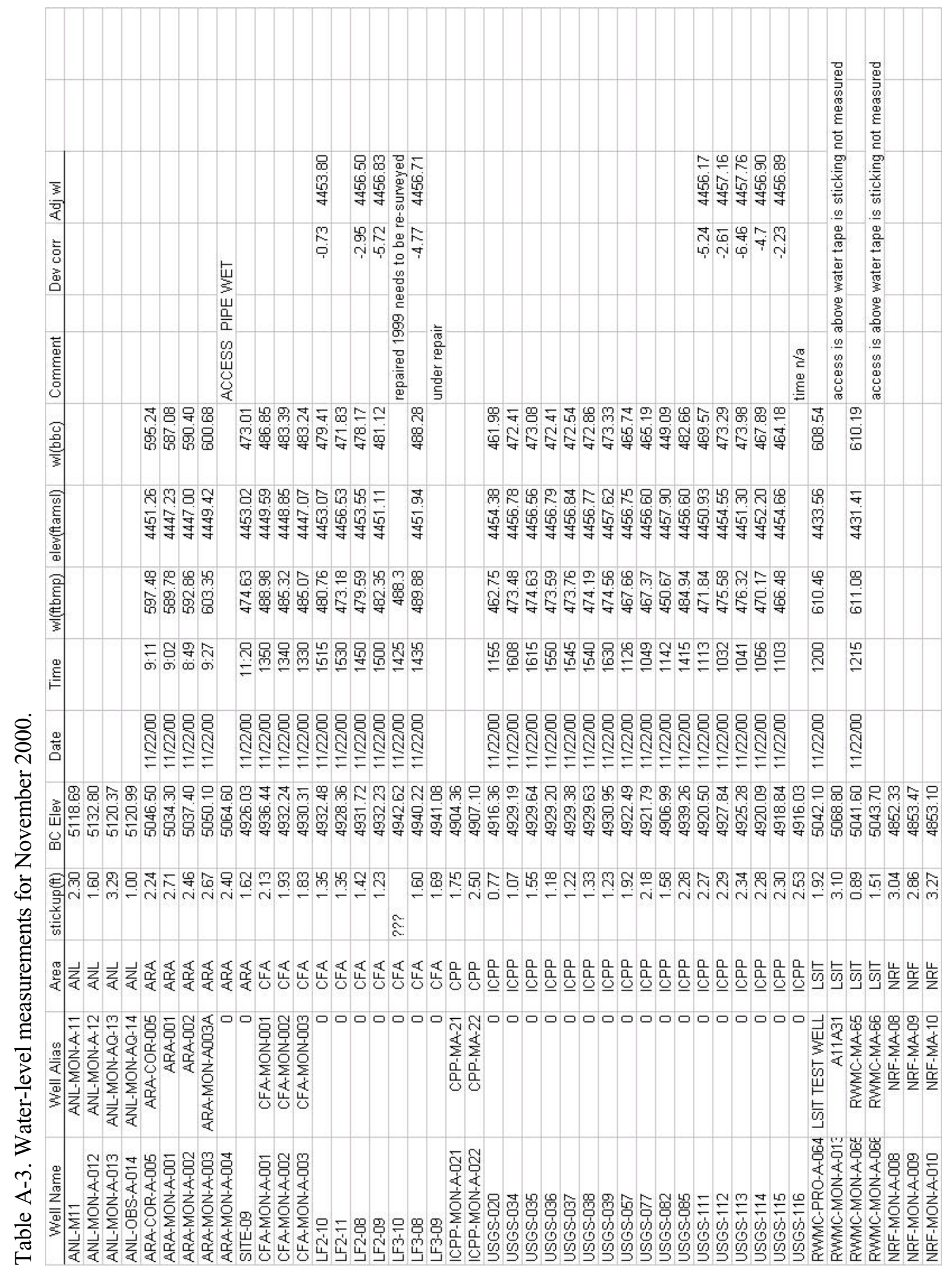




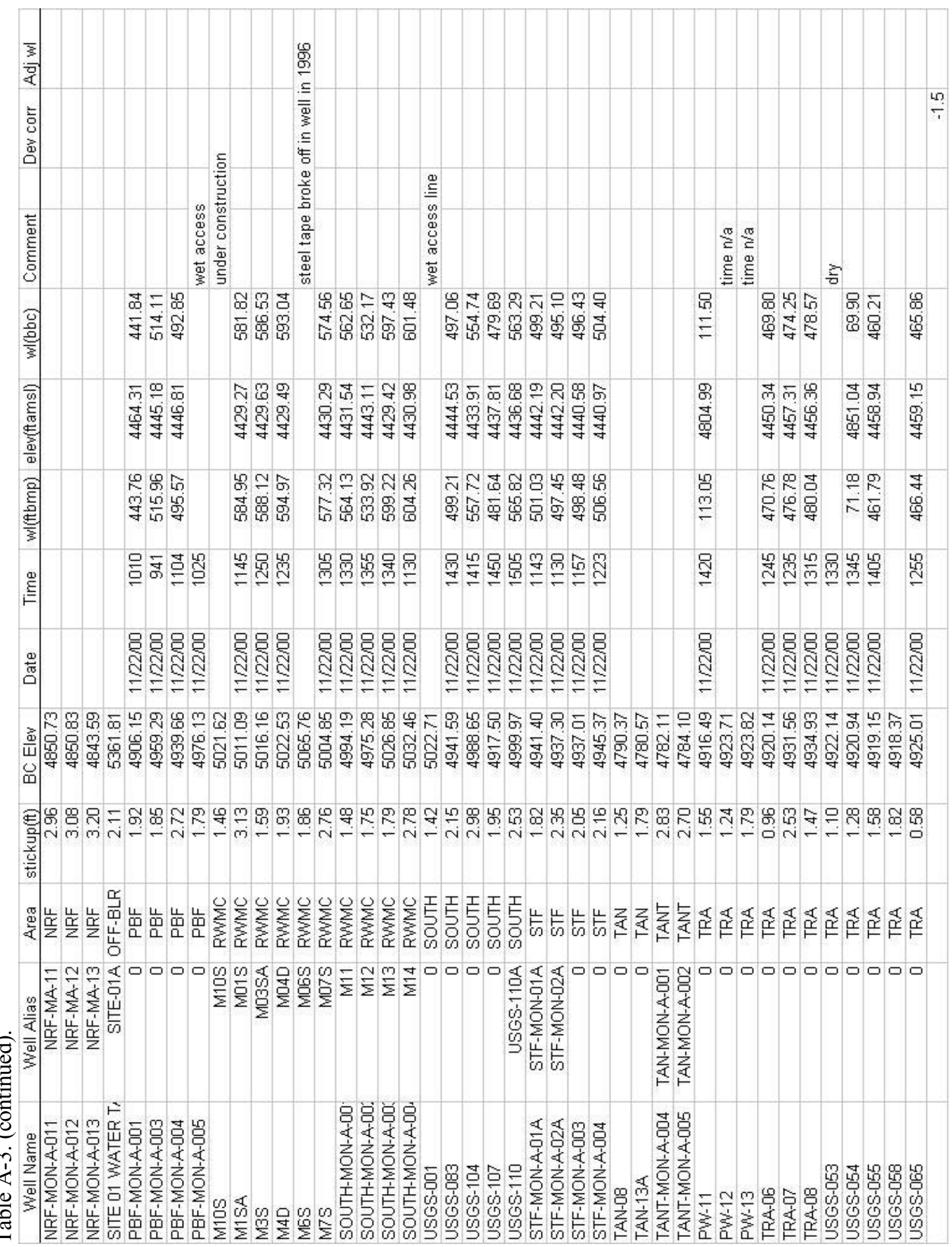




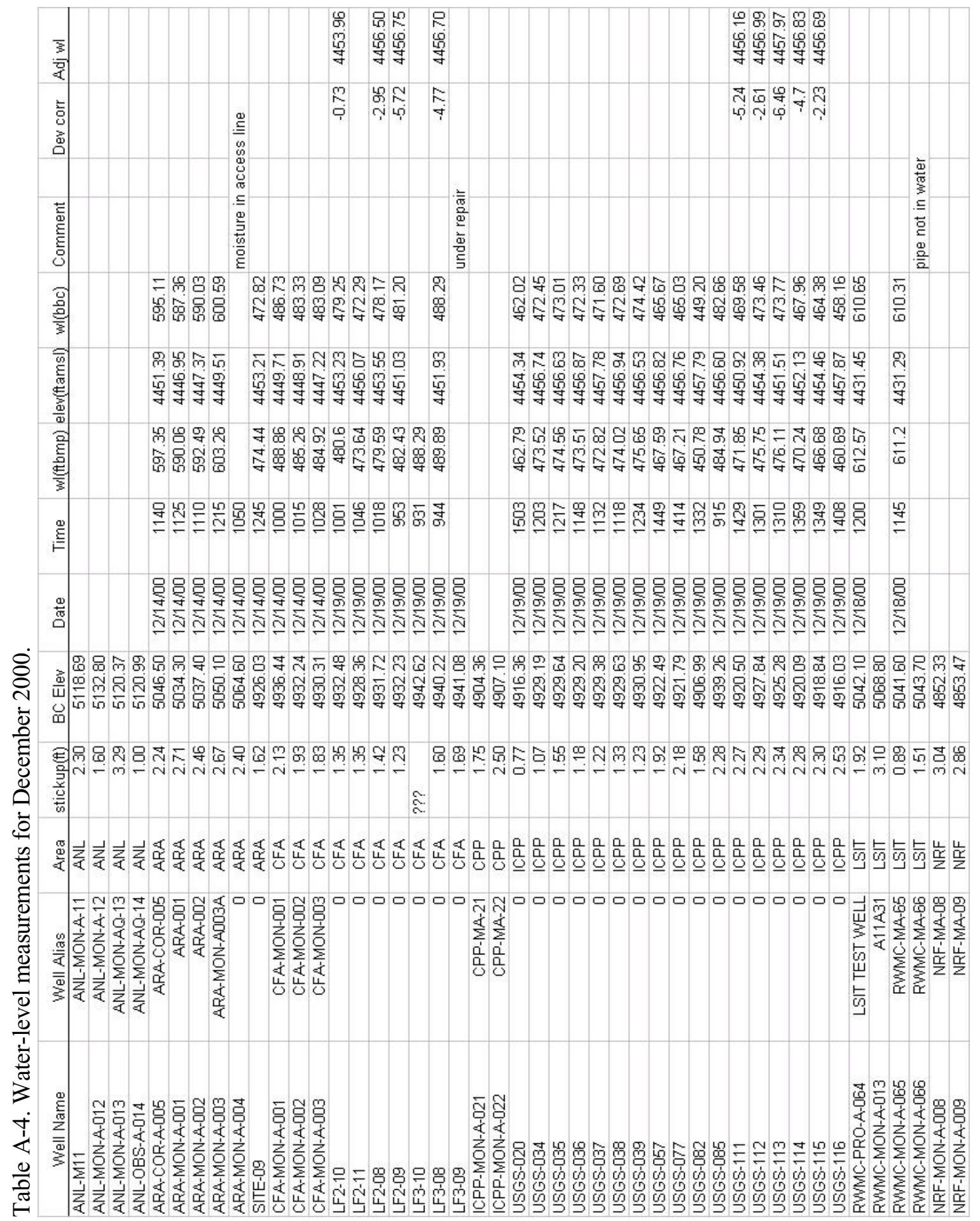




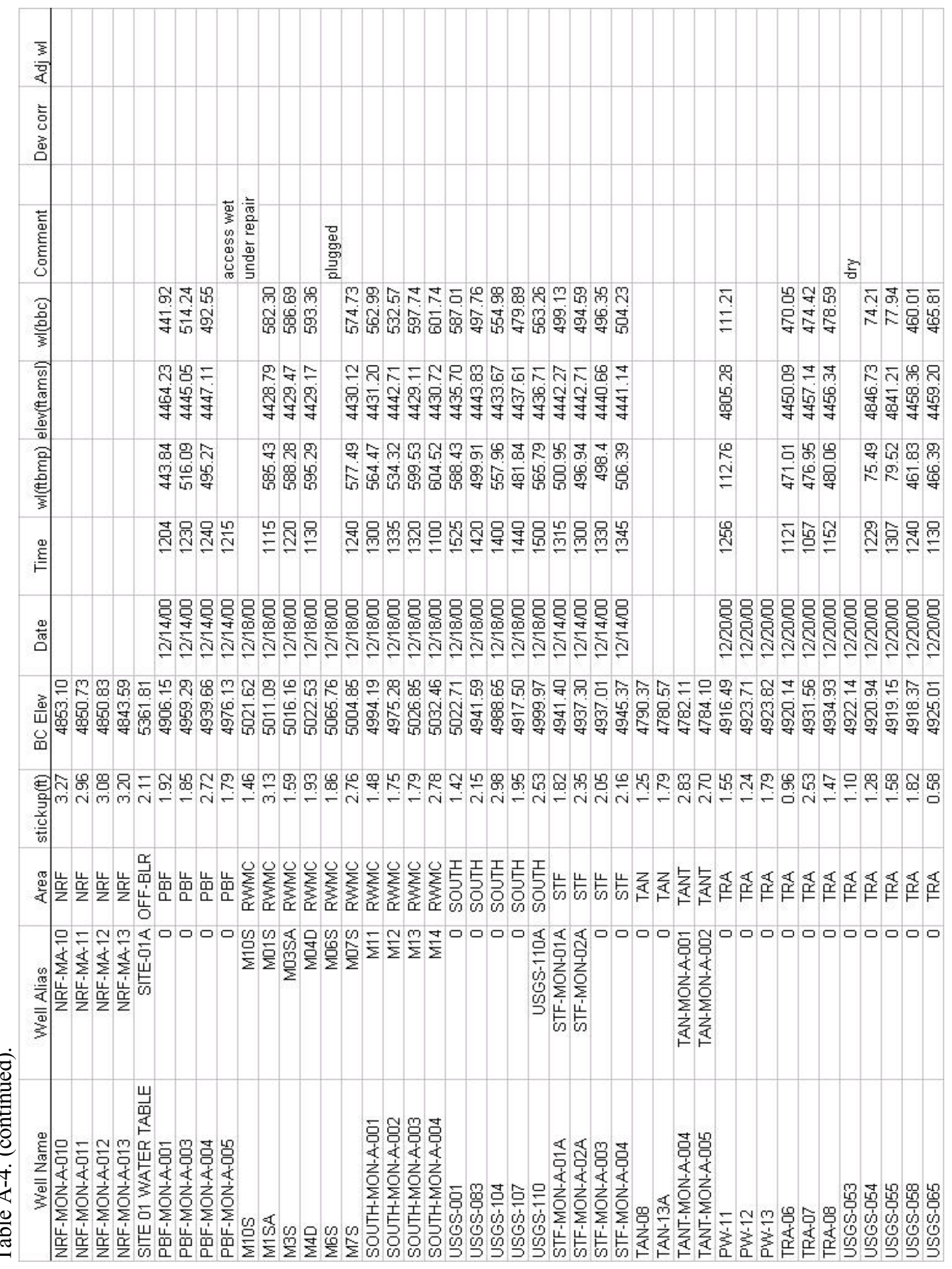




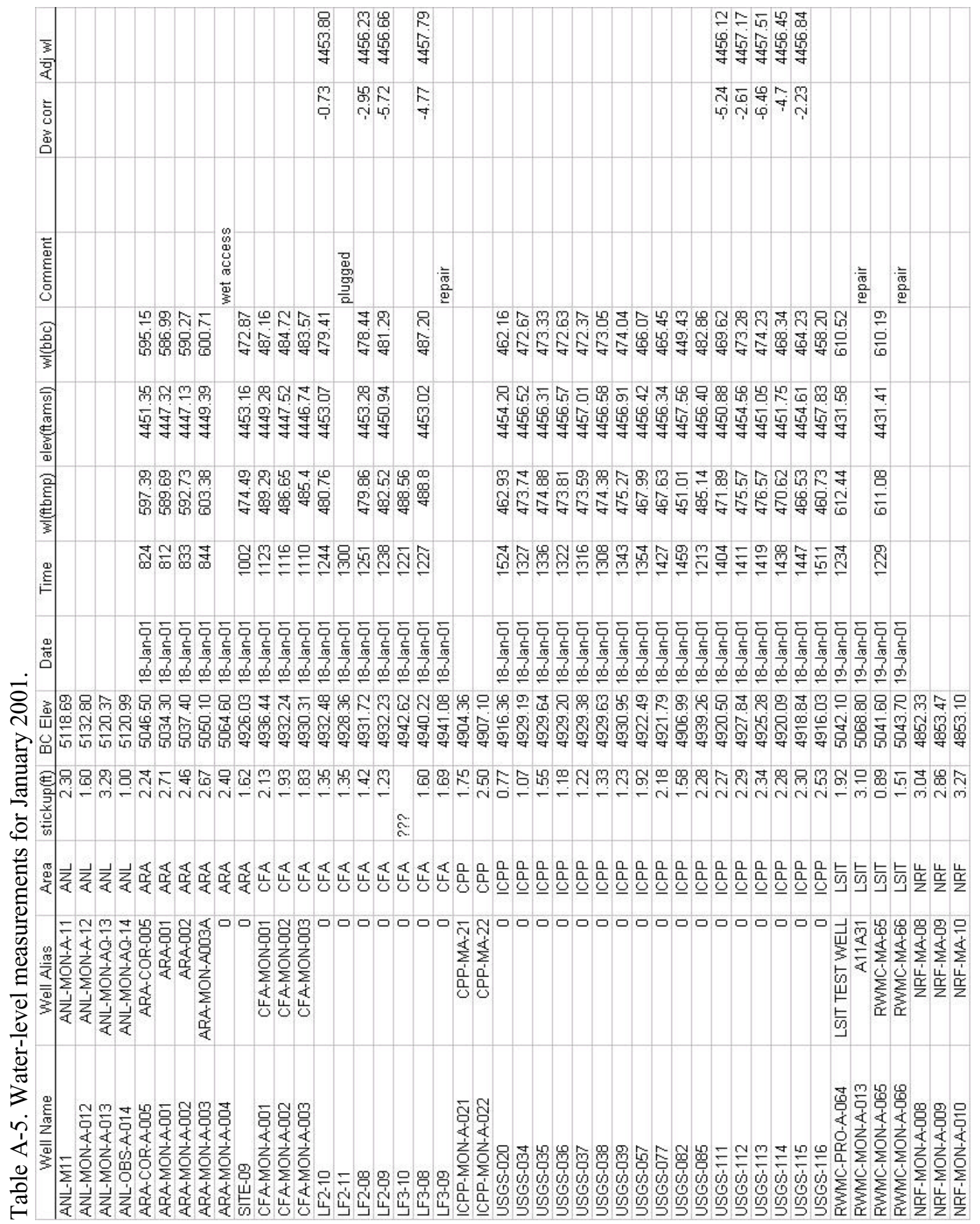




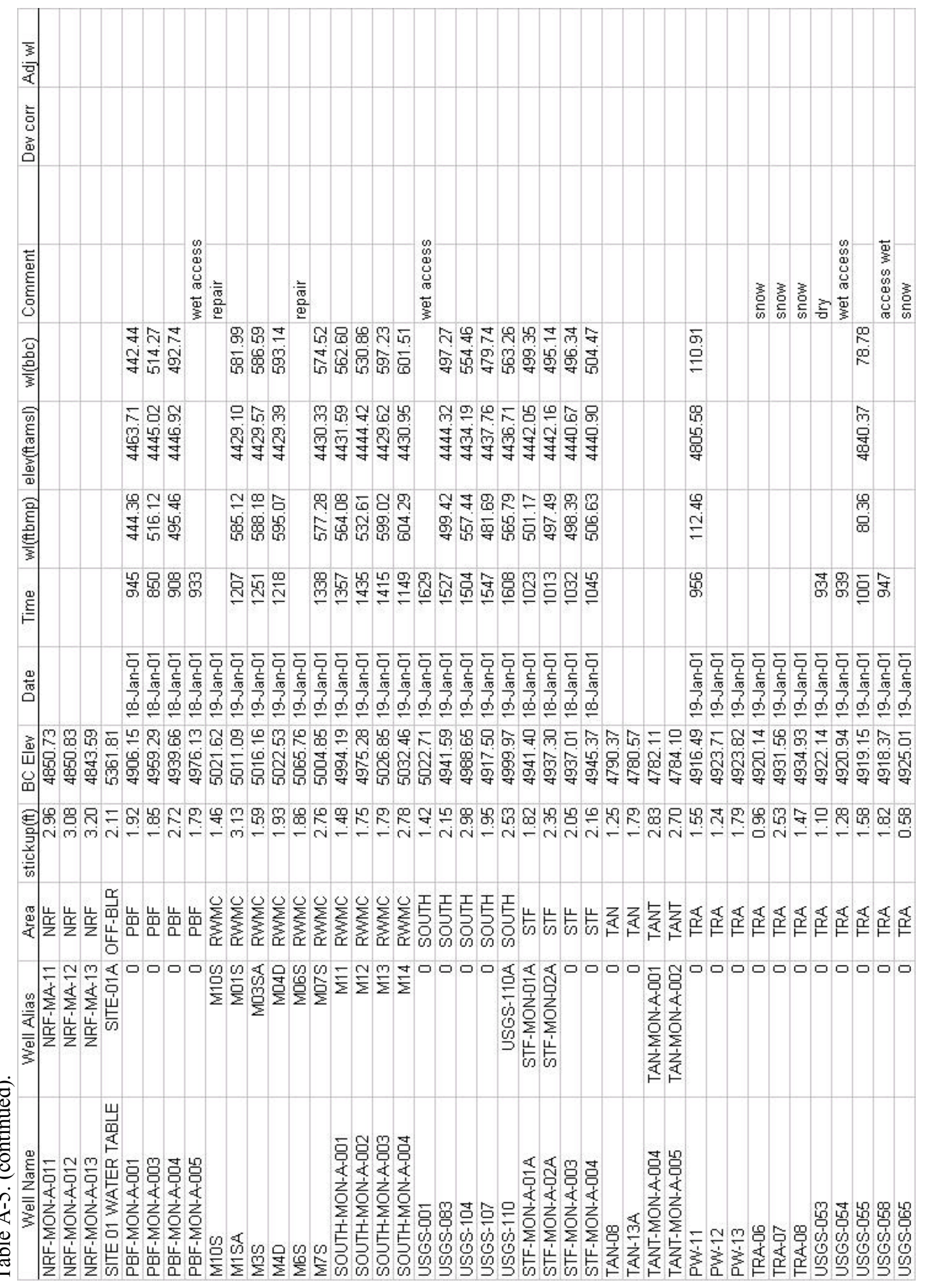




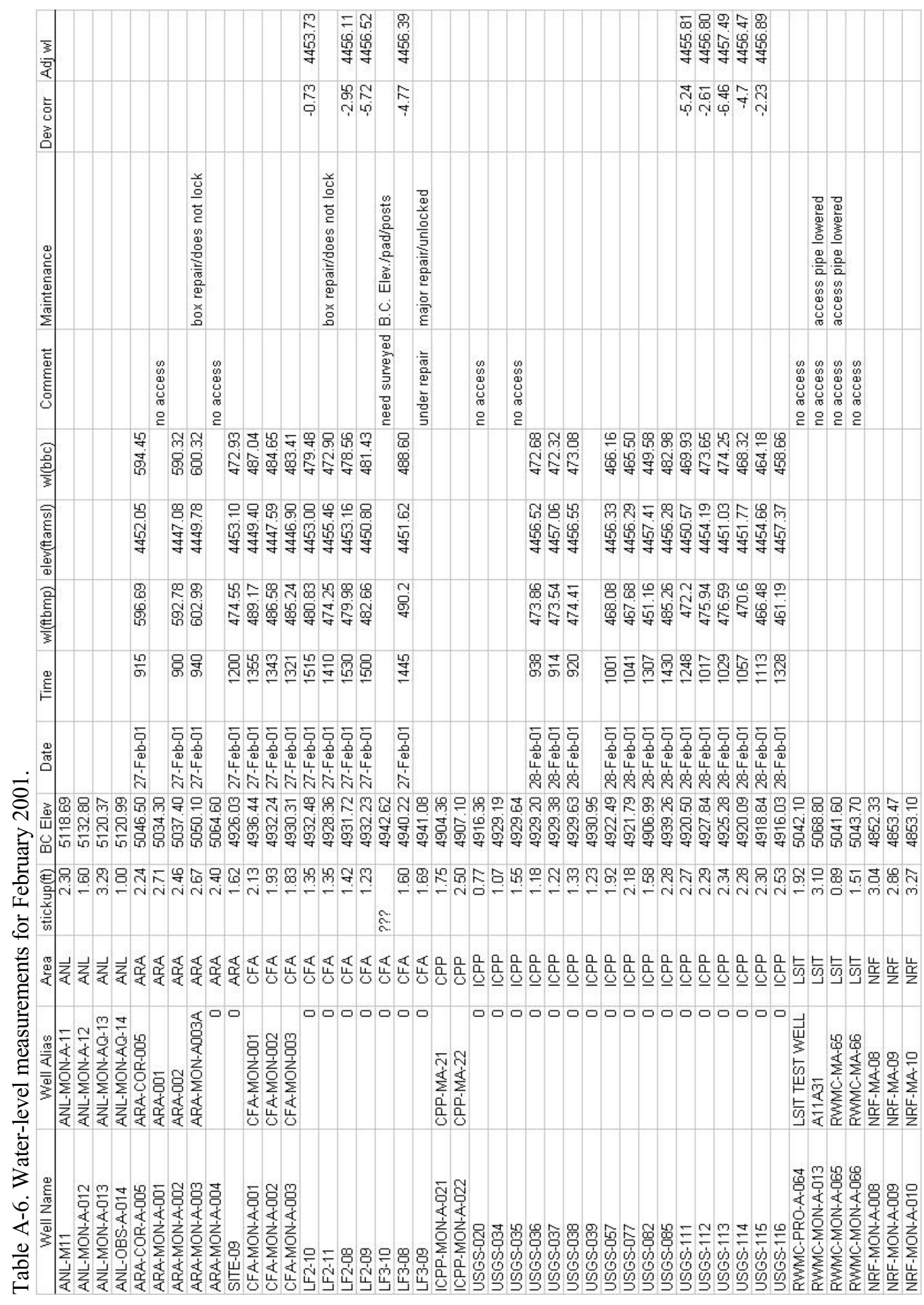




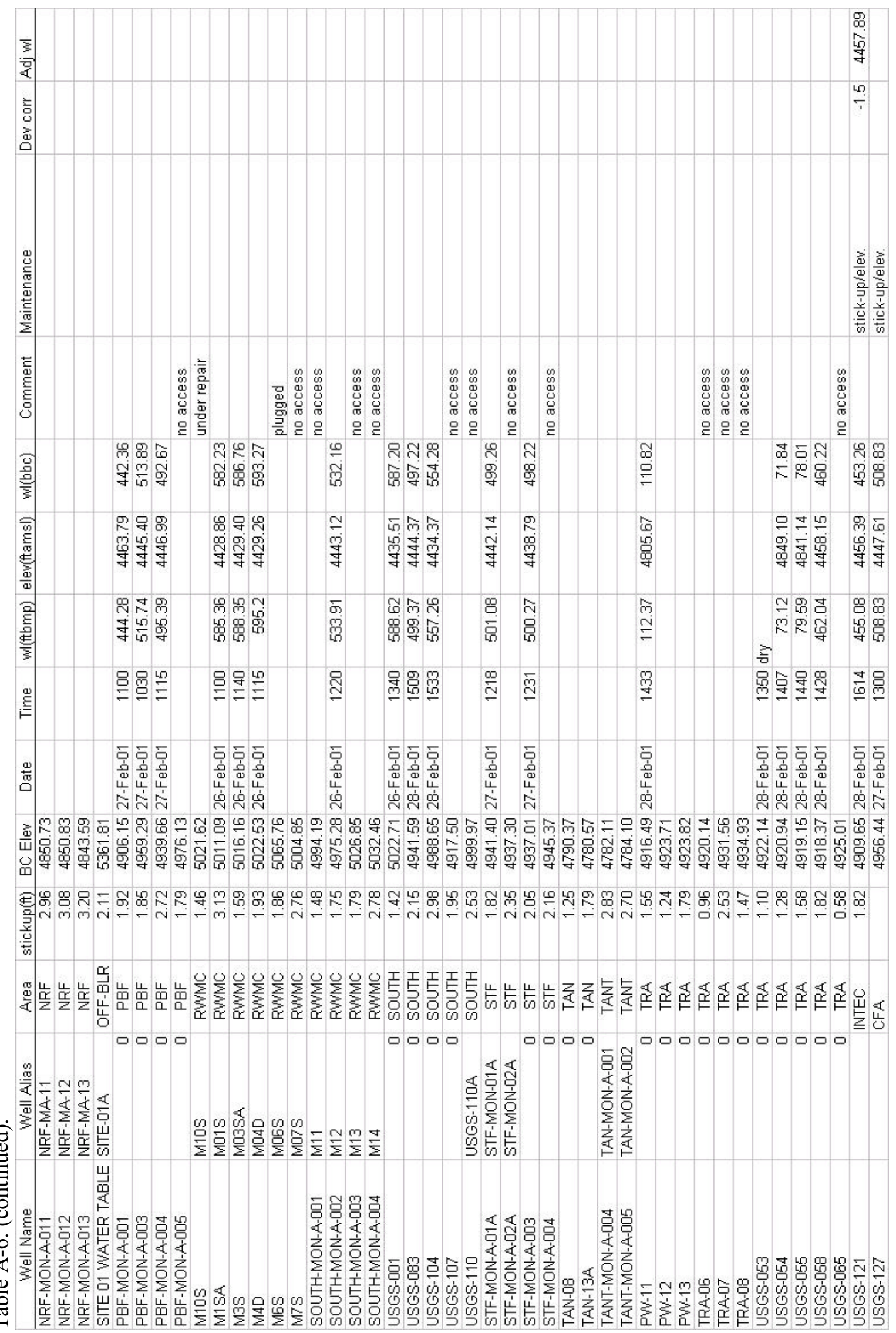




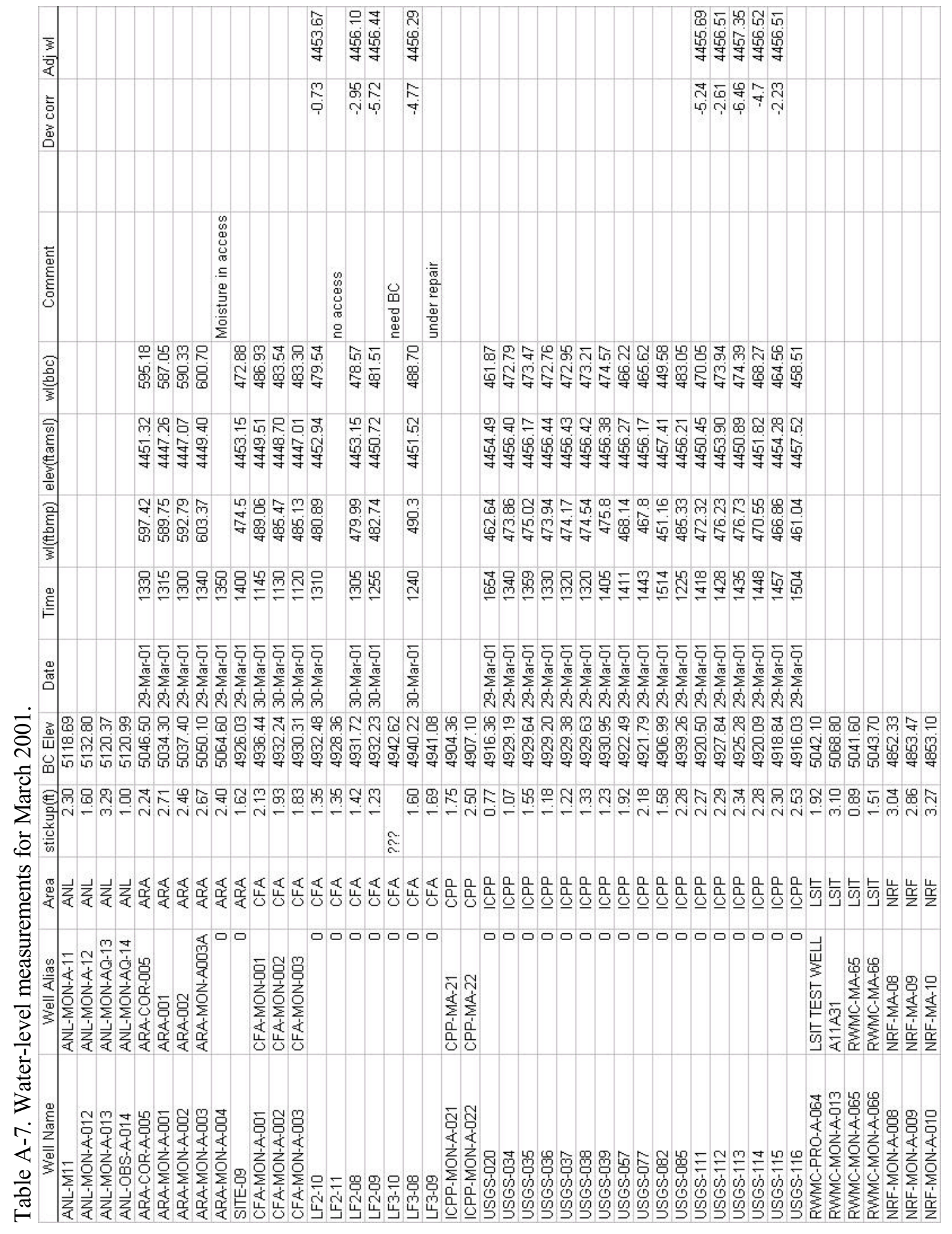




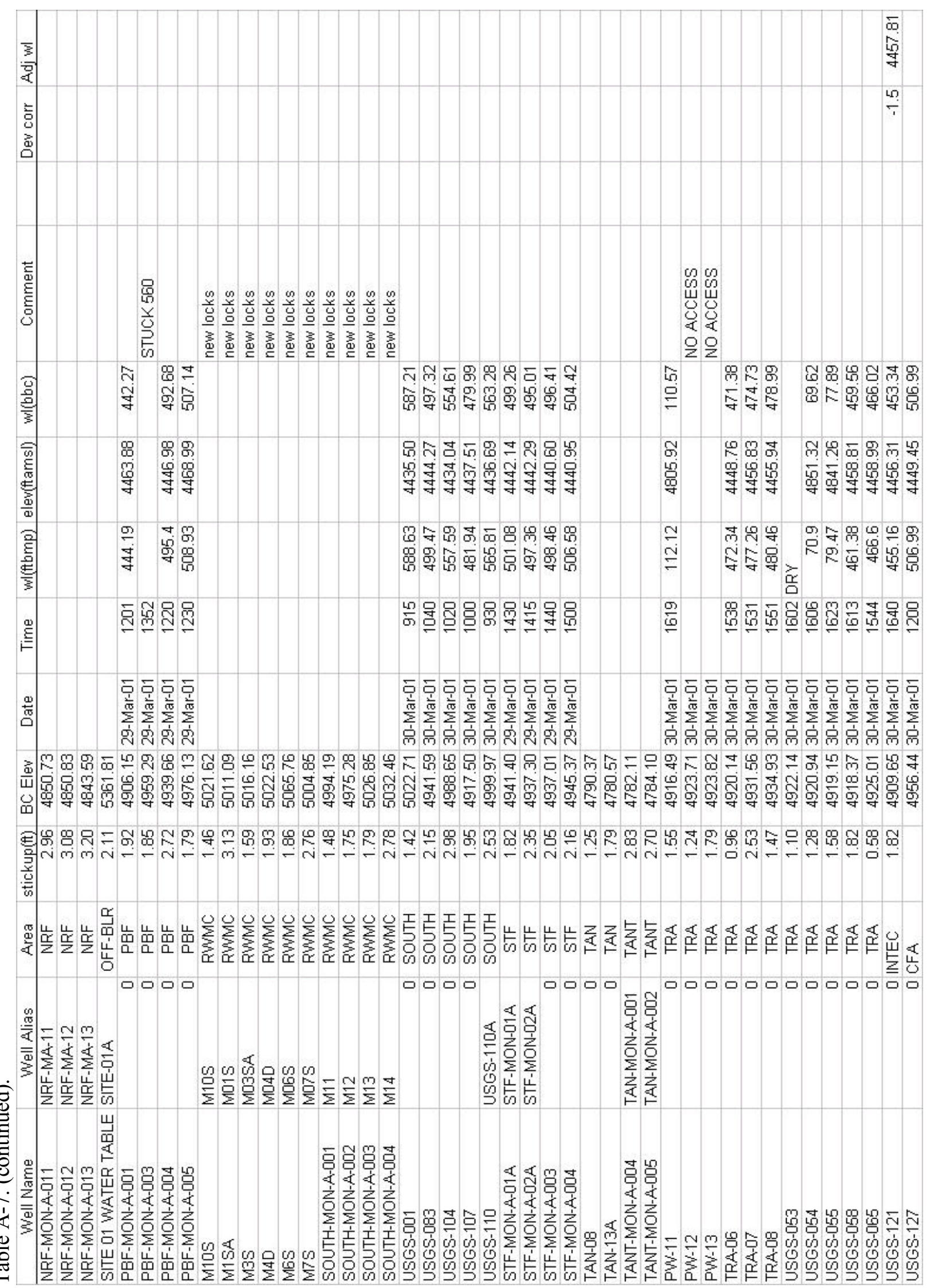




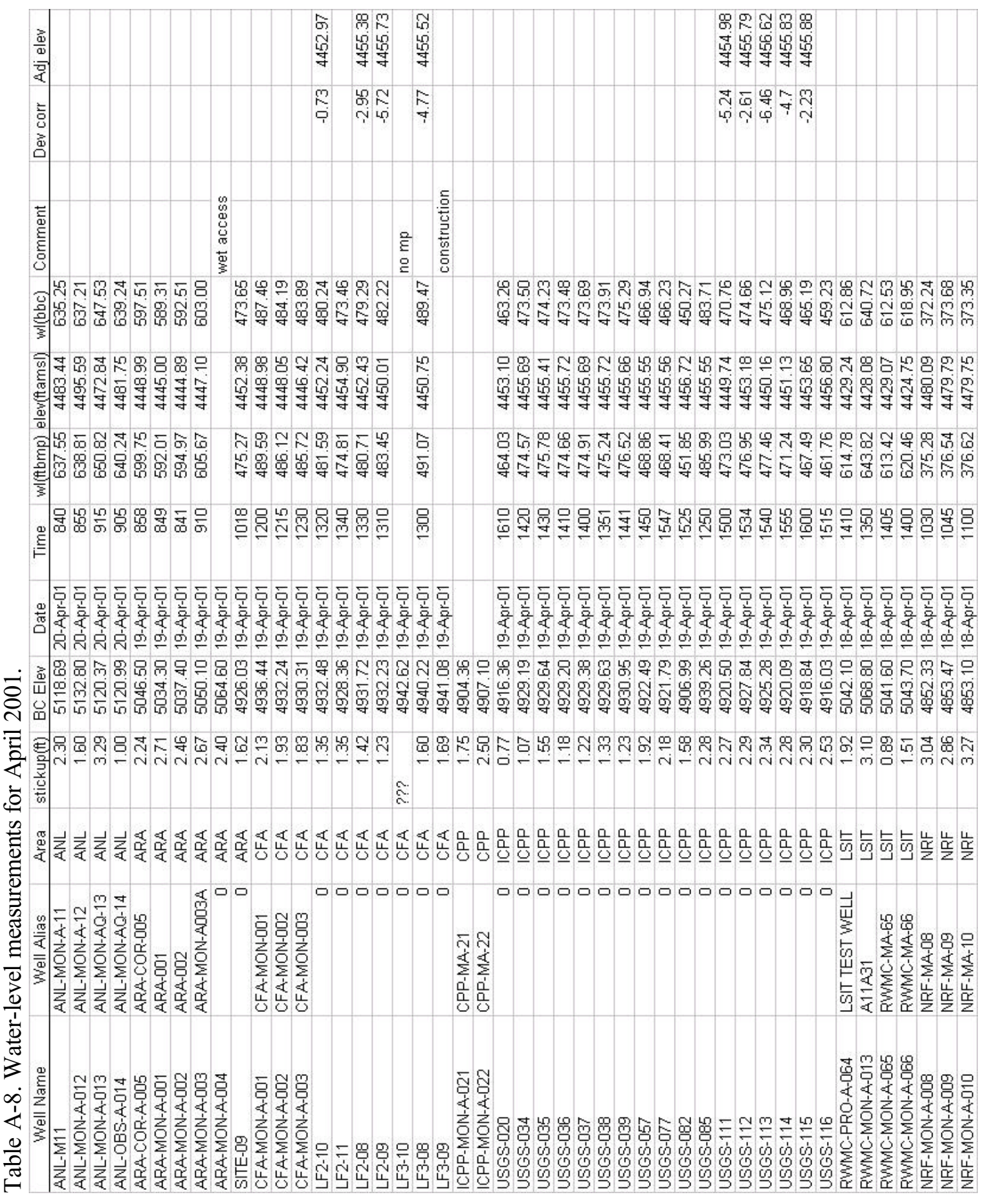




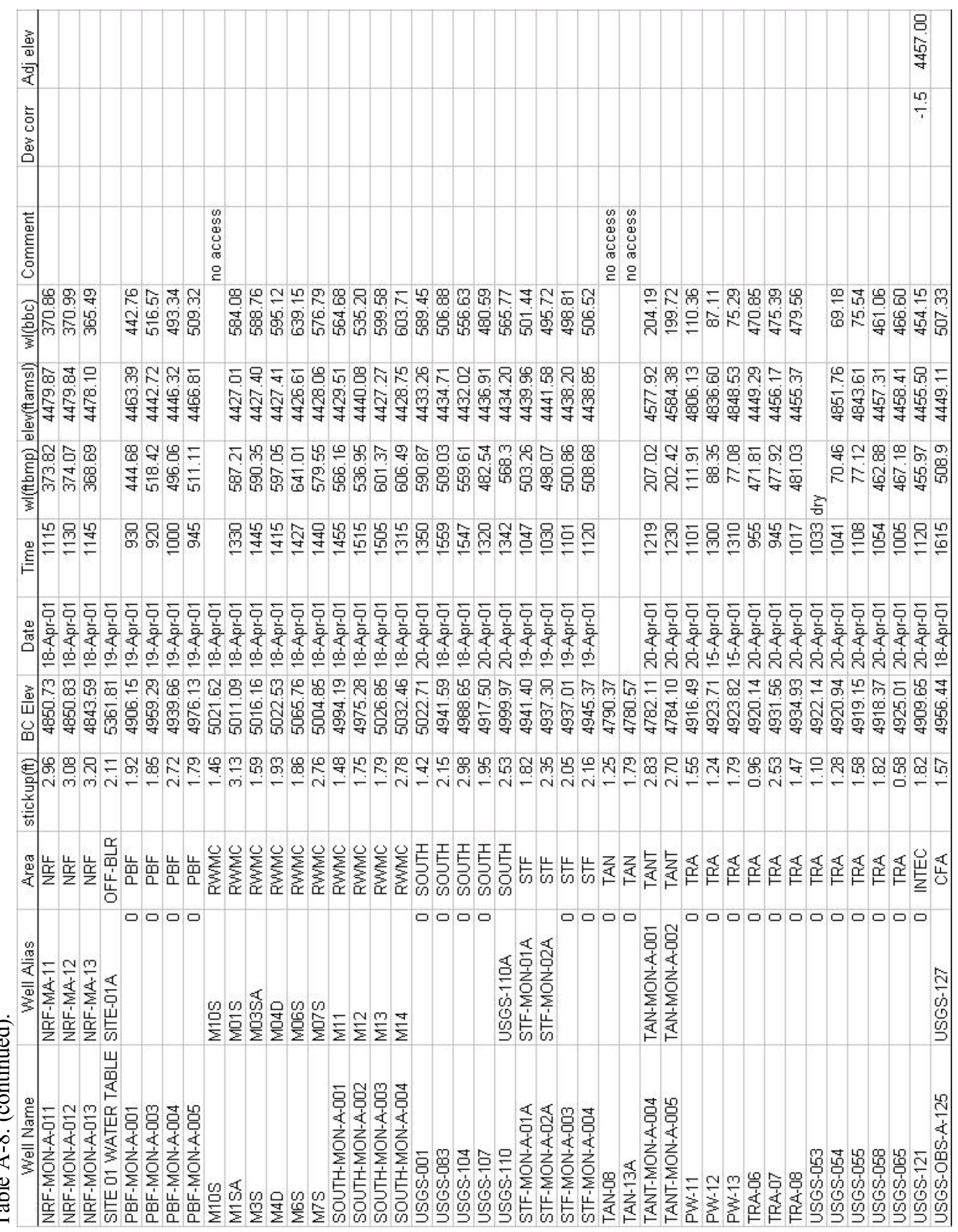




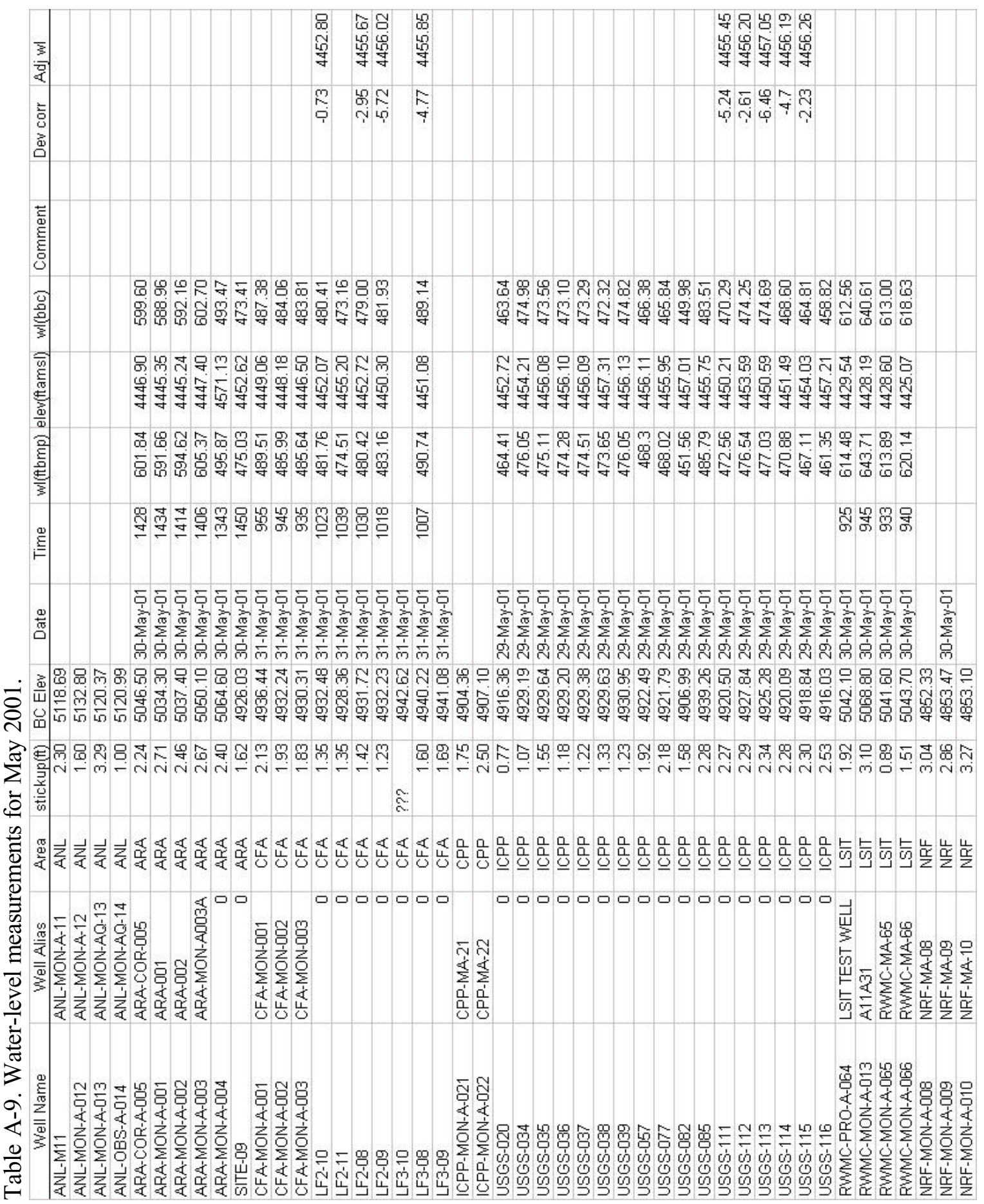




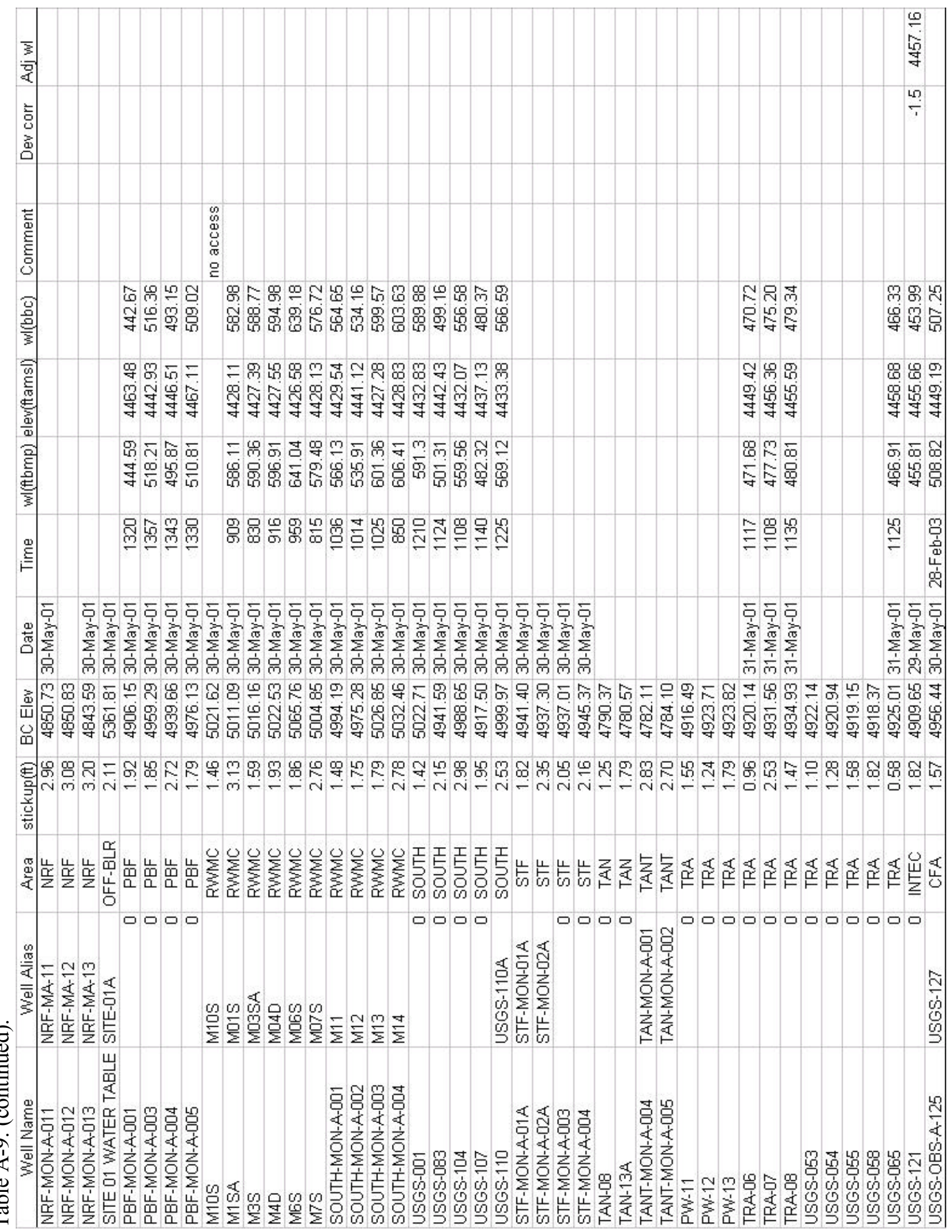




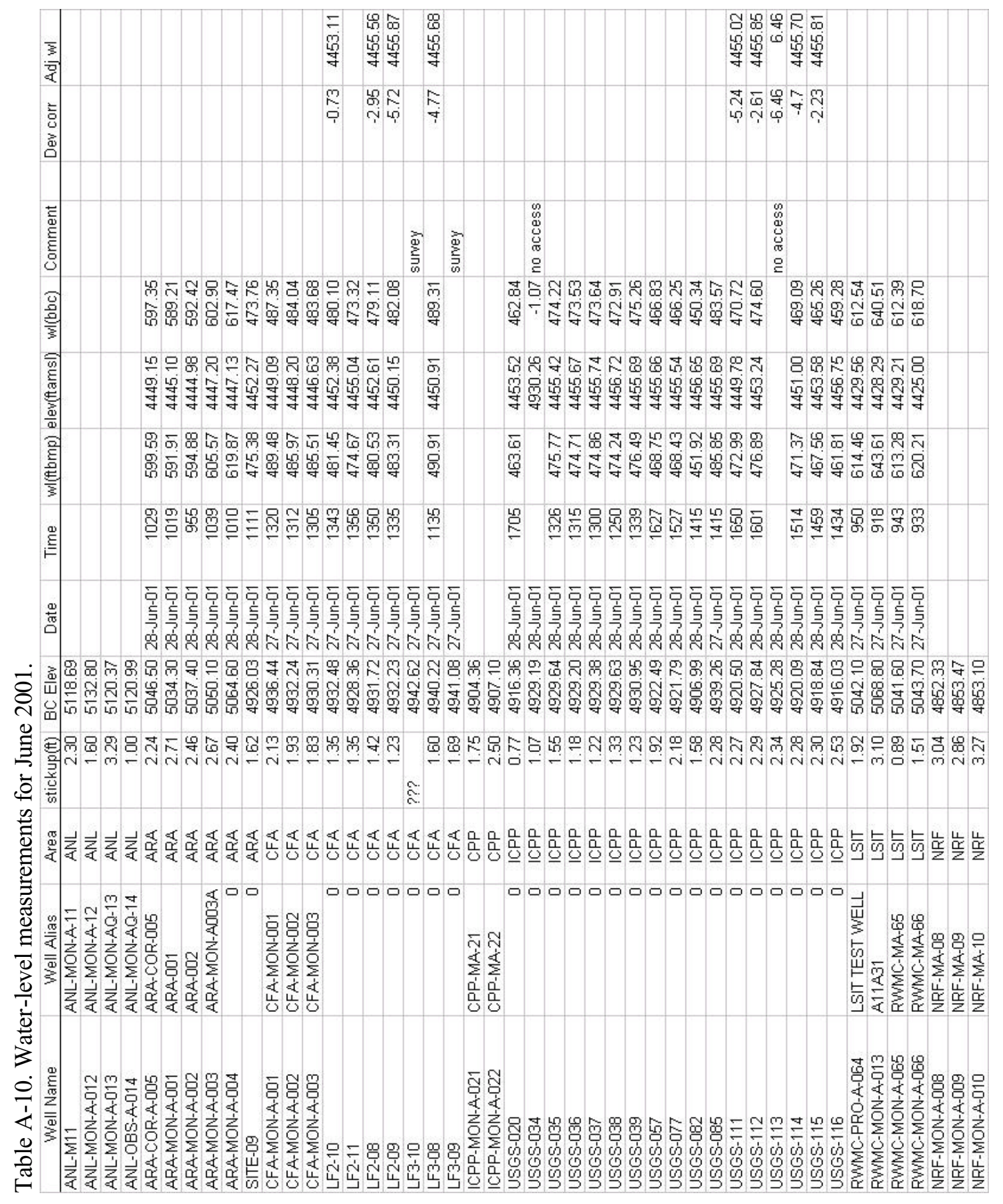




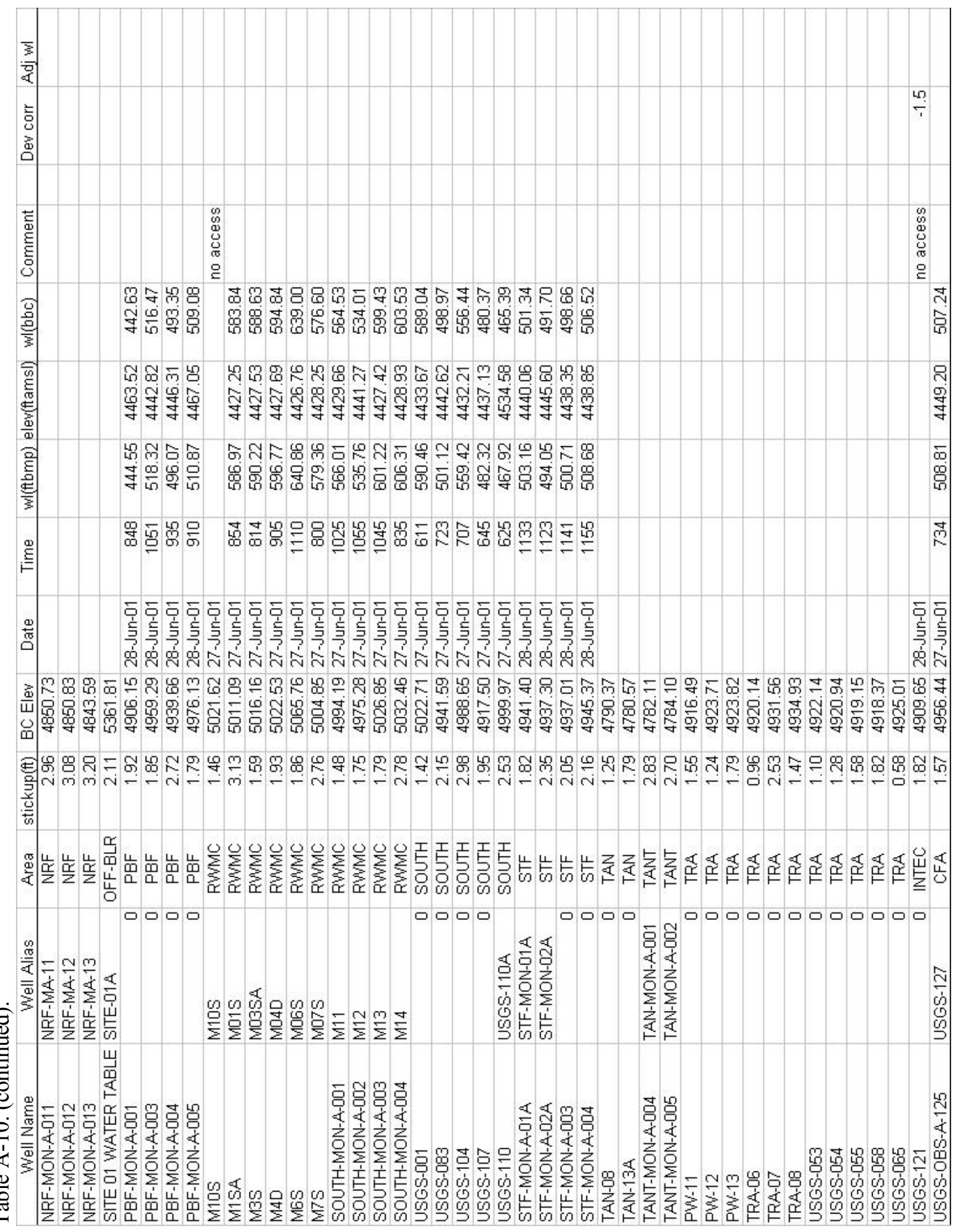




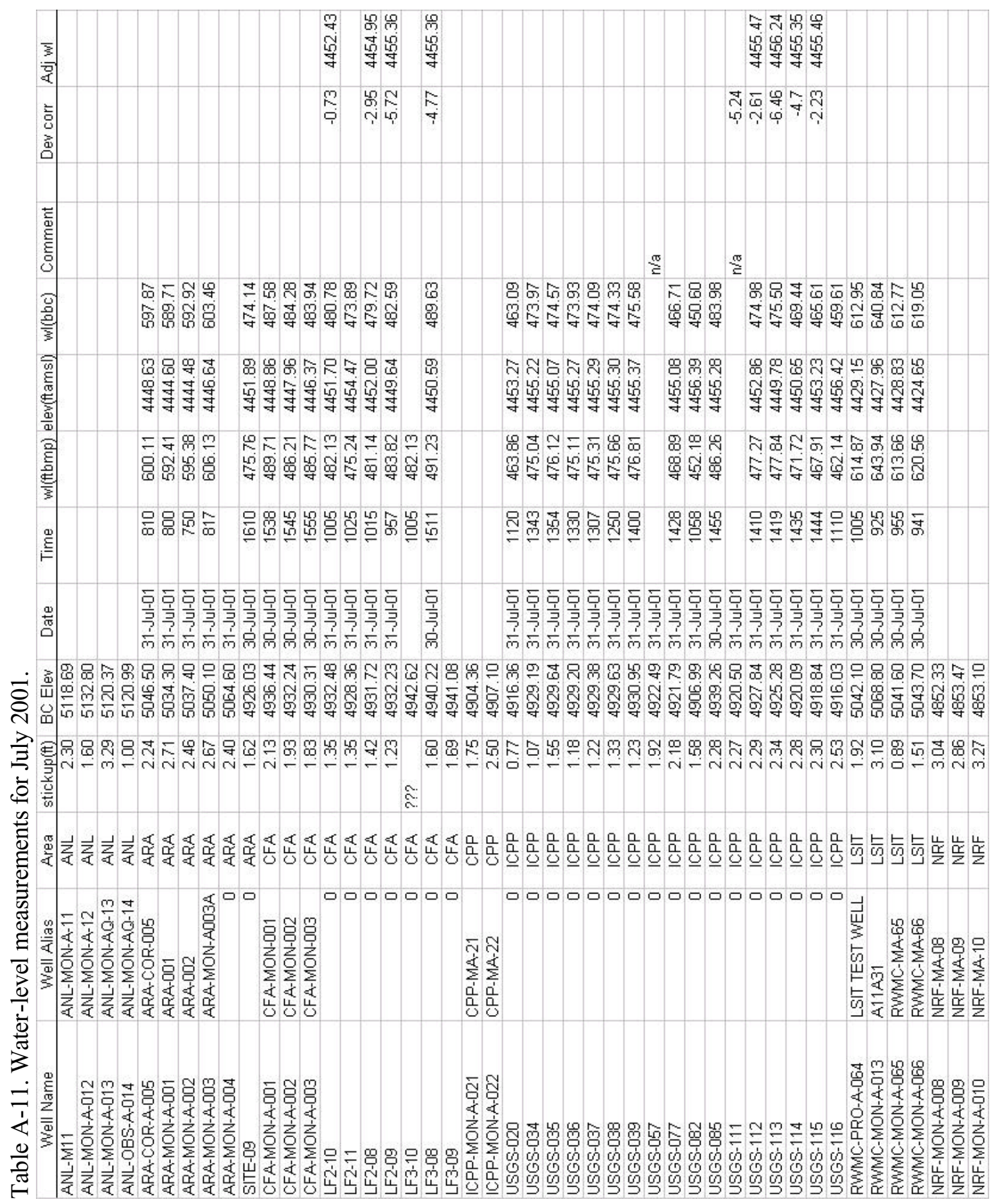




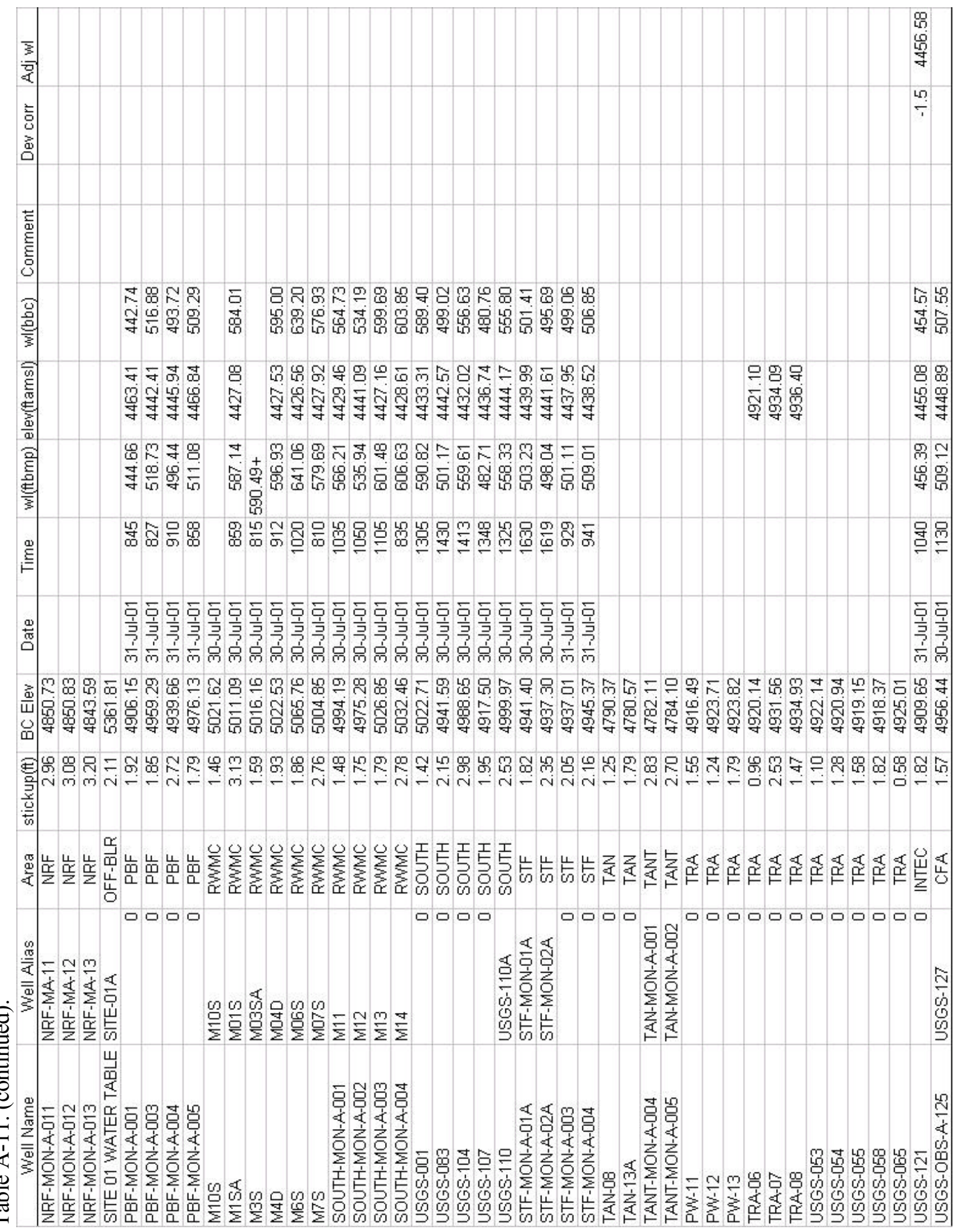




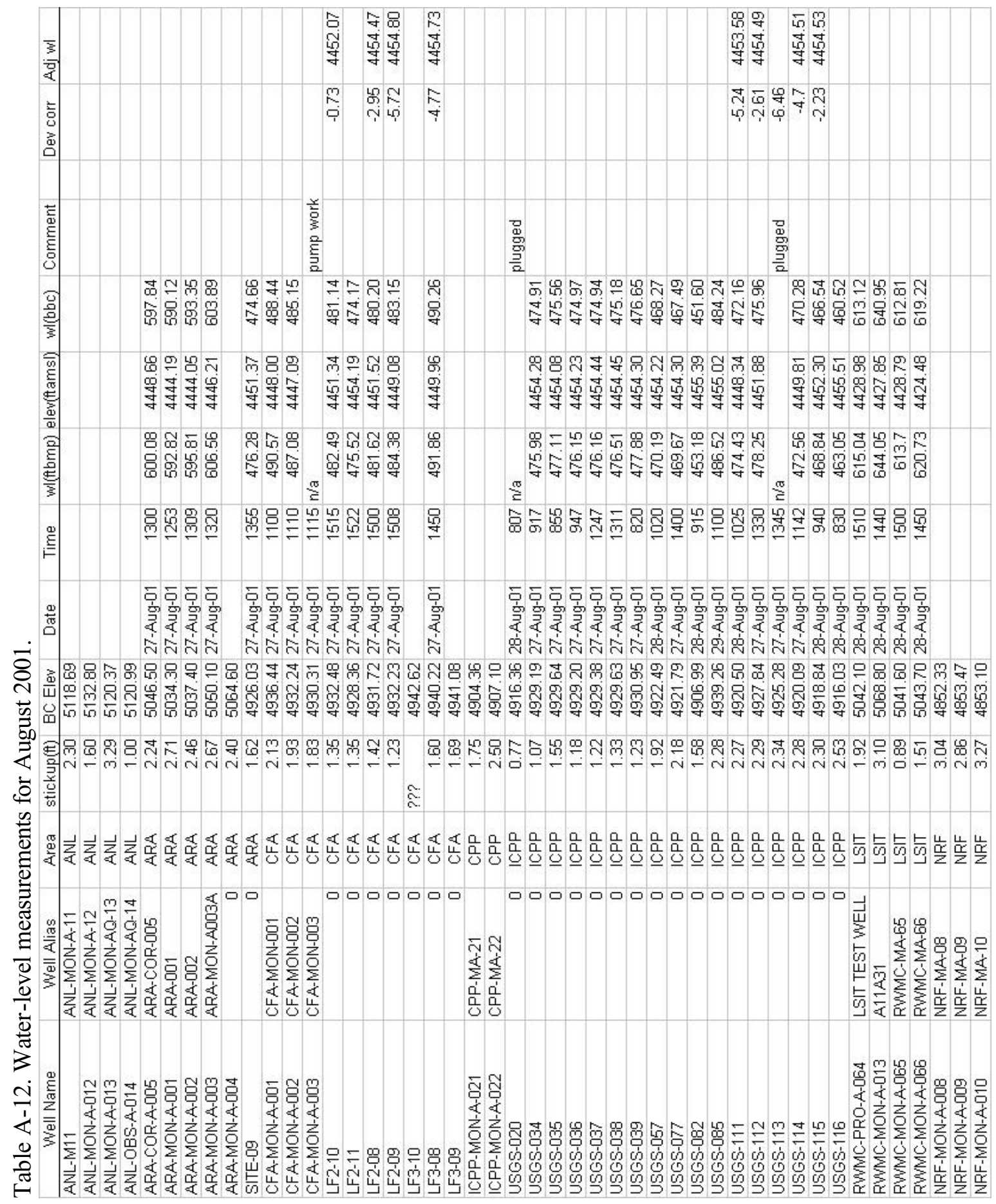




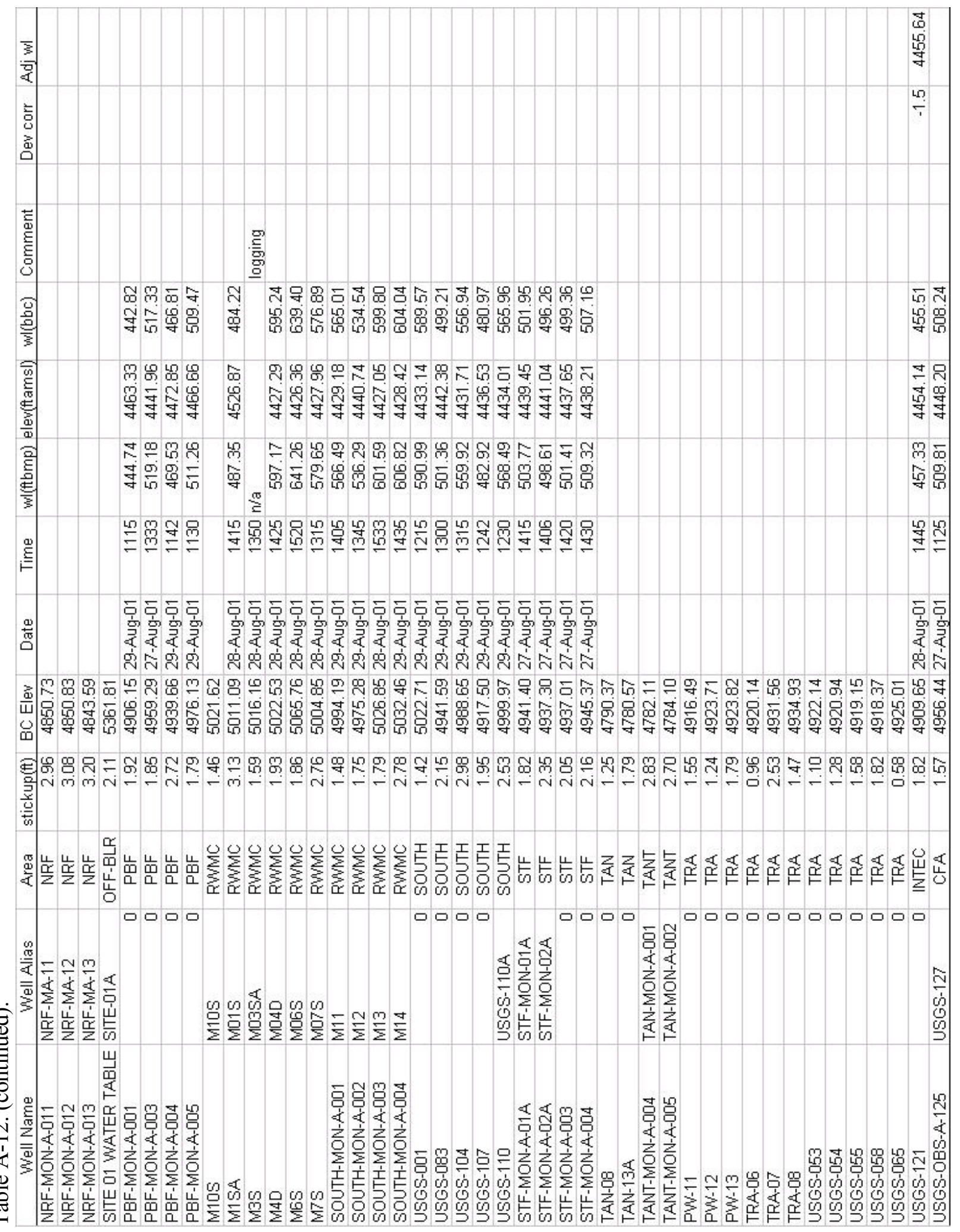

